\title{
Vernet av økonomiske rettigheter mot regulering under Grl. §§ 97 og 105 og EMK P1-1
}

\section{Sammendrag}

Artikkelen behandler det konstitusjonelle eller semi-konstitusjonelle vernet av $\varnothing$ konomiske rettigheter mot etterfølgende regulering under henholdsvis Grl. §§ 97 og 105 og Den europeiske menneskerettighetskonvensjon, første tilleggsprotokoll, artikkel 1. Et hovedsynspunkt i artikkelen er at det grunnlovmessige reguleringsvernet grunnleggende sett bygger på en presumsjonsbasert avveiningsnorm med to motstående utgangspunkter, som i grove trekk samsvarer med utgangspunktene under EMK P1-1. Et grunnleggende utgangspunkt er at $\varnothing$ konomiske rettigheter kan reguleres med virkning for fremtiden. I dette ligger en normativ føring for avveiningsnormen som tilsier en høy terskel for rettighetsvernet - etter Grl. §§ 97 og 105 gjerne formulert som et krav til at inngrepet må være "klart urimelig eller urettferdig» eller utfra en helhetsvurdering er "sterkt urimelig.» Artikkelen viser imidlertid at dette utgangspunktet ikke gir noen egnet formulering av vurderingstemaet $\mathrm{i}$ alle tilfeller av omfattende rettighetsinngrep. Både under EMK P1-1 og Grl. §§ 97 og 105 er det holdepunkter for at etterfølgende regulering som i vesentlig grad griper inn i og rokker ved berettigete forventninger og innrettelse aktualiserer et skjerpet forholdsmessighetskrav. Under norsk rett kan dette i samsvar med $\mathrm{H} \varnothing$ yesteretts nyere praksis formuleres som et krav til «sterke samfunnsmessige hensyn.»

Stikkord: Regulering, eiendomsvern, rettighetsvern, berettigete forventninger, tilbakevirkning, ekspropriasjon, avståelse

1. Innledning

2. Grunnelementene i rettighetsvernet under Grl. §§ 97 og 105 og EMK P1-1 .................. 5

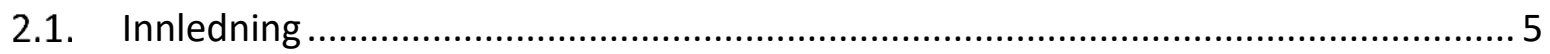

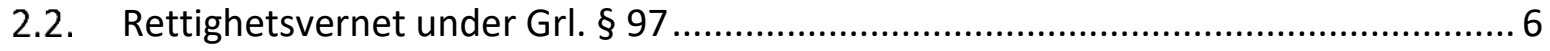

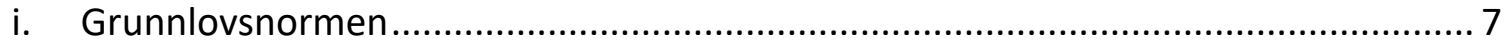

ii. Kravet til at det må foreligge en beskyttet rettighet.............................................. 9

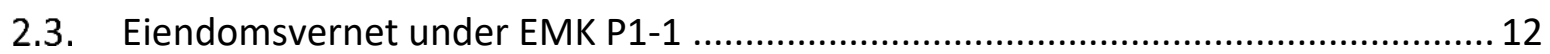

i. Hovedelementene i eiendomsvernet - de tre «reglene» ...................................... 12

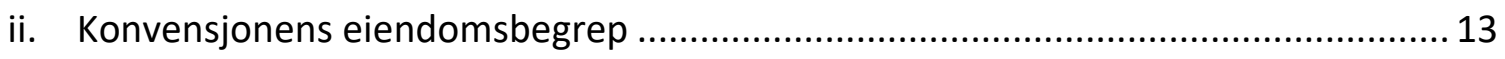

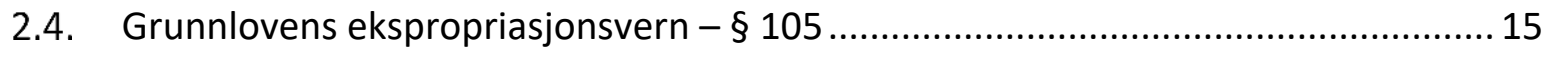

i. Beskyttelsen mot å måtte avgi eiendom ............................................................... 15

ii. Hva som utgjør «eiendom» under Grl. § 105 ................................................... 17 
2.5. Oppsummering og ansats.

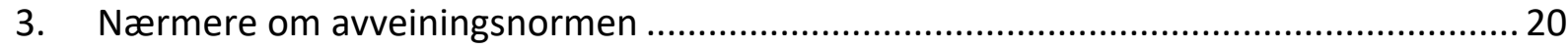

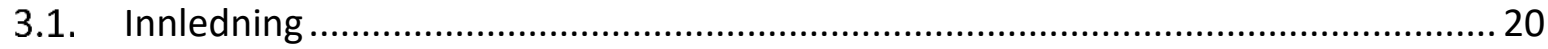

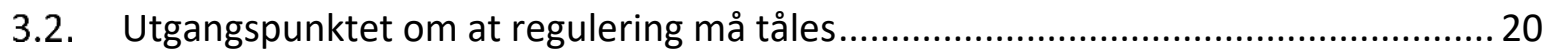

3.3. Nærmere om unntaket for klart uforholdsmessige inngrep ................................. 25

i. Grl. § 97 - «klart urimelig eller urettferdig»-normen ............................................ 25

ii. Rådighetsinnskrenkninger under Grl. § 105 - «sterkt urimelig»-kriteriet ................. 27

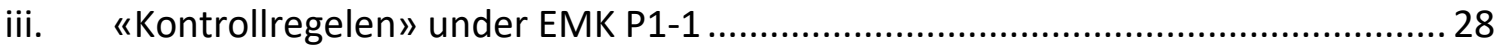

3.4. Gjelder «sterke samfunnsmessige hensyn»-normen rettigheter? .......................... 31

4. Betydningen av at det gripes inn i en berettiget forventning eller særrett ................... 35

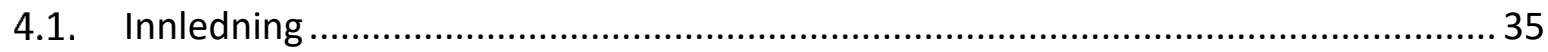

4.2. Berettigede forventninger og særretter under Grl. § 97 ...................................... 36

i. Betydningen av at det foreligger eller ikke foreligger en berettiget forventning..... 36

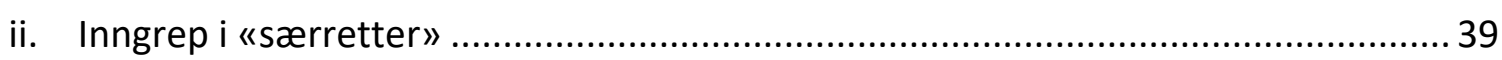

iii. Nærmere om grunnlaget for en avståelsesregel ved tilsidesettelse av berettigede forventninger og særretter under Grl. § 97 ............................................................ 41

4.3. Forholdet mellom delvis avståelse og rådighetsinnskrenkning under Grl. § $105 \ldots . . .42$

4.4. Nærmere om betydningen av hvor vesentlig eller omfattende inngrepet er ......... 46

5. Konklusjon

\section{Innledning}

Temaet for denne artikkelen er det konstitusjonelle vernet av eksisterende, $\varnothing$ konomiske rettigheter og rettsposisjoner mot etterfølgende lovregulering. ${ }^{1}$ Tradisjonelt har vernet av andre rettsposisjoner enn eiendom blitt antatt å følge av tilbakevirkningsforbudet i Grl. § $97,{ }^{2}$ mens regulering av eiendom - såkalte rådighetsinnskrenkninger - primært har blitt

\footnotetext{
${ }^{1}$ Med regulering mener jeg her lover og forskrifter som gir generelle regler med virkning for eksisterende rettsposisjoner. Individuelle vedtak som griper inn i eksisterende rettigheter faller dermed utenfor temaet for fremstillingen, uten at noen skarp avgrensning er tilsiktet. For eksempel kan det tenkes at et aktuelt inngrep skjer gjennom enkeltvedtak, men at vedtaket bygger på en ny og mer omfattende hjemmel for slike inngrep. Skillet mellom forskrifter og enkeltvedtak reiser egne spørsmål som ikke behandles videre her, se for eksempel Jan Fridtjof Bernt og Ørnulf Rasmussen, Frihagens forvaltningsrett Bind 1, 2. utg. Bergen 2010, s. 173-174. Se også HR-2018-1258-A, avsnitt 89 flg. Jeg går heller ikke inn på de særspørsmål som knytter seg til tilbakevirkende forskrifter, se i denne forbindelse forvaltningsloven § 39 og Rt-1992-182.

2 Se for eksempel Ragnar Knoph, Rettslige standarder, Oslo 1948, s. 103-119; og Frede Castberg, Norges statsforfatning II, 3. utg. Oslo 1964, s. 197-200.
} 
vurdert under Grl. § 105. ${ }^{3}$ Likevel er det et betydelig samspill mellom de to bestemmelsene. ${ }^{4}$ En fremstilling av dette temaet i dag kan heller ikke unngå å forholde seg til eiendomsvernet etter Den europeiske menneskerettighetskonvensjon, første tilleggsprotokoll, artikkel 1 (P1-1). ${ }^{5}$ I lys av senere høyesterettspraksis er det et relevant spørsmål om P1-1, i alle fall på visse områder, i realiteten har overtatt som det primære «konstitusjonelle» vern av $\varnothing$ konomiske rettigheter i norsk rett. ${ }^{6}$ En slik tendens er ikke uproblematisk i lys av vår særegne norske rettstradisjon på dette området. ${ }^{7}$ Riktignok har EMK status som intern norsk rett og skal anvendes som det av norske domstoler. Likevel er det primært gjennom tolkningen av Grunnloven at norske domstoler og Høyesterett kan sette sitt eget selvstendige preg på en rettsutvikling som, i dagens overnasjonale virkelighet, i økende grad foregår gjennom dialog mellom nasjonale domstoler og EMD. ${ }^{8}$ Disse utviklingstrekkene kan tilsi at enkelte av våre tilvante forestillinger tas opp til ny vurdering.

Hovedfokuset i det følgende er rettighetsvernet mot etterfølgende regulering under Grl. §§ 97 og 105, men på enkelte sentrale punkter ser jeg også til praksis under EMK P1-1. Artikkelen tar i lys av dette til orde for en mer prinsipporientert tilnærming til spørsmål som det i moderne, norsk tradisjon, inspirert av den såkalte standardteorien, har vært vanlig å se som nokså åpne rimelighets- eller rettferdighetsvurderinger. ${ }^{9}$

Utgangspunktet om at lovgiver må ha stor grad av frihet for å kunne ivareta allmenne hensyn til enhver tid står sterkt i norsk rettstradisjon. ${ }^{10}$ Men særlig i lys av overnasjonale utviklingstrekk med både $\varnothing k t$ rettighetsfokus og utstrakt domstolsprøving av

\footnotetext{
${ }^{3}$ Castberg (1964) s. 252; se også Jørgen Aall, Rettsstat og menneskerettigheter, 5. utg., Bergen 2018, s. 345349; Johs. Andenæs og Arne Fliflet, Statsforfatningen i Norge, 11. utg., Oslo 2017 s. 556; Eivind Smith, Konstitusjonelt demokrati, 4. utg., Oslo 2009, s. 407-408.

${ }^{4}$ Knoph (1948) s. 103 flg.; Castberg (1964) s. 237-238.

${ }^{5}$ Protokollen er gjort til norsk lov gjennom Lov 21. mai 1999 nr. 30 (Menneskerettsloven). Forrangsprinsippet innebærer at bestemmelsen langt på vei i praksis fungerer som et konstitusjonelt vern, selv om det må anses på det rene at bestemmelsen ikke formelt har konstitusjonell rang selv etter vedtagelsen av Grl. § 92 og dermed vil kunne fravikes ved lov, jf. HR-2016-2554-P. Se særlig Aall (2018) s. 328-357 for en samlet fremstilling av Grl. §§ 97 og 105 og EMK P1-1.

${ }^{6}$ Se for eksempel HR-2019-1206-A, HR-2018-1258-A, HR-2016-304-S og Rt-2015-421. Og se også Benedikte Moltumyr Høgberg, «Betydningen av internasjonale rettskilder i norsk statsforfatningsrett» i Andreas Føllesdal, Morten Ruud og Geir Ulfstein (red.), Menneskerettighetene og Norge, Oslo 2017, s. 215-227, på s. 222.

${ }^{7} \mathrm{Grl}$. §§ 97 og 105 har tradisjonelt fungert som det viktigste utgangspunkt for domstolenes prøvingsrett overfor lover, som nå er forankret i Grl. § 89, se for eksempel Arnulf Tverberg, «§ 89» i Ola Mestad og Dag Michalsen, Grunnloven: Historisk kommentarutgave, Oslo 2021 (under publisering).

${ }^{8}$ Se generelt Matti Pellonpää, «Dialog mellom Den europeiske menneskerettsdomstol og nasjonale domstoler» Det 40. nordiske juristmøte i Oslo 2014, tilgjengelig på http://nordiskjurist.org/wpcontent/uploads/2014/07/referent19.pdf; jf. også Arnfinn Bårdsen, foredrag på Ryssdalseminaret 30. november 2017, tilgjengelig på https://www.domstol.no/globalassets/upload/hret/dokumenter/taler-ogartikler/ryssdal-seminaret-2017.pdf.

${ }^{9}$ Se for viktige teoretiske formuleringer av dette utgangspunktet særlig Knoph (1938) s. 65 flg.; og med hensyn til Grl. § 105 særlig Carl August Fleischer, Grunnlovens grenser for lovregulert fastsetting av erstatning ved ekspropriasjon, særlig ved verdistigning som ikke skyldes grunneierens innsats, Oslo 1968, s. $204 \mathrm{flg}$.

${ }^{10}$ Se særlig betraktningene rundt dette hos Fleischer (1968) s. $221 \mathrm{flg}$.
} 
myndighetsut $\varnothing v e l s e$ for å beskytte $\varnothing$ konomiske interesser, ${ }^{11}$ kan det være grunn til å problematisere den fortsatte berettigelsen av en så åpen og fleksibel tilnærming til rettighetsvernet som har vært vanlig i norsk rett. ${ }^{12}$

Lovgivningens frihet til å gripe inn i og regulere privates handlinger og virksomhet, og derunder gripe inn i private interesser og rettigheter der det er $n \varnothing d v e n d i g$ av hensyn til allmenne interesser, er likevel så dypt rotfestet i vårt demokratiske og konstitusjonelle system at det ikke i seg selv er noen grunn til å utfordre dette som et grunnleggende normativt utgangspunkt også for grunnlovsvernet av rettigheter. Spørsmålet som skal drøftes i det følgende er derimot om det grunnlovmessige rettighetsvernet kan og bør formuleres gjennom noe mer nyanserte og presise vurderingstemaer enn det standardteoritilnærmingen har skapt tradisjon for i norsk rett. Jeg skal i denne forbindelse konsentrere meg om selve grunnlovsnormen; hva som er kriteriet for å avgjøre om et inngrep er i strid med rettighetsvernet. ${ }^{13}$

Det er ingen nødvendig motsetning mellom et utgangspunkt om at regulering må tåles og et utgangspunkt om at grunnleggende hensyn til trygghet og forutsigbarhet for etablerte rettsposisjoner må ivaretas. Primært handler dette, her som på mange andre områder, om en avveining. ${ }^{14}$ Det sentrale spørsmålet blir som vi skal se hvor langt domstolene kan og bør gå i å prøve forholdsmessigheten av inngrep i ulike rettighetsposisjoner. ${ }^{15}$

Følgende utgangspunkter er antagelig forholdsvis ukontroversielle med hensyn til hvordan vi bør tenke om dette spørsmålet: For det første; eksisterende virksomhet, rettigheter og eiendom kan reguleres gjennom lov. ${ }^{16}$ Forventninger om fremtidig utnyttelse er som

\footnotetext{
11 Jf. om denne utviklingen blant annet Hans Petter Graver, «Dømmer Høyesterett i siste instans?» Jussens Venner, 2002, s. 263-281; Inge Lorange Backer, "Lovgivere og domstoler ved begynnelsen av det 21. århundre» Jussens Venner, 2006, s. 248-266; og se også Jørn Øyrehagen Sunde, Høgsteretts historie 1965-2015, Bergen 2015, s. $395 \mathrm{flg}$.

${ }^{12}$ Se også de kritiske betraktningene mot å se grunnlovsvernet som en ren rimelighets- eller rettferdighetsstandard hos Benedikte Moltumyr Høgberg, Forbud mot tilbakevirkende lover, Oslo 2010, s. 322; og Jens Edvin A. Skoghøy, «Forbud mot tilbakevirkende lovgivning» Lov og Rett, 2011, s. 255-282, på s. 272273.

${ }^{13}$ Et annet spørsmål som jeg ikke går inn på i det følgende gjelder virkningene av dette, og der det er aktuelt, hvilken erstatning som kan kreves, se om dette for eksempel Høgberg (2010) s. 436 flg.

${ }^{14} \mathrm{Om}$ utviklingen og betydningen av forholdsmessighetsvurderinger som et verkt $\varnothing$ y for domstolsprøving i ulike land, se David Beatty, The Ultimate Rule of Law, Oxford 2004, særlig s. 159 flg.; og om forholdsmessighetsvurderinger i norsk stats- og forvaltningsrett, Tor-Inge Harbo, «Forholdsmessighet i kontekst: forholdsmessighetsvurderinger i norsk forvaltnings- og forfatningsrett» Lov og Rett, 2015, s. 513-535. ${ }^{15}$ Både ved domstolsprøving på grunnlag av Grunnloven og EMK er dette et spørsmål om graden av prøving eller prøvingsintensitet, jf. nærmere nedenfor pkt. 3.2 om den tredelte differensieringen av grunnlovsprøving som ble introdusert i Rt-1976-1. Ved fortolkningen av EMK anvendes i henhold til EMDs praksis en skjønnsmargin, men det er ikke dermed gitt at det er og bør være sammenfall mellom den skjønnsmargin EMD anvender og norske (nasjonale) domstolers prøvingsintensitet, se nærmere Håkon Christian Nyhus, «Høyesterett og EMD - samme skjønnsmargin?» Lov og Rett, 2016, s. 364-390.

${ }^{16} \mathrm{Jf}$. rett og slett utgangspunktet om Stortingets lovgivningsmyndighet etter Grl. § $75 \mathrm{a}$ ).
} 
utgangspunkt ikke beskyttet i større grad enn den individuelle handlefrihet. ${ }^{17}$ Selv om en bestemt utnyttelse, handling eller virksomhet er lovlig og mulig i dag, betyr ikke det at man har noen garanti mot fremtidige reguleringer som innskrenker handlefriheten. Derfor er normalt heller ikke slik regulering noe som fordrer en særlig omfattende eller intensiv forholdsmessighetsprøving. Inngrep som er særlig omfattende, eller som rokker ved klare og definerte rettsposisjoner og berettiget innrettelse, aktualiserer derimot i st $\varnothing$ rre grad hensynet til rettighetsvern, trygghet og forutberegnelighet. Dette kan tilsi skjerpede krav til forholdsmessighet og en mer intensiv domstolsprøving. Heller ikke dette kan vel anses særlig kontroversielt, men som vi skal se kan det formuleres rettslig på litt ulike måter.

Artikkelens hovedkonklusjon er at rettigheters vern mot regulatoriske inngrep kan formuleres som en presumsjonsbasert forholdsmessighetsnorm med to motstående utgangspunkter. Det første utgangspunktet er at alle rettsposisjoner kan reguleres med virkning for fremtiden, med et unntak for klart uforholdsmessige inngrep. I praksis innebærer dette et sterkt utgangspunkt om at regulering må tåles. Det andre og motstående utgangspunktet er at visse omfattende inngrep i etablerte rettsposisjoner og rettigheter aktualiserer et skjerpet forholdsmessighetskrav. I lys av nyere høyesterettspraksis, men blant annet i strid med flertallets syn i den såkalte strukturkvotedommen, hevder jeg at dette kan formuleres som et krav til «sterke samfunnsmessige hensyn. ${ }^{18} \mathrm{Et}$ av artikkelens hovedformål er å analysere nærmere hva som skal til for at dette skjerpede forholdsmessighetskravet aktualiseres. Som vi skal se kan et egnet utgangspunkt ofte være et begrep om berettigete forventninger, som igjen ofte vil kunne ses som et spørsmål om i hvilken grad det foreligger konkret og velbegrunnet forutsatte virkninger av fortidige disposisjoner og handlinger.

Artikkelen har tre hoveddeler. Først ser jeg på grunnelementene i rettighetsvernet under henholdsvis Grunnloven og EMK (punkt 2). Deretter ser jeg nærmere på vurderingstemaene under de parallelle avveiningsnormene som utgjør rettighetsvernet ved regulatoriske inngrep (punkt 3). Endelig drøfter jeg betydningen av at det ved lovgivning som har et regulerende siktemål gripes inn i en berettiget forventning eller særrett (punkt 4). Jeg avslutter med en oppsummering og konklusjon (punkt 5).

\section{Grunnelementene i rettighetsvernet under Grl. §§ 97 og 105 og EMK P1-1}

\subsection{Innledning}

Grunnloven §§97 og 105 og EMK P1-1 er, som vi skal komme tilbake til nedenfor, ulike regler med til dels ulike formål. Likevel har bestemmelsene til felles at de oppstiller et vern av etablerte rettigheter mot statlige inngrep. Særlig EMK P1-1 har vært gjenstand for en

\footnotetext{
${ }^{17}$ Fleischer (1968) s. 205-206; og jf. også mer generelt om forholdet mellom «property-limitation rules» som knytter seg til innskrenkning av eiendomsrådighet som sådan, og «property-independent prohibitions» som innskrenker den alminnelige handlefrihet, J. W. Harris, Property \& Justice, Oxford 2001, s. 40-41.

${ }^{18}$ De to sentrale dommene er Rt-2006-293 (Arves trafikkskole) og Rt-2010-143 (rederiskatt). Flertallets syn i Rt2013-1345 (strukturkvote) var derimot at regulering av rettigheter for fremtiden alltid må vurderes under «klart urimelig eller urettferdig»-normen.
} 
omfattende rettsutvikling, der visse grunnleggende elementer av et overordnet rettighetsvern avtegner seg. Slik både Grl. §§ 97 og 105 er blitt tolket av Høyesterett de senere år, finner vi imidlertid igjen mange av de samme grunnelementene som under P1-1.

Et prinsipielt spørsmål er hvilken betydning eiendomsvernet under EMK bør ha for grunnlovsvernet. Menneskerettighetsdomstolens tolkning av P1-1 kan naturligvis ikke i seg selv være avgjørende for grunnlovstolkningen. ${ }^{19}$ Det må likevel anses som et generelt hensyn at rettighetsbestemmelsene i Grunnloven ikke bør gi svakere vern enn det som følger av EMK. ${ }^{20}$ Selv om dette hensynet nok står sterkest for de grunnlovsbestemmelsene som er direkte inspirert av EMK bør det også være et relevant hensyn ved tolkningen av Grl. $\S \S 97$ og 105. En tolkning av Grunnlovens økonomiske rettighetsvern som innrettes mot et lavere beskyttelsesnivå enn det som følger av P1-1 vil i realiteten medføre at grunnlovsvernet mister mye av sin praktiske betydning. Norske domstoler og Høyesterett vil dermed miste en viktig forankring for selv å kunne bidra med selvstendig rettsutvikling på dette området, noe som igjen vil svekke muligheten for reell dialog med EMD. ${ }^{21} \AA$ akseptere at den særegne norske rettstradisjonen på dette området kapitulerer overfor en rettsutvikling som foregår i Strasbourg bør sitte langt inne.

Særlig der bestemmelsene oppstiller sammenfallende vurderingstemaer tilsier dette at EMDs praksis under P1-1 tillegges vekt også ved tolkningen av Grl. §§ 97 og 105. Som vi skal se er det særlig vurderingstemaene under Grl. § 97 og P1-1 som er sammenfallende, og som utgjør de sentrale komponentene i rettighetsvernet mot regulering. ${ }^{22}$ Men under norsk rett har dette har også en viktig side til Grl. § 105. Stikkord er som vi skal se nedenfor et bestemt rettighetsbegrep, en skillelinje mellom regulering og avståelse, og et overordnet krav til forholdsmessighet.

I det følgende gjennomgår jeg først grunntrekkene av rettighetsvernet under Grl. § 97 (punkt 2.2), før jeg sammenligner dette med eiendomsvernet under EMK P1-1 (punkt 2.3) og endelig ser nærmere på det mer absolutte vernet mot å måtte avgi eiendom som følger av Grl. § 105 (punkt 2.4). På grunnlag av denne sammenstillingen reflekterer jeg så litt nærmere rundt noen prinsipielle utgangspunkter for artikkelens resterende deler (punkt 2.5).

\subsection{Rettighetsvernet under Grl. § 97}

Grl. § 97 beskytter ikke primært rettigheter. Opprinnelig var kanskje strafferetten tenkt som bestemmelsens primære virkeområde, og forbudet mot tilbakevirkende straffelover utgjør fortsatt bestemmelsens harde kjerne, men den har også et videre nedslagsfelt. ${ }^{23}$

\footnotetext{
${ }^{19}$ Høgberg (2017) s. 221-222.

${ }^{20}$ Se generelt Arnfinn Bårdsen, «Norges Høyesterett, Grunnloven og menneskerettighetene» i Andreas Føllesdal, Morten Ruud og Geir Ulfstein (red.), Menneskerettighetene og Norge, Universitetsforlaget 2017 , s. 63-90, på s. 75-76. Og se også Anine Kierulf, «Er internasjonale menneskerettigheter en relevant rettskilde ved grunnlovstolkning?» Retfærd, $2011 \mathrm{nr} .1$, s. 23-48.

${ }^{21}$ Bårdsen (2017) s. 77.

22 Jf. slik dommer Skoghøys dissensvotum i Rt-2013-1345, avsnitt 232 og 240, se også førstvoterende med tilslutning fra flertallet, særlig avsnitt 149 og 155.

${ }^{23}$ Andenæs og Fliflet (2017) s. 570 flg., og jf. også Smith (2009) s. 413 flg. som sterkt betoner forbudet mot tilbakevirkende straffelover som bestemmelsens hovedformål.
} 
Bestemmelsens viktigste formål er å beskytte hensynet til forutberegnelighet, og den enkeltes mulighet til å forutsi rettsvirkningene av sine handlinger og disposisjoner. ${ }^{24} \mathrm{Når}$ inngrep i rettigheter aktualiserer tilbakevirkningsforbudet er det fordi rettigheter enten er et resultat av, eller gir grunnlag for, bestemte handlinger, disposisjoner eller innrettelse. ${ }^{25}$ Man kan imidlertid også se det slik at rettigheter gir et generelt grunnlag for forventninger om fremtiden - det er noe av poenget med en rettighet. Hensynene som ligger under Grl. § 97 tilsier dermed at det ikke bør gripes inn i etablerte rettigheter vilkårlig og uten god grunn. Samtidig er det hvor omfattende og direkte det gripes inn overfor fortidige disposisjoner og handlinger som avgjør styrken av rettighetsvernet, eller som Høyesterett har formulert det, «hvor sterkt tilbakevirkningselementet er». ${ }^{26}$

Slik Høyesterett i den senere tid har tolket bestemmelsen må det skilles mellom to spørsmål; hvilken grunnlovsnorm som kommer til anvendelse (pkt. i), og hvilke rettsposisjoner eller rettigheter som aktualiserer kravet på beskyttelse (pkt. ii).

\section{i. Grunnlovsnormen}

Grl. § 97 har en lang og broket tolkningshistorie og det er nok fortsatt ikke full enighet om terminologien, ${ }^{27}$ men en viktig distinksjon går mellom den såkalte egentlige og uegentlige tilbakevirkning. ${ }^{28}$ Med egentlig tilbakevirkning menes at det knyttes nye og tyngende virkninger, typisk straff, til eldre handlinger. Med uegentlig tilbakevirkning menes derimot at en etablert rettsposisjon, eller rettighet, reguleres for fremtiden. Mens det antas å gjelde et nær absolutt forbud mot egentlig tilbakevirkning, ${ }^{29}$ har utgangspunktet ved rettighetsinngrep som virker fremover $\mathrm{i}$ tid, etter Borthen-dommen blitt formulert som at det kun er de «klart urimelige eller urettferdige» inngrep som rammes. ${ }^{30}$ Dette forutsetter i samsvar med nyere rettspraksis en momentbasert helhetsvurdering, der utgangspunktet er

\footnotetext{
${ }^{24}$ Knoph (1938) s. 78; Castberg (1964) s. 189; og Andenæs og Fliflet (2017) s. 575-576. Særlig standardteoriens forkjempere fremhever likevel at dette hensynet i tilknytning til rettigheter ikke går lenger enn å beskytte mot overgrep og vilkårlighet fra statsmaktens side, se Knoph (1938) s. 65 flg., og Carl August Fleischer, «Grunnlovens § 97» Jussens Venner, 1975, s. 187-190.

${ }^{25}$ Castberg (1964) s. 187-188

${ }^{26}$ HR-2016-389-A avsnitt 76, og Rt-2010-143 avsnitt 153.

${ }^{27}$ Se om tolkningshistorien særlig Høgberg (2010) s. 251 flg.; og også Benedikte Moltumyr Høgberg, ‘Hvordan samfunnet har påvirket tolkningen av Grunnloven §§ 97 og 105' i Eirik Holmøyvik (red.), Tolkingar av Grunnlova: Om forfatningsutviklinga 1814-2014, Oslo 2013, s. 368-403.

${ }^{28}$ Terminologien egentlig/uegentlig tilbakevirkning har opphav hos Fleischer som mente at det i realiteten var tale om to ulike rettsregler, der det kun var forbudet mot den egentlige tilbakevirkning som fulgte direkte av Grl. § 97, jf. Fleischer (1975) særlig på s. 190 flg. Distinksjonen samsvarer imidlertid i all hovedsak med et skille man også tidligere gjorde, før den nåværende terminologien fikk fotfeste, mellom handlinger og rettigheter, se særlig Frede Castberg, Grunnlovens forbud mot å gi lover tilbakevirkende kraft, Oslo 1919, s. 51 og s. 57 flg. Heller ikke i eldre tider synes det å ha vært noen reell uenighet om dette skillet, se for eksempel Castberg (1919) s. 115 flg.; Bredo Morgenstierne, Lærebog i den norske Statsforfatningsret, 2. utg., Oslo 1909, s. 688 flg.; og T. H. Aschehoug, Norges nuværende statsforfatning, Oslo 1893, s. 280. Se også Hans Christian Bugge, «Grunnloven § 97: En oversikt over teori og nyere rettspraksis» Jussens Venner 1999 s. 65-101, på s. 69; og Høgberg (2010) s. 265 flg.

${ }^{29}$ Rt-2010-1445.

${ }^{30}$ Rt-1996-1415 (Borthen). Kriteriet er senere anvendt av Høyesterett i Rt-1996-1440, Rt-2001-762, Rt-2006262; Rt-2013-1345 (flertallet) og HR-2016-389-A (Carl I. Hagen).
} 
at lovgiver har stort spillerom, men hvor det også skal foretas en reell interesseavveining der den private interessen og dens behov for beskyttelse hensyntas. ${ }^{31}$

Samtidig har $\mathrm{H} \varnothing$ yesterett ved et par anledninger anvendt en alternativ norm, som indikerer et sterkere utgangspunkt om beskyttelse enn «klart urimelig eller urettferdig»-normen, men uten at vernet er absolutt. I plenumsdommen i den såkalte Arves trafikkskole la flertallet til grunn at pålegget om avgift på allerede foretatte disposisjoner måtte anses som grunnlovsstridig tilbakevirkning, med mindre det var begrunnet $\mathrm{i}$ «sterke samfunnsmessige hensyn. ${ }^{32}$ Dette ble fulgt opp i Rederiskatt-dommen. ${ }^{33}$ Saken gjaldt omlegging av rederiskatteordningen, som brakte til opphør en betinget skattefrihet, eller skattekreditt, knyttet til opptjente inntekter under den gamle ordningen. Et knapt flertall av Høyesterett i plenum kom også her til at omleggingen var grunnlovsstridig fordi det ikke forelå «sterke samfunnsmessige hensyn.» Ingen av dommene gjorde det imidlertid helt klart om det var graden av inngrep i etablerte rettigheter, eller alene det at det ble knyttet nye byrder til eldre handlinger, som aktualiserte et skjerpet forholdsmessighetskrav. I strukturkvotedommen, også denne avsagt i plenum, fant imidlertid et knapt flertall at inngrep i rettigheter alltid aktiverer «klart urimelig eller urettferdig»-normen. Mindretallet mente derimot at inngrepet aktualiserte "sterke samfunnsmessige hensyn»-normen fordi det var tale om tillitsbasert innrettelse som var særlig beskyttelsesverdig. ${ }^{34}$

I andre sammenhenger og senere har det vært tatt til orde for at det ikke nødvendigvis spiller så stor rolle hvordan utgangspunktet angis, siden den grunnleggende normen er en helhetlig interesseavveining, der utgangspunktene mer er ytterpunkter på en glideskala enn ulike prinsipper. ${ }^{35}$ Det er heller ikke alltid at interesseavveiningen fremstår særlig fremtredende. ${ }^{36}$ I den foreløpig siste dommen som har tatt stilling til rettighetsvernet under Grl. § 97 oppsummerte Høyesterett (riktignok i avdeling) utgangspunktet som følger:

«[K]jernespørsmålet er hvor sterkt tilbakevirkningselementet er. Hvis loven direkte knytter tyngende rettsvirkninger til tidligere hendelser, er loven som hovedregel grunnlovsstridig. Gir loven derimot bare regler om hvordan en allerede etablert posisjon skal utøves, er hovedregelen den motsatte. I de sistnevnte tilfellene har lovgiveren et betydelig spillerom, se avsnitt 94 i strukturkvotedommen. Det er en glidende overgang mellom disse ytterpunktene. I rederiskattedommen omtales dette som «overgangsformer», mens det $\mathrm{i}$

\footnotetext{
${ }^{31}$ Se særlig Rt-2013-1345 og HR-2016-389-A. Og se også slik Høgberg (2010) s. 317 flg. Og jf. nærmere nedenfor pkt. 3.3.

32 Rt-2006-293.

33 Rt-2010-1343.

${ }^{34}$ Rt-2013-1345.

${ }^{35}$ Se mindretallet i Rt-2006-293 og slik tilsynelatende også Benedicte Moltumyr Høgberg, «Grunnloven § 97 etter plenumsdommen i Rt-2010-143 (Rederiskattesaken)» Tidsskrift for rettsvitenskap, 2010, s. 694-744, på s. 711.

${ }^{36}$ I Rt-2006-262 la for eksempel Høyesterett til grunn at inngrepet rammet enken hardt, uten at det synes å ha blitt tillagt særlig betydning. Inntrykket man får er vel at retten i realiteten la til grunn at den aktuelle rettigheten ikke var spesielt beskyttelsesverdig, se særlig avsnitt 98-103.
} 
strukturkvotedommen fremheves at «Borthen-normen» er relativ, fleksibel og skjønnsmessig.

Jeg konstaterer videre at det uavhengig av normvalg må skje en avveining mellom de vernede interesser på den ene siden, og de samfunnsmessige hensynene på den annen. Vurderingen må skje konkret for dem som er parter i saken, men det må kunne tas hensyn til helheten ved lovreguleringen, se avsnitt 155 i rederiskattedommen. Ved vurderingen har det betydning hvilke rettigheter eller posisjoner inngrepet gjelder, hvilket grunnlag den enkelte eller en gruppe har for sine forventninger, om inngrepet er plutselig og betydelig, og om fordelingen av byrdene rammer den enkelte eller en gruppe særlig hardt, jf. Borthendommen og strukturkvotedommen. De samfunnsmessige hensynene må holdes opp mot dette. $)^{37}$

Høyesterett holdt det uttrykkelig åpent om dette kunne tilsi et strengere krav til forholdsmessighet ved inngrep i særlig beskyttelsesverdige rettsposisjoner, som statspensjoner, siden tilbakevirkningselementet i den aktuelle saken uansett ikke var særlig fremtredende. ${ }^{38}$ Dette skal vi komme tilbake til nedenfor. ${ }^{39}$

ii. Kravet til at det må foreligge en beskyttet rettighet

Under Grl. § 105 og EMK P1-1 må det for at rettighetsvernet skal aktualiseres foreligge en beskyttet rettighet. Det er kun «eiendom» som er beskyttet. Det er ikke like opplagt at den fleksible avveiningsnormen under Grl. § 97 krever noe lignende rettighetsbegrep. ${ }^{40} \mathrm{Hvor}$ beskyttelsesverdig den enkelte rettsposisjon er inngår jo uansett som et element $\mathrm{i}$ avveiningen. ${ }^{41}$

Samtidig tilsier prinsipielle hensyn, herunder et hensyn til konsekvens i rettssystemet, at det må gjelde en kvalifikasjonsterskel for hva som utgjør beskyttede rettsposisjoner også under Grl. § 97. ${ }^{42}$ Et nokså selvsagt utgangspunkt er at det ikke gjelder noe alminnelig vern mot at noen påføres tap som følge av lovendringer eller annen myndighetsut $\varnothing v e l s e$. Også i forholdet mellom privatpersoner er det slik at As handlinger kan påføre B tap uten at det medfører ansvar for A. For at ansvar skal inntre må As handlinger utgjøre en integritetskrenkelse, eller angripe noe som kan anses som en erstatningsrettslig vernet interesse hos B - det må foreligge en «rettighetskrenkelse». ${ }^{43}$ Der A skuffer en berettiget

\footnotetext{
${ }^{37}$ HR-2016-389-A avsnitt 76-77.

38 Ibid. avsnitt 78 og 86-87.

${ }^{39}$ Særlig pkt. 3.4 og 4.

${ }^{40}$ Det gamle synspunkt som ble hevdet av Aschehoug og Morgenstierne med flere var at det avgjørende også for beskyttelsen under Grl. § 97 var om man hadde en såkalt velervervet rettighet. Et av standardteoriens viktigste bidrag var derimot at man så også dette som en funksjon av rettferdsstandarden, jf. Knoph (1938) s. 86 flg., og se også Per Augdahl, «Noen bemerkninger om grunnlovens § 97 og § 105», Rt-1935-33.

41 Jf. forutsetningsvis i denne retningen Rt-2006-262, særlig avsnitt 98-103. Heller ikke Høgberg (2010), særlig s. 171 flg., synes å se dette som noe eget vilkår, utover det alminnelige kravet om at tilbakevirkningen må være til skade.

${ }^{42}$ Se i denne retning også Bugge (1999) s. 80 flg.

${ }^{43}$ Viggo Hagstrøm og Are Stenvik, Erstatningsrett, Oslo 2015 s. 48 flg.
} 
forventning han har skapt hos B vil det også kunne gi grunnlag for ansvar. ${ }^{44}$ Man kan se det slik at det i så fall nettopp er skapt en beskyttet interesse - en «rettighet» - i kraft av den berettigede forventning. Lignende betraktninger kan også gjøres i tilknytning til ny eller endret lovgivning som volder noen tap. For at spørsmålet om mulig ansvar for det offentlige i det hele tatt skal oppstå må det foreligge et inngrep i noe som kan anses som en rettslig beskyttet interesse eller rettighet hos den private part. ${ }^{45}$

Høyesterett har i flere nyere saker forutsatt eller innfortolket et slikt kvalifiserende rettighetsbegrep under Grl. § 97. Et av punktene det var uenighet om i Borthen-dommen var nettopp om pensjonsrettighetene etter sin art var beskyttet av Grl. § 97. Tidligere var det antatt at primært statspensjoner hadde grunnlovsvern. Tilknytningen til ansettelsesforholdet i staten innebar et avtalerettslig element og status som en «økonomisk særrett. ${ }^{46}$ For pensjonsrettigheter som mer hadde karakter av «sosial trygdeytelse» synes derimot forutsetningen å ha vært at disse ikke hadde grunnlovsvern. ${ }^{47}$ I tråd med dette mente mindretallet i Borthen-dommen, anført av annenvoterende dommer Tjomsland, at siden det var tale om «krav som bygger direkte på lovens bestemmelser» var det ikke «plass for noen prøvelse etter Grunnloven $\S 97$ av senere lovendringer. ${ }^{48}$ Synspunktet var altså at pensjonsrettighetene fulgte direkte av loven og dermed ikke hadde fått karakter av beskyttet rettighet. Førstvoterende dommer Scheis syn, som vant tilslutning fra flertallet, var derimot at pensjonsrettighetene etter sin art var beskyttet, noe han begrunnet $i$ pensjonssystemets formål:

«Pensjonssystemet er etablert for at folk kan og skal innrette seg etter det. Det er kommet i stedet for tidligere tiders ordninger for forsorg og forsørgelse, og det har - hvilket også er tilsiktet - $\mathrm{i}$ atskillig utstrekning kommet i stedet for tidligere pensjons- og forsikringsordninger. Gjennom den ordning som her er bygd opp, og de forventninger som derved er skapt, er det etablert posisjoner det ikke kan stå lovgiver fritt å rokke. $)^{49}$

I ettertid er det flere ganger slått fast at offentlige pensjons- og trygdeytelser er beskyttet under Grl. §97. ${ }^{50}$ Selv om praksis indikerer at graden av beskyttelse kan variere mellom ulike pensjonsrettigheter, ${ }^{51}$ synes den overordnete trenden å være at stiftelsesgrunnlaget - om pensjonsrettigheten har avtaleelementer eller er basert på innskudd - alt i alt har mindre betydning og at det avgjørende er en mer individuell vurdering av hvor sterke og velbegrunnede forventninger rettighetene gir grunnlag for. ${ }^{52}$ Fra en nokså formell

\footnotetext{
${ }^{44}$ Bjarte Thorson, Erstatningsrettslig vern for rene formuestap, Oslo 2011, s. 91 flg.

${ }^{45}$ At det gjelder en slik terskel for hva som utgjør beskyttede rettigheter etter Grl. § 97 forutsettes også av Castberg (1964) s. 198.

${ }^{46}$ Rt-1962-332 på s. 334. Også i senere rettspraksis er det forutsatt at statspensjoner kan stå i en særstilling og ha krav på et sterkere vern, se Rt-1996-1440 s. 1448-1449 og Rt-2006-262 avsnitt 75. Se også HR-2016-389-A hvor dette ble holdt åpent.

${ }^{47}$ Rt-1962-332 på s. 334.

48 Rt-1996-1415 på s. 1434.

${ }^{49}$ Rt-1996-1415 på s. 125.

50 Jf. Rt-1996-1440, Rt-2006-262, og HR-2016-389-A.

${ }^{51}$ Se særlig Rt-2006-262 avsnitt 75-78, og se også HR-2016-389-A avsnitt 86.

52 Se særlig HR-2016-389-A.
} 
tilnærming, der grunnlovsvernet primært ble ansett å avhenge av om det forelå et særskilt stiftelsesgrunnlag, er det i dag de sosiale hensyn knyttet til å utgjøre en sikkerhet for fremtidig livsoppholdelse og inntekt, som primært synes å begrunne grunnlovsvernet for offentlige pensjons- og trygdeytelser. ${ }^{53}$

I Rt-2013-1345 konkluderte både flertallet og mindretallet med at strukturkvoten utgjorde en rettighet som etter sin art var beskyttet av Grl. § 97. ${ }^{54}$ Rettigheten var heller ikke her basert på noe individuelt tilsagn fra staten til den enkelte fiskebåtreder, men ordningen var lagt opp slik at den enkelte reder som hadde flere fartøyer med kvoter kunne slå disse sammen på ett fartøy, ved at andre fartøyer ble tatt ut av drift og sanert. Ordningen var altså at rederen gjennom egne disposisjoner kunne utløse et ubetinget krav på en sammenslått "strukturkvote». Det var ingen uenighet mellom flertall og mindretall om at det dermed var etablert en beskyttet rett. Også flertallet fant at dette medførte en grunnlovsvernet rett:

«For at både staten og næringen skal oppnå sine mål, er det en forutsetning at den private parten sørger for at fart $\varnothing y$ tas ut av fisket. Tildelingen av strukturkvotene må her, sammen med kondemneringen og avkallet på fiskekvoter, anses som koordinerte ledd i samme tiltak. For at ordningen skal kunne fungere, må rederiene kunne innrette seg på at strukturkvoter vil bli gitt. En totalvurdering tilsier da at rederiene har etablert en rettsposisjon som kan være vernet av Grunnloven § 97. ${ }^{55}$

Rettspraksis forutsetter altså at det gjelder et kvalifikasjonskrav for at rettsposisjoner skal være vernet av Grl. § 97. Samtidig er et bredt spekter av rettigheter langt utover det vi normalt vil anse omfattet av et eiendomsbegrep omfattet av dette vernet. Ikke bare privatrettslige, men også offentligrettslige rettigheter, kan ha krav på vern.

Utgangspunktet må være at det primært er individuelle rettigheter som er beskyttet, altså rettigheter med et individualisert stiftelsesgrunnlag. Typisk vil dette kunne være ulike privatrettslige grunnlag, men ikke bare - for eksempel kan også myndighetsvedtak gi grunnlag for individuelle rettigheter. En rettsposisjon som ikke har annet grunnlag enn at den følger av loven eller rettsordenen vil derimot normalt ikke ha vern. ${ }^{56}$ Heller ikke en etablert bruk eller virksomhet vil normalt ha vern, så lenge den ikke har noe annet grunnlag enn den alminnelige handlefrihet. ${ }^{57} \mathrm{H} \varnothing$ yesterett har for eksempel lagt til grunn at adgangen til å drive fiskeoppdrett $f \varnothing r$ dagens konsesjonssystem ble innført ikke var vernet av tilbakevirkningsforbudet. ${ }^{58}$ Men også rettsposisjoner basert på lov uten noe særskilt, individualisert stiftelsesgrunnlag, kan i spesielle tilfeller ha vern. ${ }^{59}$ Som det ble formulert i Borthen-dommen må det avgjørende være om de aktuelle rettsposisjoner har «et

\footnotetext{
${ }^{53}$ Se Rt-1996-1415 særlig s. 1427 flg., Rt-1996-1440 s. 1448 flg., Rt-2006-262 avsnitt 81, HR-2016-389-A avsnitt 105.

${ }^{54}$ Rt-2013-1345 avsnitt 73-78 (flertallet), og avsnitt 175-182 (mindretallet).

${ }^{55}$ Rt-2013-1345 avsnitt 78.

${ }^{56}$ Slik også Bugge (1999) s. $81 \mathrm{flg}$.

${ }^{57}$ Bugge (1999) s. 80-81.

${ }^{58}$ Rt-1992-1511, og jf. også Rt-1961-554 om forbud mot notfiske.

59 Det forelå for eksempel ikke noe individuelt tilsagn fra myndighetene hverken i Rt-2006-293, Rt-2010-143 eller Rt-2013-1345.
} 
fundament og en karakter utover det at de er forankret i konkrete lovregler som tilsier at de må stå i en annen og sterkere stilling når det gjelder grunnlovsvern. ${ }^{60}$ Særlig vil det måtte ha betydning om lovregelen er ment å danne et grunnlag for enkeltpersoners eller virksomheters innrettelse og planlegging for fremtiden. ${ }^{61}$

\subsection{Eiendomsvernet under EMK P1-1}

i. Hovedelementene i eiendomsvernet - de tre «reglene»

I motsetning til Grl. § 97 (men i likhet med Grl. § 105) tilsikter eiendomsvernet under EMK P1-1 å beskytte privat eiendom og beslektede rettigheter. Bestemmelsens overordnete prinsipp er at privat eiendomsrett skal respekteres. Dette innebærer et mer generelt inngrepsvern enn den rene beskyttelsen mot ekspropriasjon som vi finner i Grl. § 105, men resultatet blir ikke så forskjellig fra det rettighetsvernet som følger av Grl. §§97 og 105 sett i sammenheng.

Man sier gjerne at P1-1 består av tre regler. ${ }^{62}$ Bestemmelsens overordnete prinsipp er retten til å nyte sin eiendom i fred (prinsippregelen), ${ }^{63}$ som komplementeres av to mer spesifikke og motstående utgangspunkter; avståelsesregelen ${ }^{64}$ og kontrollregelen. ${ }^{65}$ Slik bestemmelsen er blitt tolket innebærer dette et overordnet krav om at inngrep i privat eiendom må være forholdsmessige (som gjerne formuleres som et krav til «fair balance»), ${ }^{66}$ og ikke utgjøre en «individual and excessive burden» for den enkelte som rammes. ${ }^{67}$

Både avståelsesregelen og kontrollregelen må anses som utslag av dette overordnete forholdsmessighetsprinsippet. ${ }^{68}$ Men de gir ulike utgangspunkter for vurderingen: Selv om det ikke følger av ordlyden er det således klart at avståelsesregelen («no one shall be deprived of») normalt forutsetter at det gis erstatning for tapet av den avståtte rettigheten,

\footnotetext{
${ }^{60}$ Rt-1996-1415 på s. 1426.

${ }^{61}$ Et eksempel på dette i en litt annen lei enn trygderettigheter er et antatt vern for individuelle forventninger og innrettelse under en stadfestet reguleringsplan. Selv om planen ikke kan gi grunnlag for berettigede forventninger om fremtiden, er det blitt antatt å gjelde en særlig regel, forankret i Grl. §§ 97 og 105, om at spilte utgifter pådratt i tillit til en stadfestet reguleringsplan som senere endres, kan kreves erstattet fra planmyndighetene på objektivt grunnlag. Forutsetningen er at byggherren ikke med rimelighet kunne ha forutsett reguleringsendringen, og at de spilte utgiftene ikke fremstår som uvesentlige. Jf. Rt-1994-813, s. 820821.

${ }^{62}$ Sporrong and Lönnroth v. Sweden, No. 7151/75; 7152/75 (1982), para. 61; og generelt Harris, O’Boyle and Warbrick, Law of the European Convention on Human Rights, 4. utg., Oxford 2018, s. 862.

63 Jf. første setning i bestemmelsen: "Every natural or legal person is entitled to the peaceful enjoyment of his possessions."

$64 \mathrm{Jf}$. andre setning i bestemmelsen: "No one shall be deprived of his possessions except in the public interest and subject to the conditions provided for by law and by the general principles of international law."

65 Jf. tredje setning i bestemmelsen: "The preceding provisions shall not, however, in any way impair the right of a State to enforce such laws as it deems necessary to control the use of property in accordance with the general interest or to secure the payment of taxes or other contributions or penalties."

${ }^{66}$ Sporrong and Lönnroth v. Sweden, No. 7151/75; 7152/75 (1982), avsnitt 69.

67 Ibid. avsnitt 73.

${ }^{68}$ James and others v. UK, No. 8793/79 (1986), avsnitt 37.
} 
som må være «reasonably related to its value». ${ }^{69}$ Under kontrollregelen er derimot utgangspunktet at noen slik erstatning ikke kan kreves med mindre reguleringen er «arbitrary or unreasonable», ${ }^{70}$ eller den enkelte som rammes av reguleringen påføres en «disproportionate and excessive burden». ${ }^{71}$

Sagt på en annen måte: prinsippet om at privat eiendom skal respekteres, og det grunnleggende kravet til forholdsmessighet som er blitt utledet fra dette, innebærer at den enkelte i utgangspunktet er beskyttet mot å måtte avstå sine rettigheter uten erstatning, men normalt ikke mot at bestående rettigheter reguleres. Et inngrep som ikke anses som enten regulering eller avståelse aktualiserer ikke noe tilsvarende klart utgangspunkt - her avhenger inngrepsvernet av den overordnete og åpnere forholdsmessighetsnormen som følger av hovedprinsippet. ${ }^{72}$

\section{ii. Konvensjonens eiendomsbegrep}

For at eiendomsvernet skal komme til anvendelse må det foreligge en rettighet som kvalifiserer som eiendom. ${ }^{73}$ Gjennom en omfattende rettspraksis har menneskerettighetsdomstolen utviklet en vid fortolkning, herunder til å omfatte andre aktiva og krav som det kan knyttes berettigede forventninger til. ${ }^{74}$ Domstolen har fremholdt at konvensjonens eiendomsbegrep er autonomt, men rettigheten må ha et grunnlag i nasjonal rett. ${ }^{75}$ I tvilstilfeller vil spørsmålet om det foreligger eiendom bero på en helhetsvurdering. ${ }^{76}$ Et grunnleggende skille går videre mellom «existing possessions» og «assets, including claims, in respect of which the applicant can argue that he has at least a 'legitimate expectation' of obtaining effective enjoyment of a property right. $)^{77}$

\footnotetext{
${ }^{69}$ Dette innebærer igjen normalt et krav til full erstatning, med mindre sterke grunner taler for noe annet. Jf. Holy Monasteries v. Greece, No. 13092/87; 13984/88 (1994), avsnitt 71; og se også generelt Harris, O'Boyle and Warbrick (2018) s. 878; og Jacobs, White and Ovey, The European Convention on Human Rights, 6. utg (ved Bernadette Rainey, Elizabeth Wicks og Clare Ovey), Oxford 2014, s. 507.

${ }^{70}$ Harris, O’Boyle and Warbrick (2018) s. 886.

${ }^{71}$ Hutten-Czapska v. Poland, No. 35014/97 (2006), avsnitt 167.

72 Stig Solheim, Eiendomsbegrepet i Den Europeiske menneskerettskonvensjon, Oslo 2010, s. 71-74

${ }^{73}$ Det vi kan kalle inngangskriteriene for anvendelsen av P1-1 er at det må foreligge en «possession» (eiendomskriteriet) og et inngrep i denne (inngrepskriteriet) - deretter vil EMD gjerne vurdere hva slags inngrep som foreligger, om inngrepet har hjemmel og forfølger et legitimt formål, og om det er proporsjonalt. At en rettighet utgjør eiendom medfører at inngrep i retten må ha hjemmel i nasjonal rett, forfølge et offentlig formål og være forholdsmessige. Se generelt om forholdet mellom eiendomskriteriet og de $\varnothing$ vrige vurderingstemaene utviklet av EMD under P1-1, Solheim (2010) s. $58 \mathrm{flg}$.

${ }^{74}$ Se generelt Solheim (2010), og Maya Sigron, Legitimate expectations under Article 1 of Protocol No. 1 to the European Convention on Human Rights, Cambridge 2014. Jf. også Rt-2006-1382 (avsnitt 54): «Omgrepet eigedom er autonomt i EMK, og det omfattar meir enn det vi oppfattar som eigedom etter vanleg norsk rett.» ${ }^{75}$ Solheim (2010) s. 149 og 169 flg.

${ }^{76}$ Anheuser-Busch inc. v. Portugal, No. 73049/01 (2007), avsnitt 63.

77 Jan Malhous v. the Czech Republic, No. 33071/96 (2000); og se også Kopecky v. Slovakia No. 44912/98 (2004). Se generelt Solheim (2010) s. 146 flg.; og Sigron (2014) s. 73-74.
} 
Rettigheter som av domstolen anses som eksisterende eiendom er litt løselig det vi i norsk rett vil karakterisere som "tinglige» rettigheter, ${ }^{78}$ slik som grunneiendomsrett og eiendomsrett til løsøre, men også panterett, immaterielle rettigheter som patenter og opphavsrettigheter, aksjer og i noen sammenhenger penger (for eksempel en bankkonto). ${ }^{79}$ Domstolen skiller særlig mellom slike rettigheter, og berettigede forventninger i form av krav om å oppnå en bestemt, fremtidig eiendomsposisjon. ${ }^{80}$ Noen helt klar skillelinje er det likevel ikke nødvendig å trekke, siden det i tvilstilfeller typisk er avgjørende om rettighetshaveren har en berettiget forventning.

For at en berettiget forventning skal være beskyttet må den knyttes til et aktivum eller en eiendomsinteresse. Slik domstolen har fortolket dette synes det likevel ikke å innebære noen særlig omfattende begrensning. Man kan ha eiendomsrett til penger, noe som betyr at en berettiget forventning som kan formuleres i form av et pengekrav vil være beskyttet. ${ }^{81}$ Det sentrale synes å være at den berettigede forventning enten må knytte seg til utnyttelsen av en eksisterende eiendomsrett, ${ }^{82}$ eller ta form av et krav om å oppnå en eiendomsposisjon som i seg selv fremstår så klart, aktuelt og endelig at det kan anses som eiendom. ${ }^{83}$ Det er imidlertid ikke noe vilkår at kravet har et privatrettslig stiftelsesgrunnlag. I en rekke avgjørelser har domstolen lagt til grunn at typiske offentligrettslige rettigheter som offentlige tillatelser og konsesjoner, trygd- og velferdsytelser i vid utstrekning er omfattet av konvensjonens eiendomsbegrep. ${ }^{84}$

De betraktninger menneskerettighetsdomstolen bygger på ved sin tolkning av eiendomsbegrepet under EMK P1-1 synes i lys av dette langt på vei å være sammenfallende med vurderingen av om en rettighet er beskyttet under Grl. § 97 . Noe nødvendig sammenfall i tolkning medfører dette naturligvis ikke, og Høyesterett har i liten grad uttrykkelig vist til EMDs praksis ved tolkningen av Grl. § 97. Sammenfallet i vurderingstema tilsier likevel at

\footnotetext{
${ }^{78}$ Hvor viktig skillet mellom tinglige og obligatoriske rettigheter er som rettslig kriterium er mer diskutabelt, se nærmere Solheim (2010) s. 195. Også under norsk rett er skillet problematisk. Tinglige rettigheter defineres gjerne som en rett (eller rådighet) over et objekt som gir krav på beskyttelse mot alle eller en ubestemt krets, $\mathrm{i}$ motsetning til «obligatoriske» rettigheter som kun kan gjøres gjeldende overfor skyldneren. At man anser tinglige rettigheter som noe vesensforskjellig fra obligatoriske rettigheter innebærer typisk det vi vil kalle et substansielt eiendomsrettsbegrep, i den forstand at vi anser eiendomsretten som en primær relasjon mellom eieren og tingen som ikke kan reduseres til et gitt antall beføyelser eller obligatoriske/bilaterale rettsforhold. Skillet mellom tinglige og obligatoriske rettigheter var gjenstand for omfattende kritikk fra den skandinaviske «rettsrealistiske» tradisjonen, med Alf Ross som en fremtredende representant, og fortsatt i dag er det betydelig skepsis i tingsrettslitteraturen mot et substansielt eiendomsrettsbegrep. Se om dette og for kritikk, Erlend Baldersheim, Til tingsrettens teori, Oslo 2017; og Harris (2001), særlig s. 130 flg.

${ }^{79}$ Solheim (2010) s. 182-217.

80 Se storkammeravgjørelsen i Kopecký v. Slovakia, No. 44912/98 (2004), avsnitt 41: "It was not suggested that title to the property he sought to recover vested in him without the intervention of the courts. The proprietary interest relied on by the applicant was therefore in the nature of a claim and cannot accordingly be characterised as an "existing possession" within the meaning of the Court's case-law."

${ }^{81}$ Se for eksempel Case of Pressos Compania Naviera s.a. and others v. Belgium, No. 17849/91 (1995).

82 Nedenfor pkt. 4.1.

${ }^{83}$ Kopecký v. Slovakia, No. 44912/98 (2004), avsnitt 45 flg.

${ }^{84}$ Se generelt Jacobs, White and Ovey (2014) s. 498-499.
} 
rekkevidden av Grl. § 97 ikke kan eller bør fastlegges helt uavhengig av hvordan menneskerettighetsdomstolen har fortolket P1-1.

\subsection{Grunnlovens ekspropriasjonsvern - § 105}

i. Beskyttelsen mot å måtte avgi eiendom

I vår norske grunnlov har den såkalte avståelsesregelen under EMK P1-1 sin parallell i ekspropriasjonsvernet under $\S 105$, som slår fast at ingen skal måtte avgi sin eiendom til det offentlige uten full erstatning. Ekspropriasjonsvernet bygger på en lang idétradisjon rundt forholdet mellom den private eiendomsrett og statsmakten. ${ }^{85}$ Rundt 1814 stod liberale ideer om vern av eiendomsretten sterkt. ${ }^{86}$ Det absolutte vernet av privat eiendom mot statlig tilegnelse og omfordeling er likevel ikke like ukontroversielt som den grunnleggende rettsstatsgarantien som ligger i forbudet mot tilbakevirkning, og det finnes også en rekke ulike og motstridende teorier om hvorfor (eventuelt hvorfor ikke) individuell eiendomsrett fortjener vern. ${ }^{87} \mathrm{Når}$ vi uomtvistet har et konstitusjonelt eiendomsvern både i Norge, og de fleste andre land, kan vi likevel se det slik at dette bygger på visse bestemte hensyn knyttet til opprettholdelsen av privat eiendomsrett, slik som et hensyn til individuell frihet og autonomi, og å legge til rette for individuelt arbeid, initiativ og skaperkraft. Beskyttelsen av eiendomsretten mot statsmakten er et sentralt element i den moderne, liberale rettstatsordning, som de siste hundreår har skapt en enestående økonomisk vekst og velstand, blant annet gjennom å tilrettelegge for det man kan kalle sammenfallet av individuelle, private interesser med fellesnytten ved å beskytte privat eiendomsrett. ${ }^{88}$

Ekspropriasjonsvernet under Grl. § 105 avhenger ikke av om inngrepet fremstår uforholdsmessig eller urimelig overfor den enkelte. Også den som i og for seg godt kan tåle å måtte dele av sin rikdom er beskyttet. Når § 105 kun gir krav om erstatning der noen må «avgi» sin eiendom, har dette sammenheng med at bestemmelsen primært skal beskytte mot at staten eller fellesskapet tilegner seg noens eiendom og formue. Det er altså ikke tapet av rådighet eller forventninger om fremtidig utnyttelse i seg selv bestemmelsen beskytter mot, men at man tvinges til å avgi sin eiendom til fordel for det offentlige. Det sentrale elementet i ekspropriasjonsbegrepet er slik sett at det skjer en form for formuesoverføring til det offentlige ${ }^{89}$ At staten kan regulere utnyttelsen av privat eiendomsrett er egentlig en selvfølgelighet. ${ }^{90}$ Man kan selvfølgelig ikke $m \varnothing$ te et forelegg for fartsovertredelse med den innvending at dette krenker ens eiendomsrett til bilen man kjørte

\footnotetext{
${ }^{85}$ Se for eksempel Richard Schlatter, Property - the History of an Idea, London 1951.

${ }^{86}$ Ivar Alvik, «Grl. § 105» i Ola Mestad og Dag Michalsen, Grunnloven: Historisk kommentarutgave, Oslo 2021 (under publisering).

87 Se generelt Schlatter (1951) og for diskusjon Harris (2001), særlig s. $165 \mathrm{flg}$

${ }^{88}$ Dette er den sentrale betraktning hos Douglas C. North og Robert Paul Thomas, The Rise of the Western World: A New Economic History, Cambridge 1973, s. 2-3.

${ }^{89}$ Dette forhindrer likevel ikke at ekspropriasjonsvernet også beskytter mot at man tvinges til å avgi eiendom til andre private parter gjennom et offentlig pålegg. Men i praksis vil et slikt pålegg alltid kreve at avgivelsen kan forankres i noe som anses som en offentlig interesse, jf. oreigningslova § 2, noe som også er et vilkår under EMK P1-1.

${ }^{90}$ Fleischer (1968) s. 204 flg.
} 
for fort med. Det som ofte vil være spørsmålet er imidlertid om en aktuell eiendomsrett har et etablert innhold eller gir grunnlag for berettigede forventninger, som gjør at en rådighetsinnskrenkning langt på vei må likestilles med at man avgir en bestemt del av eiendomsretten eller en særrett. ${ }^{91}$

Med hensyn på dette har det lenge vært antatt i norsk rett at selv svært omfattende rådighetsinngrep ikke gir krav om erstatning. ${ }^{92}$ Samtidig antas det å gjelde et unntak hvis «inngrepet er av en slik karakter at det ut fra en helhetsvurdering vil være sterkt urimelig om inngrepet skal tåles. ${ }^{93}$ Dette synes umiddelbart nokså sammenfallende med «klart urimelig eller urettferdig»-normen som er trukket opp av Høyesterett under Grl. § 97, noe som ikke er tilfeldig. Et rådighetsinngrep i eiendomsrett etter $\S 105$ kan jo nettopp ses som tilbakevirkning overfor en etablert rettsposisjon etter § 97. Det taler for at normen også må være den samme: et utgangspunkt om at regulering av fremtidig utnyttelse må tåles inntil det klart urimelige eller uforholdsmessige. Et synspunkt i forlengelsen av dette kunne være at beskyttelsen mot rådighetsinnskrenkninger egentlig ikke følger av Grl. § 105, verken direkte eller analogisk, og at «sterkt urimelig»-unntaket som $\mathrm{H} \varnothing$ yesterett har anvendt ved rådighetsinnskrenkninger under Grl. § 105 i realiteten er avveiningsnormen under § $97 \mathrm{i}$ forkledning.

Å insistere på at Grl. § 105 ikke beskytter mot noen form for rådighetsinnskrenkning blir likevel for unyansert. Bestemmelsen beskytter mot delvis avgivelse, altså at noen må avgi en definert del av sin eiendom til det offentlige. Den som må avstå deler av sin grunn til for eksempel veibygging skal selvfølgelig ha erstatning. Dette må også gjelde der noen må avstå en definert del av selve eiendomsretten, ${ }^{94}$ for eksempel der staten betinger seg eller noen andre en bestemt bruksrett over en gitt ting eller grunneiendom. ${ }^{95}$ Her kan grensen mot hva som bare utgjør en ikke-erstatningsbetingende rådighetsinnskrenkning bli uklar. I

bankdemokratiseringssaken kom for eksempel Høyesterett i plenum til at ny lovgivning, som fratok aksjonærene den øverste myndighet i forretningsbankene og i stedet la denne til et politisk oppnevnt representantskap, utgjorde ekspropriasjon som utløste kravet om full erstatning. ${ }^{96}$

Poenget her, som vi skal komme nærmere tilbake til, er at inngrep i klart definerte og positivt angitte rettigheter lettere får et avståelsespreg. Samtidig er det her også en forbindelse mellom tilbakevirkning og avståelse. Langt på vei er det de samme inngrepene

\footnotetext{
91 Jf. nærmere nedenfor pkt. 4.3.

92 Det klassiske prejudikatet er strandlovdommen i Rt-1970-67, jf. nedenfor pkt. 3.2.

93 Rt-2004-1092 og Rt-2005-469. Sitatet er hentet fra høyesterettsdommer Skoghøys artikkel «Rådighetsinnskrenkninger og erstatning» i Lov og Rett (1995) s. 213, som Høyesterett siterer og slutter seg til i den første saken. Se også nærmere nedenfor pkt. 4.3.

${ }^{94}$ Grensene for hva som utgjør ekspropriasjon er likevel ofte blitt trukket forholdsvis snevert, jf. Rt-2005-607:

Et konsesjonsvilkår som påla overdragelse av en del av eiendommen til det offentlige ble ikke ansett som ekspropriasjon.

${ }^{95}$ Rt-2004-1985 avsnitt 43. Høyesterett kom likevel til at det ikke forelå noen avståelse som ga rett på erstatning, blant annet fordi inngrepet (at barn under 16 år fikk rett til å fiske) ikke var særlig vesentlig, jf. også nedenfor pkt. 4.4.

${ }^{96}$ Rt-1979-572, se nærmere nedenfor pkt. 4.3.
} 
som har et sterkt tilbakevirkningselement fordi de griper inn i konkret forutsatte virkninger av fortidige disposisjoner og handlinger, som også vil kunne utgjøre ekspropriasjonsartet avståelse eller delavståelse av en opparbeidet rettighet og gi krav om erstatning under Grl. § 105. I dette ligger egentlig et mer grunnleggende spørsmål, som vi skal komme tilbake til nedenfor, nemlig om og når regulering som griper inn i særretter eller berettigede forventninger kan aktualisere et skjerpet forholdsmessighetskrav. Som vi skal se har dette spørsmålet en side til både Grl. §§ 97 og 105, og avståelsesregelen under EMK P1-1.

ii. Hva som utgjør «eiendom» under Grl. § 105

I likhet med P1-1 beskytter Grl. § 105 «eiendom». Slik Høyesterett har tolket bestemmelsen omfatter dette også andre rettigheter enn det vi tradisjonelt vil omtale som eiendom. I eldre rettspraksis finner man eksempler på at både konsesjoner, kontrakter og statlige embetsprivilegier har blitt ansett som eiendom i relasjon til Grl. $§ 105 .{ }^{97}$ I det hele tatt synes en etablert oppfatning i eldre rettspraksis og litteratur å ha vært at rettighetsvernet under Grl. §§97 og 105 er sammenfallende, i den forstand at det er de samme egenskaper som gjør at en rettighet utgjør eiendom under Grl. § 105 som også aktualiserer tilbakevirkningsforbudet under Grl. § 97. ${ }^{98}$ Spørsmålet er imidlertid om en slik forutsetning kan opprettholdes i dag.

At ekspropriasjonsvernet er absolutt kan tilsi en høyere terskel for hvilke rettigheter som er beskyttet. Hvor beskyttelsesverdig den aktuelle rettighet er, vil under Grl. § 105 utelukkende være relevant for spørsmålet om ekspropriasjonsvernet kommer til anvendelse. Under Grl. § 97 (og EMK P1-1) er dette derimot både et moment i vurderingen av anvendelighet og forholdsmessighet. Når mye av substansvurderingen slik foretas gjennom avveiningsnormen kan det tilsi et åpnere rettighetsbegrep. Dette vil jo kun ha som funksjon å avgrense når avveiningsnormen er anvendelig.

Dommene om beskyttelse av pensjonsrettigheter under Grl. § 97 illustrerer poenget. I Borthen-dommen kom flertallet til at det forelå et grunnlovbeskyttet krav på pensjonsytelser, men den fremtidige reduksjonen i ytelsene var ikke «klart urimelig eller urettferdig». Dermed var inngrepet i samsvar med grunnloven. ${ }^{99}$ Dersom vi hadde sett pensjonsytelsen som en form for eiendomsrett som var beskyttet under Grl. § 105, er det vanskelig å forklare hvorfor reduksjonen i den allerede eksisterende og fastlagte, klart definerte ytelsen på pensjon, ikke utgjorde en delvis avståelse. ${ }^{100}$ Hvis staten hadde vært

\footnotetext{
${ }^{97}$ Se om Høyesteretts praksis fra tiden rett etter 1814 knyttet til særlig embetsprivilegier, Nils Rune Langeland, Siste ord - Høyesterett i norsk historie 1814 - 1965, Bind 1, Oslo 2005, s. 318 flg. For senere praksis, se Rt-1890435, Rt-1895-297, Rt-1909-417, Rt-1917-392, Rt-1917-402, Rt-1923-208, Rt-1929-1011, Rt-1949-772, Rt-1955571, Rt-1956-1149, Rt-1969-787, og jf også Rt-2014-560, avsnitt 51.

98 Se særlig Rt-1890-435, Rt-1895-297 og Rt-1909-417, og generelt Knoph (1948) s. 103 flg.

99 Rt-1996-1415.

${ }^{100}$ Et mulig synspunkt kunne likevel være at det ikke er den bestemte og fastlagte pensjonsytelsen som følger av lovgivningen til enhver tid som er beskyttet som «eiendom» men en mer udefinert rett til en rimelig, fremtidig pensjon. Dommen i HR-2016-389-A kan gi holdepunkter i den retning, jf. særlig avsnitt 115. Samtidig ble det fremholdt i dommen at saken gjaldt statspensjon med tilknytning til «arbeidsforholdet» som stortingsrepresentant, som dermed hadde en særstilling: "Jeg ser det slik at disse pensjonene dermed nyter et sterkere vern mot inngrep enn det som gjelder for trygderettigheter og sosiale ytelser for $\emptyset$ vrig».
} 
avtaleforpliktet med hensyn til de aktuelle pensjonsytelsene kunne det ha vært mer nærliggende å se det slik at det også forelå beskyttet eiendom etter Grl. § 105, og at reduksjonen $\mathrm{i}$ ytelsen dermed også hadde vært grunnlovsstridig. ${ }^{101}$ I så fall ville spørsmålet kanskje måtte vært om reduksjonen i ytelsen var vesentlig, og ikke om inngrepet var «klart urimelig eller urettferdig». ${ }^{102}$

Også uenigheten mellom fraksjonene i strukturkvotedommen kan ses i lys av slike betraktninger. ${ }^{103}$ Dersom man legger til grunn at strukturkvoten utgjorde «eiendom " etter Grl. § 105, synes mindretallets synspunkt om at inngrepet hadde et avståelseselement nærliggende. Når den aktuelle rettigheten gikk fra å være tidsubegrenset til å ha en utløpsdato kunne man se det slik at det forelå krav om både en fremtidig og delvis avståelse - en tidsmessig definert del av rettigheten måtte avstås. ${ }^{104}$ Flertallets synspunkt om at inngrepet var rettmessig fordi det ikke var "klart urimelig eller urettferdig» forutsetter egentlig at det ikke gjennom strukturkvoten var etablert noen distinkt rett med eiendomskarakter i Grl. § 105s forstand. ${ }^{105}$

Rettspraksis gir følgelig visse holdepunkter for at det ikke nødvendigvis er de samme rettigheter som er beskyttet under Grl. $\S \S 97$ og $105 .{ }^{106}$ Henvisninger til eiendomsbegrepet i $\S 105$ forutsetter gjerne at dette vil innebære sterkere beskyttelse. ${ }^{107}$ Det underliggende synspunktet må være at Grl. § 105 forutsetter et strengere eiendomsbegrep enn det som er tilfellet under både Grl. § 97 og P1-1, nettopp fordi vernet er absolutt. ${ }^{108}$

\subsection{Oppsummering og ansats}

Over har vi sett at vernet av $\varnothing$ konomiske rettigheter, slik dette er forankret i henholdsvis Grl. $\S \S 97$ og 105 og EMK P1-1, bygger på enkelte felles grunnelementer: et bestemt rettighetsbegrep, et skille mellom regulering og avståelse og et krav til at inngrep må være forholdsmessige.

Under både Grl. § 97 og EMK P1-1 består rettighetsvernet i en fleksibel avveiningsnorm og et nokså åpent rettighetsbegrep. Under EMK P1-1 er også inngrep som har karakter av

\footnotetext{
101 Jf. Rt-1962-332 og særlig Rt-1996-1440. I sistnevnte dom ble det anført at tilleggspensjonen hadde avtaleelementer som ga beskyttelse som en særrett under $§ 105$ på linje med statspensjoner. Høyesterett avviste imidlertid at tilleggspensjonene hadde noen slike elementer av selvstendig tilsagn eller avtale, se særlig s. $1448 \mathrm{flg}$. Se også dommer Backers dissenterende votum, som la til grunn at det var etablert en særrett under Grl. § 97 men samtidig avviste at Grl. § 105 hadde noen selvstendig betydning ved siden av Grl. § 97.

102 Jf. nærmere nedenfor pkt. 4.4.

${ }^{103}$ Rt-2013-1345.

104 Se særlig tredjevoterende dommer Skoghøy, avsnitt 240-241.

105 Rt-2013-1345 avsnitt 78.

${ }^{106}$ I rettspraksis reflekteres dette også gjennom at forholdet til Grl. § 105 ved inngrep i rettigheter som ikke utgjør eiendom i tradisjonell forstand enten ikke problematiseres, jf Rt-2006-262, Rt-2006-293, Rt-2010-143 (rederiskatt), Rt-2013-1345 (strukturkvote) og HR-2016-389-A, eller til og med uttrykkelig anses å aktualisere Grl. § 97 til fortrengsel for § 105, jf. Rt-2007-1281.

107 Rt-1996-1440.

108 Tilsvarende kan nok dette tilsi at også grensen for hva som utgjør avståelse eller ekspropriasjon trekkes snevrere enn under EMK P1-1, jf. Rt-2005-607. Høyesterett kom imidlertid til at heller ikke avståelsesregelen under P1-1 kunne gi krav om høyere erstatning, jf. avsnitt 63. .
} 
avståelse omfattet av avveiningsnormen, men det gjelder et utgangspunkt om erstatning og dermed et skjerpet krav til forholdsmessighet der erstatning ikke gis. Avståelsesvernet under Grl. § 105 er derimot absolutt, men har dermed også et noe snevrere anvendelsesområde.

Spørsmålet som skal drøftes i de resterende delene av denne artikkelen er om det gjelder et skjerpet forholdsmessighetskrav ved regulatoriske inngrep som rokker ved visse faste og etablerte rettigheter, eller berettigede forventninger. Prinsipielt kan man se det slik at utgangspunktet om at regulering må tåles her støter sammen med utgangspunktet om avståelsesvern. Som vi skal komme tilbake til følger disse utgangspunktene nokså klart av hvordan menneskerettsdomstolen har fortolket EMK P1-1. ${ }^{109}$ Men vi skal se at det også er holdepunkter for lignende synspunkter under Grl. §§ 97 og 105. I denne sammenhengen kan det være grunn til å trekke frem to viktige egenskaper ved økonomiske rettigheter:

For det første, rettigheter er rettsvirkninger av tidligere handlinger og disposisjoner, men den enkelte rettighet kan ha en større eller mindre grad av bestemthet og positivering. Hvor direkte og umiddelbart en bestemt rettsvirkning fremstår som en forutsigbar konsekvens av en tidligere disposisjon eller handling vil dermed variere. En eiendomsrett er $\mathrm{i}$ utgangspunktet en ubestemt, negativ rettighet som gir rett til å utnytte et objekt på alle måter som rettsordenen ikke forbyr. Andre typer rettigheter kan derimot gi en positiv rett til noe bestemt, for eksempel å være fritatt for en plikt, å motta en ytelse, eller å utføre en gitt aktivitet. En viktig gruppe av slike rettigheter er offentlige avtaleforpliktelser, tilsagn, tillatelser og konsesjoner. ${ }^{110}$ Det er naturligvis en vesentlig forskjell på å regulere en negativ, ubestemt rettighet, og en positivt angitt rett til noe bestemt. Der en positivt angitt rettighet innskrenkes kan det noen ganger ses som delvis avståelse av en opparbeidet rettighet. ${ }^{111}$ Dette vil ofte ikke i samme grad være tilfelle der friheten til å utnytte en eiendomsrett på ulike måter innskrenkes.

For det andre, økonomiske rettigheter eksisterer normalt ikke isolert. En bestemt rettsposisjon består gjerne av et knippe mer eller mindre sammenbundne rettigheter (og noen ganger plikter). En eiendomsrett til grunn, løs øre eller bestemte bygg eller innretninger kan være forbundet med konsesjoner og offentlige tillatelser til å drive en virksomhet eller utføre en aktivitet. En kontrakt kan ofte ses som et sammensatt rettsforhold som består av flere mer eller mindre sammenbundne rettigheter, plikter og krav. Også tradisjonell eiendomsrett til grunn eller ting kan man se som bestående av flere ulike relasjoner og krav. En regulering av bestemte eiendommer eller virksomhet vil dermed også kunne innebære at særlige rettigheter eller krav, som inngår i eller utledes fra den mer omfattende rettigheten til eiendommen eller virksomheten, helt eller delvis må avstås. Eksempler kan være der en

\footnotetext{
${ }^{109}$ Nedenfor pkt. 3.3

${ }^{110}$ Se nærmere Ivar Alvik og Henrik Bjørnebye, «Om konsesjoner og konsesjonsrett» Jussens venner, Årg. 55 (2) 2020, s. 85-104.

${ }^{111}$ Se for eksempel departementets drøftelser av adgangen til revisjon av vassdragskonsesjoner i forarbeidene til vassdragsreguleringsloven $\S 8$, hvor det skilles mellom revisjon/regulering, og inngrep i «konsesjonen som sådan, det essensielle ved tillatelsen som f.eks. bestemmelser om reguleringshøyder, selve overføringen osv.» Ot.prp.nr.50 (1991-1992) Om lov om endringer i vassdragsreguleringsloven m.fl., s. 40 flg., på s. 47.
} 
bestemt kontraktsrettighet annulleres eller en konsesjonert virksomhet innskrenkes eller forbys. ${ }^{112}$

Utfordringen som følger med et slikt mer nyansert rettighetsbegrep, er nettopp at det ikke alltid er like opplagt om det er avståelses- eller reguleringsperspektivet som bør anses mest fremtredende. Som vi skal se kan et mer eller mindre uttalt begrep om berettigede forventninger her ha en sentral rolle.

\section{Nærmere om avveiningsnormen}

\subsection{Innledning}

Som redegjort for over bygger både grunnlovs- og menneskerettighetsvernet på en distinksjon mellom avståelse og regulering. I det følgende ser jeg nærmere på de grunnleggende elementene i avveiningsnormen som kommer til anvendelse ved regulatoriske inngrep. Før vi går nærmere inn på elementene i normen bør det presiseres at Grunnlovens utgangspunkt er at alle regulatoriske inngrep aktualiserer avveiningsnormen. Dette står i motsetning til den absolutte erstatningsplikten som følger av Grl. § 105 der noen må «avgi» sin eiendom «til offentlig bruk». Det er også verdt å minne om at skillelinjen mellom regulering og ekspropriasjon ikke knyttes til et begrep om avståelse. Den grunnleggende skillelinjen går mellom det negative, at en rettighet eller rettsposisjon innskrenkes for fremtiden, og det positive, at det skjer en overføring av rådighet til det offentlige (eller av hensyn til en offentlig interesse). ${ }^{113}$ Selv der en bestående rettighet mister all verdi som følge av et offentlig forbud eller påbud om fremtidig bruk og utnyttelse, og inngrepet dermed har et klart avståelseselement, er utgangspunktet etter Grunnloven følgelig at det er tale om regulering («rådighetsinnskrenkning»). Vi må holde fast ved at slike rent negative inngrep i prinsippet aktualiserer avveiningsnormen, og ikke den absolutte erstatningsplikten som følger av Grl. § 105. Samtidig er spørsmålet om avveiningsnormen alltid er den samme, uavhengig av hvor omfattende det aktuelle inngrepet er.

Vi skal begynne med å se på det grunnleggende utgangspunktet - nemlig at regulering må tåles (pkt. 3.2). Vi skal så se nærmere på det primære unntaket som er utkrystallisert i både Høyesteretts praksis under Grl. §§ 97 og 105, og menneskerettighetsdomstolens tolkning av EMK P1-1, for klart uforholdsmessige inngrep (pkt. 3.3). Deretter drøfter jeg om dette kriteriet er dekkende for alle rettighetsinngrep av regulatorisk art. Dette aktualiserer særlig et spørsmål om «sterke samfunnsmessige hensyn»-normen, som Høyesterett har bygget på i noen saker, gjelder ved inngrep i rettigheter (punkt 3.4).

\subsection{Utgangspunktet om at regulering må tåles}

Når en bestemt rettsposisjon innholdsmessig begrenses eller innskrenkes gjennom etterfølgende lovgivning, er det noe litt annet enn at den alminnelige handlefrihet defineres

\footnotetext{
112 Se for eksempel Rt-1962-369, Rt-1990-284 og HR-2018-1258-A avsnitt 120-123.

${ }^{113}$ At overføringen er begrunnet i en offentlig interesse vil normalt være et vilkår for at ekspropriasjon skal være lovlig, jf note 89 over. Det forhindrer ikke at et krav om overføring til private kan utgjøre ekspropriasjon som forutsetter full erstatning.
} 
gjennom lovgivningen til enhver tid. ${ }^{114}$ Særlig der det foreligger mer eller mindre festnede og avklarte rettsposisjoner er det mulig å skille mellom lovgivning som på den ene siden griper inn i og innskrenker selve rettigheten, og som på den annen side kun regulerer utnyttelsen av den for fremtiden. Det er ikke prima facie opplagt at lovgivningen skal stå like fritt til å gripe inn i og innskrenke etablerte rettigheter med et fast og avklart innhold, som til å regulere fremtidig utnyttelse av andre og mer ubestemte rettigheter. ${ }^{115}$

Synet på hvor langt økonomiske rettigheter er beskyttet mot etterfølgende lovgivning har variert. Mens juridisk teori i første halvdel av 1800-tallet gjerne fremholdt at Grunnloven ikke la særlig bånd på lovgivningen, ${ }^{116}$ kom deretter den mer ekspansive rettsregel- eller rettighetsteorien til å råde grunnen frem til begynnelsen av det 20 . århundre. ${ }^{117}$ Visse, etablerte rettigheter ble ansett som uangripelige, og dermed immune overfor etterfølgende lovgivning. Dette bet $\varnothing \mathrm{d}$ selvfølgelig ikke at man mente at utnyttelsen av eiendom og rettigheter ikke kunne reguleres. ${ }^{118}$ Men man så det slik at enkelte rettigheter kunne ha et så festnet og avklart innhold at de hadde krav på beskyttelse. Aschehoug hevdet for eksempel at hvor langt en rettighet var beskyttet mot etterfølgende lovgivning primært kom an på dens egen beskaffenhet, og om rettigheten var tillagt «individet væsentlig for dets egen skyld. $)^{119}$ | så fall var utgangspunktet at rettigheten var ervervet, i den forstand at den var uangripelig eller ukrenkelig. Den kunne ikke gjennom senere lovgivning hverken oppheves eller innskrenkes. ${ }^{120}$ I en rekke avgjørelser opp gjennom 1800-tallet fant Høyesterett, tilsynelatende i samsvar med et slikt alminnelig utgangspunkt, at ulike typer næringsrettigheter under ulike navn utgjorde beskyttede rettigheter, som ikke kunne fratas den enkelte gjennom senere lovgivning. ${ }^{121}$

Denne oppfatningen kunne ikke stå seg lenge mot den mer aktive nærings- og reguleringspolitikken som ledsaget økonomisk og industriell utvikling, urbanisering og nye sosiale utfordringer fra slutten av 1800-tallet. Erkjennelsen av at eksisterende rettigheter ikke kunne stå i veien for $n \varnothing$ dvendige reguleringer og politiske reformbehov, utviklet seg i et samspill mellom juridisk praksis og teori. ${ }^{122}$ To dommer var særlig sentrale. I den såkalte

\footnotetext{
${ }^{114}$ Ovenfor pkt. 2.3.ii.

115 Ofte vil man kunne se dette som et spørsmål om hvilke berettigede forventninger som er etablert, se for eksempel HR-2018-1258-A avsnitt 123 flg., og nedenfor pkt. 4.

${ }^{116}$ Se for eksempel Fredrik Stang, P.K. Gaarder og professorene Schweigaard og Motzfeldt på vegne av Det juridiske fakultet i betenkning om Det bergenske bakerlaug inntatt i Rt-1895-292, se også nærmere Knoph (1948) s. $52 \mathrm{flg}$.

117 Bugge (1999) s. 67, og Knoph (1948) s. 55.

118 Jf. Rt-1888-601.

${ }^{119}$ Aschehoug (1893) s. 109. Jf. også Morgenstierne (1909) s. 676 flg.

${ }^{120}$ Aschehoug (1893) s. 107-108, Morgenstierne (1909) s. 676.

${ }^{121}$ Se for eksempel Rt-1890-455; og se også Langeland (2005) på s. 527.

122 Viktige pådrivere i den juridiske teorien var professorene Jon Skeie og Mikal H. Lie. Se for eksempel Skeies utredning i forbindelse med innskrenkninger i alkohollovgivningen: «Om statens pligt til at yde erstatning, naar lovgivningen indskrænker eller ophæver en tidligere adgang til salg eller skjænkning av alkoholholdige drikkevarer eller stiller nye vilkaar for utøvelsen av denne virksomhed» bilag 4 til alkoholkommisionens indstilling, Kristiania 1915. Se også polemikken mot Morgenstiærne foranlediget av samme i «Grundloven og Handelslovgivningen», Oslo 1916, s. 173-221. Se også M. H. Lie, «Betenkning angående grunnlovens §§ 97 og 105 og om domstolenes myndighet til å prøve loves indre gyldighet» i St. forh. (1923) Dok nr. 13, og det
} 
store konsesjonssak slo Høyesterett fast (riktignok under dissen) at vilkåret om hjemfall i konsesjonslovgivningen for vannfall ikke var i strid med Grl. § $105 .{ }^{123} \mathrm{Og}$ i den såkalte Vauvert-dommen slo Høyesterett fast at retten under et handelsbrev til å selge vin og brennevin ikke var uangripelig. Rettigheten måtte både kunne innskrenkes og oppheves gjennom senere lovgivning. ${ }^{124}$ Den nye læren fikk sitt klareste teoretiske uttrykk gjennom Ragnar Knophs såkalte standardteori. ${ }^{125}$ I motsetning til den mer statiske rettighetsteorien fremholdt Knoph tilbakevirkningsforbudets karakter av å være en fleksibel «rettferdsstandard.» ${ }^{126}$

Vi kan oppsummere utviklingen frem til i dag som et fortsatt gjeldende utgangspunkt om at regulering må tåles - eksisterende rettigheter må i stor grad både kunne reguleres og innskrenkes, uten at det skilles klart mellom regulering av fremtidig utnyttelse og at selve rettigheten begrenses eller innskrenkes. ${ }^{127}$ Det er sterke hensyn som taler for et slikt utgangspunkt. Grunnleggende sett handler dette både om demokratihensyn og om hensynet til effektivt statsstyre for å ivareta samfunnets og fellesskapets interesser i en kompleks og omskiftelig virkelighet. Dette tilsier at lovgiver må ha stor grad av frihet til å regulere og organisere eksisterende ordninger og virksomheter, i samsvar med den aktuelle samfunnssituasjon til enhver tid. ${ }^{128}$

Dommen i gullklausulsaken kan illustrere hvordan dette har betydning som et tungt normativt utgangspunkt selv i en situasjon der klare og definerte rettigheter ble tilsidesatt. ${ }^{129}$ Gullklausulene var inntatt i svært mange låneavtaler på verdensbasis, nettopp for å beskytte kreditorene mot valutasvingninger når nasjonale valutaer ble frikoblet fra gullstandarden. Konsekvensen var at myndighetenes mulighet til å fristille pengeverdien fra gullstandarden ble drastisk redusert, med potensielt dramatiske implikasjoner. Når hensynet til å opprettholde et bærekraftig pengesystem stod mot private rettigheter måtte de private rettighetene vike. Noen ekspropriasjon var det ikke tale om. Formålet med å tilsidesette gullklausulene var ikke at samfunnet skulle tilegne seg private ressurser, men et grunnleggende regulatorisk behov.

En sentral erkjennelse som ble reflektert i gullklausuldommen, og som i dag har enda klarere rettslig forankring, er at ingen private økonomiske rettigheter kan være helt uangripelige stilt overfor tvingende samfunnsinteresser. Hensynet til å beskytte bestående rettigheter

\footnotetext{
etterfølgende tillegget (i samme publikasjon), Professor Bredo Morgenstiernes «Betenkning angående spørsmålet om ophevelse av grunnlovens § 97 og dermed sammenhengende spørsmål.

${ }^{123}$ Rt-1918-403, jf. også nærmere om dommen nedenfor pkt. 3.3.ii.

124 Rt-1922-624, jf. også nærmere nedenfor pkt. 4.2.

125 Se også Bugge (1999) s. 71 flg., med videre henvisninger.

${ }^{126}$ Knoph (1948) s. 65 flg.

127 Se særlig langt i denne retning, flertallet i Rt-2013-1345 (som også nærmere omtalt nedenfor). Dette betyr likevel ikke at en bestemt teori, som standardteorien, har fått et endelig gjennomslag og fortrengt andre tilnærminger. Bugge (1999) s. 72, observerer at «rettsregelteorien og standardteorien ikke representerer klart definerte motsetninger, men at de lar seg kombinere, og at dette skjer i praksis.»

${ }^{128}$ Under EMK P1-1 anerkjennes også dette uttrykkelig gjennom den såkalte kontrollregelen i andre ledd, jf. nedenfor pkt. 3.3.iii.

${ }^{129}$ Rt-1962-369. Se også Rt-2006-293 avsnitt 69, der førstvoterende på vegne av flertallet nettopp forankret sin oppmykning av et strengt utgangspunkt om grunnlovsstrid på en slik forståelse av gullklausuldommen.
} 
kan ikke forhindre etterfølgende regulering. Satt på spissen: hensynet til den bestående rettighet kan ikke gå lenger enn at virkningene for den private part må veies mot reguleringsbehovet i den enkelte sak, med andre ord et krav til forholdsmessighet. Dette er en grunntanke bak prinsippet om "fair balance» under P1-1. Og i lys av Høyesteretts nyere praksis må det også anses som et grunnleggende utgangspunkt for rettighetsvernet under Grl. § 97. ${ }^{130}$

Samtidig er det også andre hensyn som tvinger seg inn i dette bildet, og som kan ha betydning for både utgangspunktet for og intensiteten i den forholdsmessighetsvurderingen som skal foretas. Et hensyn er for eksempel at man bør kunne stole på og innrette seg i tillit til rettsordninger som har dette som formål, eller der man har fått konkrete tilsagn fra myndighetene. Her handler det ikke bare om å veie etablerte rettigheter mot offentlige interesser og reguleringsbehov, men også om å kreve at myndighetene opptrer konsistent, forutsigbart og i god tro. Der noen har innrettet seg i tillit til berettigede forventninger som myndighetene på denne måten har skapt eller lagt til rette for, kan det tilsi vern. Man kan se det slik at et inngrep, som i utgangspunktet har et regulerende formål, likevel får et avståelseselement, eller at vi er et steg nærmere egentlig tilbakevirkning under Grl. § 97, nettopp fordi det rokkes ved konkret og velbegrunnet forutsatte virkninger av fortidige disposisjoner og handlinger.

Det er heller ikke slik at all lovgivning aktualiserer like genuine regulatoriske behov. Et utgangspunkt er at regulering er noe kvalitativt annet enn at det offentlige tilegner seg en fordel på bekostning av bestemte individer eller grupper. Likhetshensyn og en forutsetning om at regulering innebærer generell normering i motsetning til individuelle inngrep kommer inn her. Lovgivning som sikter mot å skaffe det offentlige en fordel, eller som ikke gjelder generelt, og i stedet er rettet inn mot enkeltpersoner eller en avgrenset gruppe, kan det derfor være mindre grunn til at skal slå gjennom overfor private interesser.

Samtidig kan slike hensyn støte mot et annet viktig hensyn - demokratihensynet. Selv om man anerkjenner at domstolene kan prøve lovgivningen opp mot Grunnloven, bør det i stor grad være opp til lovgiver å avgjøre både om og når det foreligger et genuint regulatorisk behov, og om bestemte inngrep som har skadevirkninger for private parter er nødvendige og har samfunnsmessig legitimitet. ${ }^{131}$ Dette tilsier at domstolene viser en viss tilbakeholdenhet med hensyn til å overprøve Stortingets vurderinger, både med hensyn til behovet for regulering, og avveiningen mellom offentlige og private interesser. ${ }^{132}$ Men det er ikke gitt at

\footnotetext{
130 Jf. særlig Rt-2006-293 og Rt-2010-143. Høyesterett kom til at selv inngrep av regulerende art som lå nært egentlig tilbakevirkning måtte vike ved «sterke samfunnsmessige hensyn.»

131 Prøvingsretten følger i dag av Grl. § 89 men prinsippet har vært antatt nesten helt siden 1814 , se nærmere $\varnothing$ yrehagen Sunde (2015) s. $64 \mathrm{flg}$.

132 Synspunktet har en tidlig forankring i Rt-1918-403, og ble også lagt til grunn i Rt-1952-1089. Se generelt Arnulf Tverberg, «Det graderte grunnlovsvernet ved tolking av Grunnloven og prøving av lovers grunnlovmessighet» i Eirik Holmøyvik (red.), Tolkingar av Grunnlova, Oslo 2013, s. 256-303. Under EMK følger det samme av skjønnsmarginen som domstolen anvender ved fortolkning av konvensjonsrettighetene, se nærmere for eksempel Lars Oftedal Broch, «Skjønnsmarginen i nyere praksis fra Den europeiske menneskerettsdomsto|» Lov og Rett, 2005, s. 259-282.
} 
domstolene bør vise samme tilbakeholdenhet overfor lovgivers syn på tolkning av Grunnloven. Her kommer funksjonsfordelingen mellom statsmaktene inn med full styrke.

Slik man har vurdert dette i rettspraksis etter Kløfta-dommen avhenger domstolenes prøvingsadgang av en tredeling, der økonomiske rettigheter antas å komme i en mellomstilling. ${ }^{133}$ Det har imidlertid også skjedd en betydelig utvikling og nyansering av synet på prøvingsintensiteten. Førstvoterende i Kløfta-dommen tok som utgangspunkt «at Stortingets forståelse av lovens forhold til slike grunnlovsbestemmelser må spille en betydelig rolle når domstolene skal avgjøre grunnlovmessigheten, og domstolene må vise varsomhet med å sette sin vurdering over lovgiverens. ${ }^{134}$ Dette tilsa at Stortingets vurdering burde tillegges avgjørende vekt «hvor det foreligger rimelig tvil, og hvor Stortinget klart har vurdert og bygd på at loven ikke kommer i strid med grunnloven.» ${ }^{135}$ Også i senere dommer har Høyesterett bygget på dette utgangspunktet, som innebærer at domstolene bør tillegge Stortingets vurderinger større vekt der det er tale om å gripe inn i økonomiske rettigheter enn ved inngrep i den personlige frihet og sikkerhet. ${ }^{136}$

I senere praksis må likevel disse utgangspunktene anses vesentlig nyansert. Både hvilke vurderinger det er tale om å overprøve og hva slags økonomiske rettigheter det er tale om vil ha betydning. ${ }^{137}$ I Borthen-dommen fremholdt førstvoterende «hensynet til lovgivers handlefrihet» på det aktuelle område som sentralt. ${ }^{138}$ Forutsetningen synes å ha vært at dette hensynet kan ha ulik vekt ved ulike kategorier økonomiske rettigheter. En alminnelig tendens etter Borthen-dommen synes videre å være at «Høgsterett stiller klarare og strenge krav til Stortingets grunnlovsvurdering. " ${ }^{139}$ Både i Øvre Ullern Terrasse-, ${ }^{140}$ og senere i rederiskatt-dommen la Høyesterett til grunn at det måtte stilles et «kvalitetskrav» til Stortingets vurderinger. ${ }^{141}$ Synspunktet synes nettopp å ha vært at det er mindre grunn til å

\footnotetext{
133 Rt-1976-1, på s. 5-6: «Løsningen vil i noen grad avhenge av hvilke grunnlovsbestemmelser det er tale om. Gjelder det bestemmelser til vern om enkeltmenneskets personlige frihet eller sikkerhet, antar jeg at grunnlovens gjennomslagskraft må være betydelig. Gjelder det på den annen side grunnlovsbestemmelser som regulerer de andre statsmakters arbeidsmåte eller innbyrdes kompetanse, mener jeg som førstvoterende i plenumssaken inntatt i Rt-1952-1089, særlig side 1098 (hvalavgiftssaken), at domstolene i vid utstrekning må respektere Stortingets eget syn. Grunnlovsbestemmelser til vern om økonomiske rettigheter må for så vidt komme i en mellomstilling.»

134 Ibid. s. 6

135 Ibid.

${ }^{136}$ Tverberg (2013), s. s 272; og Tverberg (2021), særlig pkt. 5.2 og 5.3; og se også Øyrehagen Sunde (2015) s. $211 \mathrm{flg}$.

${ }^{137}$ Enkelte har også stilt spørsmål ved om det fortsatt er grunnlag for å opprettholde et skille mellom $\varnothing$ konomiske og andre individuelle rettigheter, se Skoghøy (2011) s. 280, og Tverberg (2013) s. 292 med ytterligere henvisninger.

138 Rt-1996-1415 på s. 1429.

${ }^{139}$ Eirik Holmøyvik, «Prøvingsrett og tilbakeverknadsforbod: Borthen-dommen i Rt-1996-1415 og rettsutviklinga», i Rettsavklaring og rettsutvikling: Festskrift til Tore Schei, Universitetsforlaget 2016 s. $210-242$, på s. 222.

140 Rt-2007-1281, avsnitt 76.

${ }^{141}$ Rt-2010-143 avsnitt 172-173: «Eg har så langt ikkje gått inn på verknadene av Stortinget sitt syn. I denne saka har Stortinget gjort ei svært grundig vurdering av grunnlovsspørsmålet, og i innstillinga frå finanskomiteen er det utførlege drøftingar og vurderingar. For at Stortinget sitt syn skal innebere at prøvingsretten skal
} 
tillegge Stortingets vurderinger vekt der $\mathrm{H} \varnothing$ yesterett er uenig i selve grunnlovstolkningen. ${ }^{142}$ Synspunktene i rederiskatt-dommen tilsier videre at graden av inngrep, vil ha betydning for hvilken vekt Stortingets vurderinger må tillegges. Ved særlig omfattende inngrep som ligger tett opp til egentlig tilbakevirkning kan det være mindre grunn til å tillegge Stortingets vurderinger særlig vekt, særlig hvor uenigheten knytter seg til hvilken avveiningsnorm som kommer til anvendelse.

Dette spørsmålet om hvor langt domstolene kan og skal gå i sin prøving har dermed også en viktig side til valg av prøvingsnorm og spørsmålet om et skjerpet forholdsmessighetskrav. I kravet til at det må foreligge et klart uforholdsmessig inngrep (jf. nedenfor) for å konstatere grunnlovsstrid, ligger nettopp at domstolene må vise tilbakeholdenhet. Det alternative utgangspunktet, der grunnlovsstrid konstateres med mindre det foreligger sterke samfunnsmessige hensyn, innebærer derimot en mer intensiv domstolsprøving.

\subsection{Nærmere om unntaket for klart uforholdsmessige inngrep}

At regulering må tåles betyr at eksisterende rettighetsposisjoner som utgangspunkt ikke er beskyttet mot etterfølgende regulatoriske inngrep. Både under Grl. §§ 97 og 105, og under EMK P1-1, har det utkrystallisert seg parallelle utgangspunkter om at eksisterende rettigheter kun er beskyttet mot klart uforholdsmessige inngrep. Selv om dette er formulert litt ulikt under de ulike bestemmelsene, er de grunnleggende vurderingstemaene som vi skal se nærmere på nedenfor ikke fundamentalt forskjellige.

\section{i. Grl. § 97 - «klart urimelig eller urettferdig»-normen}

Under Grl. § 97 finner vi igjen mye av essensen av Knophs standardteori i det rådende synspunkt om at Grl. § 97 ikke forbyr såkalt uegentlig tilbakevirkning, eller regulering av rettsforhold for fremtiden, med mindre dette vil virke «klart urimelig eller urettferdig» i den enkelte sak. Formuleringen ble introdusert i Borthen-dommen, ${ }^{143}$ og er senere anvendt flere ganger. ${ }^{144}$ I Borthen uttalte førstvoterende følgende om avveiningstemaet:

«Inn i avveiningen vil blant annet komme hvilke rettigheter eller posisjoner inngrepet gjelder, hvilket grunnlag den enkelte eller en gruppe har for sine forventninger, om inngrepet er plutselig og betydelig og om fordelingen av byrdene rammer den enkelte eller en gruppe særlig hardt. 1 $^{145}$

\footnotetext{
avgrensast i tvilstilfelle, jf. førstvoterande i dommen i Rt-2007-1308 (Sørheim), må det stillast eit kvalitetskrav. Det inneber at Stortinget må ha lagt til grunn eit relevant prøvingstema og vore merksam på vesentlege konsekvensar av ei lov. Når det av Stortinget er gjort ei prøving ut frå ei anna norm for grunnlovsprøving enn den eg meiner må nyttast, gjer det at det er vanskeleg å leggje vekt på sjølve interesseavveginga hos Stortinget. Ut frå den norma eg har lagt til grunn, er grunnlovsspørsmålet etter mitt syn ikkje tvilsamt.» ${ }^{142}$ Se kritisk, Stig Solheim, «Domstolskontroll med lov på det økonomiske området - lovgivers vurdering av lovens grunnlovsmessighet», Tidsskrift for rettsvitenskap, 2014, s. 1-48, på s. 17-18.

143 Jf. Rt-1996-1415 på s. 1430.

${ }^{144}$ Se for eksempel HR-2016-389-A, Rt-2013-1345, Rt-2006-262 og Rt-1996-1440.

145 Rt-1996-1415 på s. 1430.
} 
At vurderingstemaet gjøres til et spørsmål om hva som er rimelig eller rettferdig, har blitt kritisert i teorien, blant annet av Høgberg, som hevder det reduserer standardteoriens helhetsvurdering til «et narrespill som ingen andre enn lovgiver kan vinne.» ${ }^{146}$ Uten noe mer presist kriterium vil Høyesterett i praksis ikke kunne sette seg ut over Stortingsflertallets syn hevdes det, og realiteten med et slikt kriterium er dermed langt på vei at rettigheter ikke har noe vern. ${ }^{147} \mathrm{H} \varnothing$ gbergs syn er at rettighetsvernet under Grl. $\S 97$ bedre kan angis som en åpnere, helhetlig interesseavveining og forholdsmessighetsvurdering, ${ }^{148}$ hvor flere momenter, herunder hvor tyngende inngrepet er for den enkelte, og hvor $n \varnothing d v e n d i g$ inngrepet fremstår utfra aktuelle offentlige interesser, må avveies mot hverandre. ${ }^{149}$

At «klart urimelig eller urettferdig»-kriteriet medfører et «svakt» grunnlovsvern er det åpenbart noe i. Men samtidig kan man innvende at det jo også er meningen. Det følger av de hensynene som tilsier at lovgiver $b \varnothing r$ ha stor grad av frihet. Samtidig er det også et spørsmål om det er riktig at normen som ble anvendt i Borthen-dommen ikke forutsetter en reell interesseavveining. ${ }^{150}$ Førstvoterende avviser klart nok ikke at det skal foretas en interesseavveining, ${ }^{151}$ det han derimot avviser er vilkåret om «en 'dominerende' offentlig interesse for at lovvedtaket skal stå seg», som hadde blitt lagt til grunn av lagmannsretten. ${ }^{152}$

Formuleringen av «klart urimelig og urettferdig»-kriteriet synes her primært å reflektere en høyere terskel for å konstatere grunnlovsstrid, basert på et utgangspunkt om handlefrihet for lovgiver som innebærer at domstolene $b \varnothing r$ vise tilbakeholdenhet. ${ }^{153}$ Terskelen b $\varnothing r$ være høy for å karakterisere i alle fall tilsiktede virkninger av Stortingets lovgivning som uforholdsmessig. Istedenfor å stille lovgivningen overfor et positivt krav til forholdsmessighet, snus dermed utgangspunktet. Presumsjonen er at lovgiver kan regulere. Det må derfor kreves et kvalifisert misforhold for å konstatere grunnlovsstrid.

\footnotetext{
146 Høgberg (2010) s. 322, og se også Skoghøy (2011) på s. 272-273; og Eivind Smith, «Grunnloven § 97: En eller to hovedregler?» Lov og Rett (2013) s 488-499, på s. 490-491.

${ }^{147}$ Synspunktet synes først hevdet av høyesterettsdommer Tjomsland, i hans særvotum i Borthen-dommen, se Rt-1996-1415 på s. 1436. Se slik også Smith (2013), som argumenterer for at dette også bør være utgangspunktet.

148 Ibid. s. 317.

149 Ibid. s. 324 flg.

${ }^{150}$ Se særlig Benedikte Moltumyr Høgberg, «Grunnloven § 97 etter plenumsdommen i Rt. 2010 s. 143» på s. 706; og se også Høgberg (2010) s. 291 og s. 299 flg.

151 Jf. formuleringen av avveiningskriteriene på s. 1430, som sitert over i tilknytning til note 27, og slik også for så vidt Høgberg (2010) på s. 300 om den konkrete vurderingen i Borthen-dommen. Høgbergs kritikk kan dermed primært synes å være en kritikk av at normformuleringen ikke klart indikerer at det er tale om en forholdsmessighetsvurdering, noe som åpenbart har noe for seg.

152 Rt-1996-1415 på s. 1431: "[J]eg kan ikke se at det er holdbart fra dette generelle utgangspunktet å slutte at Grunnloven $\S 97$ her er en interesseavveiningsregel på den måten at det offentliges interesser skal måtte vike når de ikke overstiger - eventuelt «markert» eller «åpenbart» - de interesser som blir skadelidende ved den nye lovgivning»

153 Ibid. s. 1431: «Som påpekt er vi på et område hvor lovgiver har behov for og - etter forutsetningene bak Grunnloven $\S 75$ bokstav a og d - skal ha en betydelig handlefrihet. Anvendelsen av standarden må reflektere også dette, og selv om pensjonistenes interesse i trygghet for levestandard er viktig, kan jeg ikke se at den når lenger enn til en beskyttelse mot det klart urimelige eller urettferdige.»
} 
Også senere praksis som har anvendt normen forutsetter at det må foretas en interesseavveining. ${ }^{154}$ I plenumsdommen i Rt-2013-1345 (strukturkvote) antok førstvoterende at normen innebar en forholdsmessighetsvurdering med utgangspunkt $i$ «hvordan inngrepet rammer den enkelte». ${ }^{155}$ Og en enstemmig rett i HR-2016-389-A (Carl I Hagen) som er den siste som har anvendt normen, forutsatte at det «uavhengig av normvalg må skje en avveining mellom de vernede interesser på den ene siden, og de samfunnsmessige hensynene på den annen.» ${ }^{156}$

En mer presis formulering av «klart urimelig eller urettferdig»-normen kan dermed være at det er de kvalifisert eller klart uforholdsmessige inngrep som rammes. Imidlertid er det som vi kommer tilbake til nedenfor et åpent spørsmål om normen gjelder alle rettighetsinngrep, eller om visse, omfattende rettighetsinngrep aktualiserer et skjerpet forholdsmessighetskrav. ${ }^{157}$

\section{ii. Rådighetsinnskrenkninger under Grl. § 105 - «sterkt urimelig»-kriteriet}

Parallelt med standardteoriens gjennomslag under Grl. § 97 etablerte den oppfatning seg som fortsatt er rådende i dag, om at Grl. § 105 ikke beskytter mot rådighetsinnskrenkninger. Det som gjør dette til et sterkt, normativt utgangspunkt for fortolkningen av Grl. § 105, er sammenstillingen med et funksjonelt eller negativt eiendomsrettsbegrep - altså et syn på eiendomsretten som primært en funksjon av lovgivningen til enhver tid, uten noen egen «substans». Kombinasjonen var intellektuelt sprengstoff som banet vei for den moderne reguleringsstaten.

En sentral dom er den tidligere nevnte konsesjonssaken fra 1918. Høyesterett fant at vilkåret om hjemfallsrett ikke utgjorde ekspropriasjon, selv om det uomtvistet reduserte verdien av eiendommene. ${ }^{158}$ Senere, i Strandlovdommen, bygget Høyesterett direkte på synspunktene

\footnotetext{
${ }^{154}$ Rt-2006-262 er riktignok vanskelig å se som utslag av noen reell interesseavveining. Førstvoterende synes blant annet uttrykkelig å avvise at inngrepets konkrete virkninger hadde særlig betydning. Han var enig i at inngrepet rammet enken hardt (dommen, avsnitt 88) «på bakgrunn av et 25 års ekteskap, der hun også har hatt ansvar for tre barn frem til voksen alder, og ved sin innsats i hjemmet har bidratt til ektefellens opptjening av pensjon i SPK.» Synspunktet i dommen synes primært begrunnet utfra at selve rettigheten ikke ble ansett spesielt beskyttelsesverdig. Jf. også Rt-2007-1281 ( $\varnothing$ vre Ullern) hvor retten ikke viste til «klart urimelig og urettferdig»-normen, men synes å ha lagt til grunn at det avgjørende var en «helhetsvurdering» og interesseavveining». Her var det imidlertid tale om et omfattende inngrep med klare avståelseselementer, hvor Norge senere ble dømt i EMD, jf. Lindheim v. Norway, No. No. 13221/08 og 2139/10 (2012), og jf. også nærmere nedenfor pkt. 3.3.iii.

155 Rt-2013-1345 avsnitt 99: «Hvordan inngrepet rammer den enkelte, kommer - som jeg nettopp har framholdt - inn ved den konkrete forholdsmessighetsvurderingen, som naturlig inngår i avgjørelsen av om inngrepet er særlig urimelig eller urettferdig.»

156 HR-2016-389-A, avsnitt 77.

${ }^{157}$ I noen situasjoner kan det vel også tenkes, forsåvidt i samsvar med EMDs tilnærming til disse spørsmålene, at det ikke er grunn til å oppstille noe helt klart utgangspunkt - altså at utgangspunktet bør være en åpnere forholdsmessighetsvurdering.

${ }^{158}$ Rt-1918-403 særlig s. 405: «Eiendomsretten til en gjenstand er efter en formentlig fastslaat definition retten til at raade over sin eiendom med de almindelige indskrænkninger, som flyter umiddelbart av loven eller retsordenen.» Jf. også tredjevoterende i byretten, assessor Siewers' votum, som flertallet i Høyesterett sluttet seg til.
} 
fra konsesjonssaken. Den nye strandloven, som innførte byggeforbudet i strandsonen, ble ansett ikke å gi krav om erstatning, selv om den medførte et totalt byggeforbud og betydelig verdiforringelse for en holme som ikke på noe sted hadde mer enn 100 meter til sjøen. ${ }^{159}$ Strandlovdommen gjaldt en helt alminnelig regulering, men $\mathrm{i}$ en rekke senere dommer $\mathrm{i}$ saker om naturvernregulering har Høyesterett også gått langt i å akseptere at selv individuelle rådighetsinnskrenkninger begrunnet i naturvernhensyn ikke gir krav om erstatning. ${ }^{160}$ Det samme synspunktet er også reflektert i en rekke dommer som, med få og spesifikke unntak, legger til grunn at gjeldende reguleringsplan er styrende for hva som utgjør påregnelig bruk når det skal utmåles erstatning ved ekspropriasjon. ${ }^{161}$ | Rt-2005-469 (og med henvisning til sin tidligere dom i Rt-2004-1092) oppsummerte Høyesterett kravene til erstatningsansvar ved rådighetsinnskrenkninger under Grl. § 105 som «at det ikke er tilstrekkelig for erstatningsansvar at det dreier seg om et vesentlig inngrep. Inngrepet må ha en slik karakter at det ut fra en helhetsvurdering fremstår som sterkt urimelig om det skal tåles. ${ }^{162}$

Som vi skal se nedenfor løser likevel ikke dette kriteriet spørsmålet om det foreligger rådighetsinnskrenkning eller avståelse i en konkret sak. Vi får en parallell til forholdet mellom kriteriene «klart urimelig eller urettferdig» og "sterke samfunnsmessige hensyn» under Grl. § 97. Spørsmålet er om visse inngrep, som riktignok har et regulerende siktemål, likevel kan medføre elementer av avståelse (eller delvis avståelse) som aktualiserer et sterkere utgangspunkt om beskyttelse også under Grl. § 105. ${ }^{163}$

\section{iii. «Kontrollregelen» under EMK P1-1}

Grunntrekkene av rettighetsvernet under P1-1, slik det er blitt utviklet av menneskerettighetsdomstolen, ligner til forveksling på utgangspunktene som følger av henholdsvis Grl. §§ 105 og 97. Man kan litt løselig se det slik at det er kontrollregelen, modifisert av den overordnede prinsippregelen og dens krav til at inngrep må være forholdsmessige, som i hovedsak tilsvarer reguleringsvernet under Grl. §§ 97 og 105. Også vurderingstemaene fremstår temmelig like; vurderingen av om det foreligger en «disproportionate and excessive burden» er ikke nødvendigvis så forskjellig fra vurderingen av om noe er "klart urimelig eller urettferdig» eller «ut fra en helhetsvurdering fremstår som sterkt urimelig».

I de norske formuleringene ligger riktignok et krav om kvalifisert misforhold eller urimelighet, som ikke følger av EMDs formulering. Men i praksis virker det ikke å være noen vesentlig forskjell. At misforholdet må være «klart» reflekterer at domstolene bør vise tilbakeholdenhet med å overprøve lovgivning som griper inn i økonomiske rettigheter. ${ }^{164}$

\footnotetext{
${ }^{159}$ Rt-1970-67, på s. 70-71.

${ }^{160}$ Rt-2005-469, Rt-2004-1092, Rt-1994-813, Rt-1993-321, Rt-1993-1333, Rt-1989-1339, Rt-1988-890, Rt-198851, Rt-1987-80, Rt-1987-311, Rt-1982-850, Rt-1980-94.

161 Jf. ekspropriasjonserstatningsloven §§ 5 og 6, og Rt-1996-521, Rt. 1994-1123, Rt-1993-496, Rt-1993-409, Rt1993-166, Rt-1992-55, Rt-1990-410, Rt-1984-1331, Rt-1983-700, Rt-1977-24, Rt-1976-464, Rt-1976-1.

162 Rt-2005-469, avsnitt 29.

163 Jf. nedenfor pkt. 4.3.

${ }^{164}$ Rt-1996-1415 på s. 1429-1430, og Rt-2006-293 avsnitt 68.
} 
Også under EMK står dette utgangspunktet sterkt, og på grunn av den statlige skjønnsmarginen vel enda sterkere enn under norsk rett. ${ }^{165}$ Normalt vil det være en forholdsvis høy terskel for å finne at et inngrep er uforholdsmessig hvis vi først er i kontrollregelen. ${ }^{166}$ I storkammersaken JA Pye v. UK uttalte EMD følgende om forholdsmessighetsvurderingen under kontrollregelen:

"In respect of interferences which fall under the second paragraph of Article 1 of Protocol No. 1, with its specific reference to "the right of a State to enforce such laws as it deems necessary to control the use of property in accordance with the general interest ...", there must also exist a reasonable relationship of proportionality between the means employed and the aim sought to be realised. In this respect, States enjoy a wide margin of appreciation with regard both to choosing the means of enforcement and to ascertaining whether the consequences of enforcement are justified in the general interest for the purpose of achieving the object of the law in question. ${ }^{167}$

Fra kontrollregelen kan det likevel ikke utledes noen presumsjon om at alle andre rettighetsinngrep enn avståelse aktualiserer utgangspunktet om frihet til å regulere som følger av kontrollregelen. Domstolen opererer med en kategori av tilfeller som verken anses som avståelse eller regulering/kontroll, hvor «fair balance»-prinsippet i første setning gjelder direkte uten mellomkomst av utgangspunktene som følger av de to $\varnothing$ vrige reglene. ${ }^{168} \mathrm{Her}$ vil dermed ikke avveiningsnormen i samme grad være presumsjonsbasert, og det kan virke som domstolen heller tar utgangspunkt i en konkret vurdering av hvor inngripende det aktuelle tiltaket er, og om det reelt sett ligger nærmere kontroll eller avståelse. ${ }^{169}$ Regulatoriske inngrep i andre typer rettigheter enn eiendom, som pensjonsrettigheter, synes ofte å aktualisere prinsippregelen direkte. ${ }^{170}$ Videre er det blitt observert å være en tendens at domstolen i økende grad avstår fra å kategorisere inngrep som avståelse eller kontroll, og i stedet anvender prinsippregelen direkte. ${ }^{171} \mathrm{I}$ dette ligger egentlig at domstolen avstår fra å anvende noen presumsjon for inngrep som ikke lett lar seg kategorisere som enten regulering eller avståelse.

Likevel ser man både i disse tilfellene, og ved tilfeller som faller under kontrollregelen, at forholdsmessighetsvurderingen noen ganger kvalifiseres av et begrep om berettigede forventninger. ${ }^{172}$ Der inngrepet går langt i å rokke ved en berettiget forventning hos den private part er det inngrepet som krever en særskilt begrunnelse for å være forholdsmessig. Dette er godt illustrert av Lindheim-dommen mot Norge, hvor domstolen resonnerte som

\footnotetext{
${ }^{165}$ Se om skjønnsmarginen under EMK, Harris, O’Boyle and Warbrick (2018) s. 884 flg.

166 Solheim (2010) s. 89.

167 JA Pye v. UK, No. 44302/02 (2007), avsnitt 55.

168 Harris, O'Boyle and Warbrick (2018) s. 869 flg.; og Solheim (2010) s. 70-71.

169 Solheim (2010) s. 90-91.

170 Ibid. s. 871.

171 Harris, O’Boyle and Warbrick (2018) s. 863; og Solheim (2010) s. 73-74.

172 Dette begrepet brukes riktignok primært av domstolen som et sentralt element ved fastleggelsen av om det foreligger en beskyttet rettighet men vil også ha betydning i selve proporsjonalitetsvurderingen, se generelt Solheim (2010) s. 218 flg, og om betydningen av begrepet i proporsjonalitetsvurderingen s. 303-305.
} 
følger for å konkludere med at den daværende regelen i festelovgivningen om rett til forlengelse uten justering av festeavgiften var uforholdsmessig:

"The Court accepts however that the applicants could entertain a legitimate expectation that the relevant lease contracts would expire as agreed according to their terms, independently of the intervening discussions on and adoption of legislative measures. (...) In these circumstances, it does not appear that there was a fair distribution of the social and financial burden involved but, rather, that the burden was placed solely on the applicant lessors (...) The Court is therefore not satisfied that the respondent State, notwithstanding its wide margin of appreciation in this area, struck a fair balance between the general interest of the community and the property rights of the applicants, who were made to bear a disproportionate burden. ${ }^{173}$

Man ser også dette resonnementet ved inngrep i konsesjoner og lignende offentligrettslige tillatelser til næringsvirksomhet. Slike rettigheter utgjør normalt en «possession» under P11. ${ }^{174}$ Men selv der inngrepet innebærer full tilbaketrekning eller tap av tillatelsen er aktualiserer dette normalt kontrollregelen og ikke avståelsesregelen. ${ }^{175}$ Dette reflekterer at en offentlig tillatelse eller konsesjon selv er et regulatorisk instrument, og dermed ikke er eiendom i tradisjonell forstand. Derimot må de ofte ses som aksessoriske til andre eiendomsrettigheter, i det at konsesjonen gir en regulatorisk skapt rett til å utnytte eiendom eller eksisterende innretninger på en bestemt måte. ${ }^{176}$ Tillatelsen vil altså typisk kunne innebære at det foreligger en berettiget forventning med krav på vern. ${ }^{177}$ Særlig dersom inngrepet innebærer at tillatelsen trekkes tilbake, synes det som om domstolen ser det slik at inngrepet får et element av avståelse som aktualiserer et skjerpet forholdsmessighetskrav. I Werra Naturstein-saken så for eksempel domstolen dette som et

\footnotetext{
173 Lindheim v. Norway, App 13221/08 og 2139/10 (2012), avsnitt 133-134.

174 Werra Naturstein Gmbh \& co KG, v. Germany, No. $32377 / 12$ (2017); Vékony v. Hungary No. 65681/13 (2015); Centro Europa 7 s.r.l. and di Stefano v. Italy, No. 38433/09 (2012); Fredin v. Sweden, No. 12033/86 (1991); Tre Traktörer AB v. Sweden, No. 10873/84 (1989).

${ }^{175}$ Vékony v. Hungary No. 65681/13 (2015), avsnitt 30; Tre Traktörer AB v. Sweden, No. 10873/84 (1989), avsnitt 55.

176 HR-2018-1258-A avsnitt 121-123; Tre Traktörer AB v. Sweden, No. 10873/84 (1989), avsnitt 55; og Fredin v. Sweden, No. 12033/86 (1991), avsnitt 42-47.

177 Jf. Werra Naturstein Gmbh \& co KG, v. Germany, No. 32377/12 (2017), avsnitt 51-52: “[T]he applicant company in the present case was not only prevented from further developing its property. There was an interference in a separate right other than to the land, as the applicant company had also been granted a mining licence for twenty-five years and had been able to extract only one third of the deposit. (...) It is worth noting that the mining authority was or could have reasonably been aware of the planned motorway when granting the licence. It issued the licence despite the uncertainty as to where exactly the motorway would be built and how the quarrying operation would be affected." Og motsetningsvis Fredin v. Sweden, No. 12033/86 (1991), avsnitt 53-55, hvor domstolen kom til at retten til å ut $\varnothing v e$ virksomheten i samsvar med den tillatelsen som engang var blitt gitt fremstod som så usikker i lys av alle sakens omstendigheter at rettighetshaverne ikke hadde hatt grunn til å stole på den.
} 
spørsmål om det forelå «exceptional circumstances» som kunne begrunne at det ikke ble gitt erstatning. ${ }^{178}$

\subsection{Gjelder «sterke samfunnsmessige hensyn»-normen rettigheter?}

Som allerede nevnt har også Høyesterett introdusert et skjerpet forholdsmessighetskrav for visse inngrep under Grl. §97, nærmere bestemt kravet til «sterke samfunnsmessige hensyn». Spørsmålet som skal drøftes her er om normen får anvendelse på rettighetsinngrep.

Flertallet i strukturkvotedommen la til grunn at «sterke samfunnsmessige hensyn»-normen nettopp ikke gjelder "fremtidig endring av en etablert rettsposisjon» eller "regulering av et oppnådd gode». ${ }^{179}$ Førstvoterende fremholdt i stedet normen som en underkategori av den egentlige tilbakevirkning - «egentlig tilbakevirkning på det økonomiske området» - som gjelder der det knyttes « $\varnothing$ konomiske byrder til en tidligere handling. ${ }^{180}$

Dommen er imidlertid avsagt under sterk dissens (9-8). ${ }^{181}$ Mindretallet fant at inngrepet aktualiserte «sterke samfunnsmessige hensyn»-normen fordi fiskebåtrederens disposisjoner var ment tilskyndet gjennom å gi den retten - strukturkvoten - som det var grepet inn. ${ }^{182}$ Dommen reflekterer altså en uenighet der Høyesterett er delt nesten på midten i spørsmålet om hva grunnlovsnormen går ut på ved omfattende rettighetsinngrep. Mens flertallets syn er at alle rettighetsinngrep er uegentlig tilbakevirkning som aktualiserer «klart urimelig eller urettferdig»-normen, fremholder mindretallet at også inngrep i rettigheter kan medføre ulik grad av tilbakevirkning. Særlig der det gripes inn i rettigheter som er et resultat av tillitsbasert innrettelse (som den aktuelle strukturkvoten), er vi nær egentlig tilbakevirkning og kjernen av tilbakevirkningsforbudet. I så fall er utgangspunktet at det må kreves en særlig begrunnelse for at inngrepet skal være rettmessig; det må foreligge «sterke samfunnsmessige hensyn».

Rettspraksis før strukturkvotedommen kan tas til inntekt for begge posisjoner. «Sterke samfunnsmessige hensyn»-normen ble i sin nåværende form introdusert i Arves trafikkskole. Førstvoterende dommer $\varnothing i$ to tok utgangspunkt i den tradisjonelle «regelteorien» anvendt $\mathrm{i}$ skatteretten, om at Grl. § 97 «som hovedregel forbyr å legge nye skattebyrder på bestemte tidligere handlinger.» ${ }^{183}$ Vurderingskriteriet "sterke samfunnsmessige hensyn» introduserte hun som en oppmykning av denne normen, blant annet under henvisning til tredelingen $\mathrm{i}$

\footnotetext{
178 Jf. Werra Naturstein Gmbh \& co KG, v. Germany, No. 32377/12 (2017), avsnitt 53-57, og jf. også Vékony v. Hungary No. 65681/13 (2015), avsnitt 35.

${ }^{179}$ Rt-2013-1345 avsnitt 99: «Vår sak gjelder framtidig endring av en etablert rettsposisjon - istedenfor å få beholde strukturkvotene så lenge som grunnkvotesystemet gjelder, faller disse bort etter 25 år. Det er altså ikke spørsmål om å knytte byrder til tidligere handlinger, men om regulering av et oppnådd gode.» $180 \mathrm{lbid}$. avsnitt 86.

${ }^{181}$ Holmøyvik (2016), på s. 238, går dermed langt når han påstår at strukturkvotedommen avklarer «tvilen om vurderingsnorma.»

182 Dommer Normanns votum, særlig avsnitt 194-197, og dommer Skoghøys votum, avsnitt 243.

183 Rt-2006-293 særlig avsnitt 64-67.
} 
Kløfta-dommen hvor $\varnothing$ konomiske rettigheter er en mellomkategori. ${ }^{184}$ Dette tilsa at det måtte finnes «mellomvarianter mellom et absolutt forbud og en helhetsvurdering hvor bare den særlig urimelige og urettferdige tilbakevirkning er forbudt. ${ }^{185}$ Samtidig viste hun til gullklausul-dommen, der «omfattende private økonomiske rettigheter måtte vike for tvingende samfunnsinteresser» som et eksempel på en slik mellomvariant. ${ }^{186}$

Resonnementet tilsier at normen ble antatt å gjelde også for omfattende rettighetsinngrep. I gullklausulsaken var situasjonen som nevnt at en lov satte til side klausuler i låneavtaler der staten var debitor, ment å sikre mot reduksjon av pengeverdien. ${ }^{187}$ Retten sier riktignok ikke direkte at utgangspunktet var at rettighetene var beskyttet, men dette synes klart å ha vært forutsetningen for synspunktet at gullklausulene ikke kunne kreves oppfylt når dette var $\mathrm{i}$ strid med «samfunnets vitale interesser.» ${ }^{188}$

Et sentralt poeng i Arves trafikkskole synes i det hele tatt å ha vært at rettighetsperspektivet og handlingsperspektivet ikke er gjensidig utelukkende. Et inngrep kan på en og samme tid anses både som et rettighetsinngrep og som at det knyttes nye og inngripende virkninger til eldre handlinger:

«I vår sak er Arves Trafikkskole fratatt en økonomisk rettighet. I sin virkning dreier det seg om å knytte økonomiske byrder til en tidligere handling. Man er da på et område hvor Grunnlovens tilbakevirkningsforbud står sterkt, men ikke i forbudets innerste kjerne. Etter mitt syn kan man ikke på dette området stille opp et absolutt forbud mot tilbakevirkning. Men fordi man er så nær kjerneområdet til § 97, må det mye til før en tilbakevirkning kan godtas. ${ }^{189}$

I rederiskattdommen anvendte flertallet igjen «sterke samfunnsmessige hensyn»-normen for å sette til side kravet om oppgjør av latente skatteplikter under den gamle rederiskatteordningen ved overgangen til et nytt skatteregime. ${ }^{190}$ Førstvoterende oppsummerte utgangspunktene som følger:

«Ut frå rettspraksis kan det etter mitt syn stillast opp nokre hovudpunkt. Spørsmålet om ei lov som knyter verknader til tidlegare hendingar eller grip inn i etablerte rettsposisjonar, er i strid med Grunnlova §97, er avhengig av kor sterkt tilbakeverknadselementet er. Dersom lova direkte knyter tyngjande rettsverknader til eldre hendingar, er lova som hovudregel grunnlovsstridig. Om lova derimot berre gir reglar om korleis ein etablert rettsposisjon skal ut $\varnothing$ vast for framtida, er hovudregelen den motsette. Mellom desse ytterpunkta finst det

\footnotetext{
${ }^{184}$ Ibid. avsnitt 68. Mindretallet på fire anført av dommer Rieber-Mohn, jf. dommen avsnitt 100, synes derimot å ha basert seg på en åpnere avveiningsnorm «hvor også mindre tungtveiende samfunnshensyn kan gi grunnlag for å akseptere tilbakevirkningen.»

185 Ibid. avsnitt 69.

186 Ibid. avsnitt 69.

${ }^{187}$ Rt-1962-369.

188 Ibid. s. 385: «En norsk borger eller en utlending som har knyttet sin fordring til landets pengeenhet, kan ikke ha krav på å få oppfylt et kontraktvilkår av denne art mot samfunnets vitale interesser, det er ikke slike forhold Grunnlovens $\S 97$ sikter til med sitt forbud mot å gi lover tilbakevirkende kraft.»

189 Rt-2006-293, avsnitt 70.

190 Rt-2010-143.
} 
overgangsformer. I vår sak står vi overfor ei slik overgangsform. Og vi er i ein tilbakeverknadssituasjon som har klare parallellar med tilfellet i Arves Trafikkskole.»1 ${ }^{191}$

Også i denne dommen var det sterk dissens (6-5). Mye av uenigheten mellom flertallet og mindretallet handlet nettopp om kategoriseringen av inngrepet. Mens flertallet fremholdt hvordan overgangsordningen skjerpet skatteplikten for tidligere handlinger, ${ }^{192}$ tok mindretallet som utgangspunkt at det var tale om et inngrep i en etablert rettsposisjon. ${ }^{193}$ Likevel er det mye som taler for at i alle fall flertallets syn i dommen ikke kan tas til inntekt for et slikt skarpt skille mellom handlinger og rettigheter som flertallet $\mathrm{i}$ strukturkvotedommen la til grunn. Synspunktet var jo nettopp at man stod overfor en overgangsform mellom ytterpunktene nye «tyngjande rettsverknader til eldre hendingar» og «reglar om korleis ein etablert rettsposisjon skal utøvast for framtida.»194

Uenigheten mellom flertall og mindretall i rederiskattesaken illustrerer dermed også at skillet mellom egentlig og uegentlig tilbakevirkning ikke nødvendigvis er gjensidig utelukkende. Det var mulig å se omdanningen av skattekreditten både som et inngrep i en etablert rett til skattefrihet, og som at det ble knyttet skattebyrder til disposisjoner som var (betinget) skattefrie da de ble utført. Sentralt i begrunnelsen for et skjerpet krav til forholdsmessighet synes uansett å ha vært mer substansielle betraktninger knyttet til berettigede forventninger og innrettelse under det eksisterende regelverket. ${ }^{195}$

Dette tilsier at skillet mellom handlinger og rettigheter ikke nødvendigvis forutsetter et normvalg så mye som å reflektere to motstående og gjensidig supplerende utgangspunkter under en felles avveiningsnorm. Det første utgangspunktet er at «rene» rettigheter i liten grad er beskyttet mot fremtidig regulering. Grl. § 97 beskytter ikke rettigheter som sådan den beskytter mot at en lov virker tilbake, altså at det i dag knyttes andre mer tyngende virkninger til en handling eller begivenhet i fortiden enn det som da gjaldt. Men også en rettighet er et resultat av og grunnlag for bestemte handlinger eller disposisjoner. Hvis lovgivningen i dag griper inn i og endrer virkninger av disposisjoner i fortiden, særlig konkrete og spesifikke virkninger som de aktuelle disposisjonene hadde til hensikt å oppnå, får inngrepet sterkere preg av egentlig tilbakevirkning. Det gripes inn i konkret forutsatte virkninger av fortidige handlinger. Her er vi i kjernen av det som er formålet med Grl. § 97; å beskytte forutsigbarhet og muligheten for innrettelse med hensyn til at de handlinger og disposisjoner man gjør, enten vil eller ikke vil ha de rettsvirkninger som følger av rettstilstanden til enhver tid. For å parafrasere flertallet i strukturkvotedommen; når det er

\footnotetext{
191 Ibid. avsnitt 153.

192 Ibid. avsnitt 153 (førstvoterende, dommer Utgård): «Eg kan vanskeleg sjå det annleis enn at det var hendingar og disposisjonar som fann stad i tidlegare år, som her vart gjenstand for meir omfattande skattlegging på grunn av overgangsreglane.»

${ }^{193}$ Avsnitt 195 (annenvoterende, dommer Matningsdal): «Da denne saken gjelder en uoppgjort, pådratt skatteplikt, avviker den fra situasjonen i Rt-2006-293 ved at det - i likhet med hva som var situasjonen i Rt1996-1415 - ikke «knyttes nye byrder til tidligere handlinger, men at lovendringen for fremtiden svekker rettslige posisjoner», jf. dommen side 1424.» 194 Ibid. avsnitt 153, som sitert over note 175.

195 Ibid., avsnitt 164: «Etter mitt syn hadde reiarlaga ei rettkomen forventing om at skattespørsmålet var avgjort for tida fram til det kom nye reglar, og at nye reglar på vanleg måte skulle gjelde framover» (min uthevning).
} 
tale om disposisjoner som var gjort ut fra datidens lov kan de ikke gjøres om igjen, det foreligger ingen mulighet for alternativ disponering for å møte den nye reguleringen. ${ }^{196}$ । prinsippet burde dette gjelde uten hensyn til om det er tale om å innskrenke en rettighet eller pålegge nye byrder. I begge tilfeller er jo de aktuelle rettsvirkningene både fremtidige og tyngende - skatten skal betales, rettigheten blir innskrenket.

Denne tilnærmingen er ikke i samsvar med flertallets synspunkter i strukturkvotedommen. Førstvoterende fremholdt uttrykkelig at det ved inngrep i rettigheter "gjennomgående i større eller mindre grad vil være mulig å innrette seg» og at «[b]ehovet for å kunne regulere pågående virksomhet er også gjennomgående større enn behovet for å gripe inn overfor avsluttet aktivitet.» ${ }^{197}$ Uttalelsene er likevel ikke entydige med hensyn til hvor sterkt dette ga en normativ føring også i situasjoner der et rettighetsinngrep har fellestrekk med egentlig tilbakevirkning, med andre ord der det foreligger konkret og tilsiktet innrettelse. For det første var førstvoterende klar på at «[s]like forhold vil kunne få betydning ved selve anvendelsen av normen». ${ }^{198}$ Og han fremholdt at normen fra Borthen-dommen måtte forstås slik at det var tale om "en relativ norm, som er fleksibel og skjønnsmessig» ${ }^{199}$ og som forutsetter en "konkret forholdsmessighetsvurdering». ${ }^{200}$ En underliggende premiss for flertallet synes i det hele tatt å ha vært at selve inngrepet i saken ikke var særlig alvorlig eller omfattende. ${ }^{201}$ Når rederiet fikk beholde strukturkvoten i 25 år ville de verdiene det hadde "gitt avkall på i forbindelse med struktureringen» være dekket inn med god margin. ${ }^{202}$ Innrettelseshensynet veide dermed ikke like tungt. Det er slett ikke opplagt at flertallet ville ha anvendt samme utgangspunkt hvis strukturkvoten hadde blitt opphevet med umiddelbar virkning eller etter mye kortere tid, og inngrepet dermed hadde hatt et klarere avståelseselement.

Den nyere Carl I Hagen-dommen gir støtte for en slik åpnere tilnærming der graden av tilbakevirkning eller «tilbakevirkningselementet» danner et utgangspunkt for den nærmere avveiningen. Etter gjennomgang av tidligere rettspraksis, herunder strukturkvotedommen, uttalte en enstemmig $\mathrm{H} \varnothing$ yesterett i avdeling om grunnlovsnormen:

«[K]jernespørsmålet er hvor sterkt tilbakevirkningselementet er. Hvis loven direkte knytter tyngende rettsvirkninger til tidligere hendelser, er loven som hovedregel grunnlovsstridig. Gir loven derimot bare regler om hvordan en allerede etablert posisjon skal utøves, er hovedregelen den motsatte. (...) Det er en glidende overgang mellom disse ytterpunktene. I

\footnotetext{
${ }^{196}$ Rt-2013-1345 avsnitt 95-97 (nummerering av avsnitt er utelatt): «Etter min mening er det gode grunner til å oppstille ulike normer for grunnlovsvernet for egentlig og uegentlig tilbakevirkning, slik det er gjort i rettspraksis. I utgangspunktet er det en prinsipiell forskjell mellom disse situasjonene: For å ta eksempelet fra rederiskattedommen - inntektsdisposisjonene i de angjeldende inntektsårene var gjort ut fra datidens lov og kunne ikke gjøres om igjen. Ved at loven direkte fikk virkning bakover i tid, slik jeg tolker flertallet, forelå det ingen mulighet for alternativ disponering for å møte den nye reguleringen.»

197 Ibid.

198 Ibid. avsnitt 98.

199 Ibid. avsnitt 101.

200 Ibid. avsnitt 99.

201 Ibid. avsnitt 122.

202 Ibid. avsnitt 108.
} 
rederiskattedommen omtales dette som «overgangsformer», mens det $\mathrm{i}$ strukturkvotedommen fremheves at «Borthen-normen» er relativ, fleksibel og skjønnsmessig. ${ }^{203}$

Med denne forståelsen av normen er man i realiteten kommet et godt stykke bort fra «klart urimelig eller urettferdig»-normen. Tilnærmingen innebærer en glidning bort fra et klart normativt førende utgangspunkt mot et fokus på den underliggende avveiningsnormen, som «uavhengig av normvalg» krever en vurdering av «hvilke rettigheter eller posisjoner inngrepet gjelder, hvilket grunnlag den enkelte eller en gruppe har for sine forventninger, om inngrepet er plutselig og betydelig, og om fordelingen av byrdene rammer den enkelte eller en gruppe særlig hardt.» ${ }^{204}$

Antagelig ser vi her reflektert noen av de samme betraktninger som har gjort at EMD ved anvendelsen av EMK P1-1 ofte unngår å kategorisere inngrepet, og i stedet anvender prinsippregelen direkte. Særlig ved omfattende rettighetsinngrep, som griper inn i sterke og beskyttelsesverdige forventninger, blir det lite igjen av utgangspunktet om at regulering må tåles. Skrittet er i det hele tatt ikke langt fra dette til å si at Borthen-dommens «klart urimelig eller urettferdig»-norm ikke gjelder ved omfattende rettighetsinngrep. Sagt på en annen måte: kravet til «sterke samfunnsmessige hensyn» blir langt på vei den naturlig implikasjon av at vi går inn i avveiningen etter å ha konstatert at inngrepet gjelder en særlig beskyttelsesverdig rettighet, vedrører klare og berettigete forventninger, er «plutselig og betydelig» og «rammer den enkelte eller en gruppe særlig hardt».

Nedenfor skal vi også se nærmere på noen andre holdepunkter for et skjerpet forholdsmessighetskrav, særlig der det skjer en tilsidesettelse av berettigede forventninger eller særretter.

\section{Betydningen av at det gripes inn i en berettiget forventning eller særrett}

\subsection{Innledning}

Konseptet berettigede forventninger har som allerede nevnt fått en sentral rolle $\mathrm{i}$ fortolkningen av eiendomsvernet i EMK P1-1. ${ }^{205}$ Slik det er blitt fortolket av menneskerettighetsdomstolen opptrer konseptet primært i to funksjoner. ${ }^{206}$ Man kan ha en berettiget forventning om utnyttelsen av eksisterende eiendom, for eksempel der man har fått en bestemt tillatelse eller konsesjon. ${ }^{207}$ Men også en berettiget forventning om å oppnå en bestemt eiendomsposisjon kan være beskyttet. Forutsetningen synes i så fall å være at

\footnotetext{
203 HR-2016-389-A avsnitt 76.

204 Ibid. avsnitt 77.

205 Solheim (2010) s. 283 flg.; og generelt Sigron (2014).

206 Solheim (2010) s. 288.

207 HR-2018-1258-A; Werra Naturstein Gmbh \& co KG, v. Germany, No. 32377/12 (2017); Vékony v. Hungary

No. 65681/13 (2015); Centro Europa 7 s.r.l. and di Stefano v. Italy, No. 38433/09 (2012); Pine Valley Development Ltd and others v Ireland, No. 12742/87 (1991); Fredin v. Sweden, No. 12033/86 (1991); Tre Traktörer AB v. Sweden, No. 10873/84 (1989).
} 
den berettigede forventning er i form av eller knyttet til et $k r a v,{ }^{208}$ som må være tilstrekkelig klart og definert, og ha slik forankring i en "rettsakt» under nasjonal rett, at det gis rimelig grunn til å bygge på den. ${ }^{209}$

Ethvert inngrep i en berettiget forventning vil imidlertid ikke være konvensjonsstridig - også her gjelder utgangspunktet om at bestående rettigheter kan reguleres. For at det skal foreligge et konvensjonsstridig inngrep gjelder som ellers hovedvilkåret om at inngrepet må være uforholdsmessig. ${ }^{210}$ Der en berettiget forventning helt eller i det vesentlige ignoreres eller tilsidesettes gjennom en senere myndighetshandling synes likevel domstolens utgangspunkt langt på vei å være at det foreligger en eiendomskrenkelse som aktualiserer et skjerpet forholdsmessighetskrav. Selv om domstolen ofte ikke anvender avståelsesregelen direkte på disse situasjonene vil tilsidesettelsen av en berettiget forventning ofte anses å medføre et element av avståelse. ${ }^{211}$ Som formulert av Solheim kan man da se det slik at konseptet berettigede forventninger dras inn i selve forholdsmessighetsvurderingen. ${ }^{212}$

I det følgende skal vi se nærmere på hvordan et lignende begrep om berettigede forventninger, uttrykkelig eller implisitt, også har spilt og spiller en viktig rolle ved fortolkningen av Grl. §§ 97 og 105. Først ser jeg på betydningen av dette under Grl. § 97 (pkt. 4.2). Deretter ser jeg nærmere på betydningen av innrettelse og opparbeidet bruk for forholdet mellom avståelse og rådighetsinnskrenkning under Grl. § 105 (pkt. 4.3). Endelig skal vi se nærmere på betydningen av hvor vesentlig eller omfattende inngrepet er (pkt. 4.4)

\subsection{Berettigede forventninger og særretter under Grl. § 97}

i. Betydningen av at det foreligger eller ikke foreligger en berettiget forventning Både Rt-2006-293 (Arves trafikkskole) og Rt-2010-143 (rederiskatt) kan ses under synsvinkelen etterfølgende annullering av konkret og velbegrunnet forutsatte virkninger av en fortidig disposisjon. ${ }^{213}$ Særlig sistnevnte sak gir det god mening å se som at det i form av en berettiget forventning var etablert en rett til skattefrihet under gitte betingelser, som så ble annullert gjennom en etterfølgende lovendring. ${ }^{214}$ Men også i Arves trafikkskole fremhevet førstvoterende at saks $\varnothing$ keren var blitt «fratatt en $\varnothing$ konomisk rettighet.» ${ }^{215}$ Siden

\footnotetext{
208 Jf særlig storkammerdommen i Kopecky v Slovakia, No. 44912/98 (2001), avsnitt 35: “Possessions” can be either "existing possessions" or assets, including claims, in respect of which the applicant can argue that he or she has at least a "legitimate expectation" of obtaining effective enjoyment of a property right." Se også for eksempel Pressos Compania Naviera S.A. and others v Belgium, No. 17849/91 (1995); Gratzinger and Gratzingerova v The Czech Republic, No. 39794/98 (2002); Jantner v Slovakia, No. 39050/97 (2003).

${ }^{209}$ Kopecky v Slovakia, No. 44912/98 (2001), avsnitt 45-52.

210 HR-2018-1258-A.

211 Se ovenfor pkt. 3.3.iii.

212 Solheim (2010) s. 303.

${ }^{213}$ Riktignok bør det nevnes at flertallet i strukturkvotedommen ikke forstod dommene på denne måten, men her er det et spørsmål hvor mye vekt som bør legges på de prinsipielle uttalelsene i dommen, jf. over pkt. 3.4. ${ }^{214}$ Rt-2010-143 avsnitt 164: «Etter mitt syn hadde reiarlaga ei rettkomen forventing om at skattespørsmålet var avgjort for tida fram til det kom nye reglar, og at nye reglar på vanleg måte skulle gjelde framover» (min uthevning).

${ }^{215}$ Rt-2006-293 avsnitt 70
} 
det ikke var etablert noen egentlig, definert rettighet, må synspunktet ha vært at trafikkskolen hadde en rettighet, i form av en berettiget forventning om skattefritak, når det ble disponert i tillit til det eksisterende regelverket. ${ }^{216}$

Eldre høyesterettspraksis om beskyttelse av rettsposisjoner etablert på grunnlag av offentlige tillatelser og konsesjoner, har gjennomgående ansett det avgjørende om reguleringen var i strid med forutgående konkrete og klare tilsagn fra myndighetene som den private har hatt grunn til å innrette seg etter. Samtidig har dette vært kombinert med et utgangspunkt om at det skal ganske mye til for å fastslå at det foreligger noe slikt tilsagn. I Vauvert-dommen var spørsmålet om en rett til å selge brennevin basert på et såkalt "handelsborgerskapsbrev» var beskyttet mot den nye alkohollovgivningen som forb $\varnothing \mathrm{d}$ slikt salg. Høyesterett kom til at handelsbrevet ikke kunne forstås slik at adgangen til å selge brennevin kunne «ansees tilsagt som en rettighet der skal bestaa uavhængig av senere lovgivning. " ${ }^{217}$ Begrunnelsen er bemerkelsesverdig moderne i synspunktet på om det var grunnlag for en berettiget forventning som bandt lovgivningsmakten:

Man maa efter min mening hvor det gjælder offentlige retsforhold som nærværende, hvis nærmere indhold er av væsentlig betydning for spørsmaalet om statens adgang til at reformere en vigtig del av næringslovgivningen efter almenvellets og samfundsutviklingens behov, være meget forsigtig med at bedømme en holdning fra det offentliges side som den det her er tale om paa en saadan maate at den binder lovgivningsmagtens fri hænder. ${ }^{218}$

Også de to senere sakene om vinmonopolets konsesjon fra 1929 og 1931 bygger på tilsvarende betraktninger. Spørsmålet var om konsesjonen forhindret at et garantert aksjonærutbytte ble ilagt kommuneskatt. ${ }^{219}$ I den første saken kom Høyesterett til at i og for seg begrunnede forventninger, som var dannet gjennom uttalelser fra ulike myndigheter $\mathrm{i}$ forbindelse med tilståelsen av konsesjonen og opprettelsen av selskapet, kunne gi «en sterk moralsk grunn til bibehold av den paa forhandlingstiden gjeldende lovregel. $»^{220}$ Men flertallet kom likevel til at dette ikke var tilstrekkelig til at myndighetene kunne anses å ha forpliktet seg. ${ }^{221}$ Det hadde formodningen mot seg at staten skulle ha bundet sin

\footnotetext{
${ }^{216}$ Det prinsipielle synspunktet her er også forenlig med mindretallets posisjon, der annenvoterende dommer Rieber-Mohns argumenter for at avgiftsendringen ikke utgjorde grunnlovsstridig tilbakevirkning var at trafikkskolen ikke hadde innrettet sine disposisjoner på grunn av noen forventning om avgiftsfrihet, at trafikkskolen ikke hadde noen sterke og konkret funderte forventninger i så måte, og at inngrepet ikke rammet særlig hardt, jf. særlig dommen avsnitt 96 og 98 flg.

${ }^{217}$ Rt-1922-624 på s. 624-625. Dommen innebærer slik sett en nokså klar kursendring fra Høyesteretts tidligere linje. I en sak kun få år tidligere fant for eksempel Høyesterett at ny skattlegging som «vesentlig forringet» verdien av salgbare apotekerprivilegier ble ansett grunnlovsstridig, jf. Rt-1917-392.

218 Rt-1922-624 s. 625.

${ }^{219}$ Rt-1929-529 og Rt-1931-1138. Selv om grunnlovens § 97 ikke ble uttrykkelig trukket frem i premissene var spørsmålet i saken om konsesjonen ga aksjonærene en rett som var beskyttet mot endringene i skattelovgivningen, slik at hjemmelen for å sette loven til side vel forutsetningsvis måtte ha vært Grl. § 97 enten som skranke eller tolkningsmoment.

${ }^{220}$ Rt-1929-529 på s. 533.

${ }^{221}$ Dissens 5-2. Mindretallet anså staten forpliktet utfra den (i dag vel nokså foreldete) betraktning at når staten hadde garantert et bestemt utbytte måtte det også medføre at det offentlige ikke kunne inndra noen del av dette utbyttet som skatt.
} 
beskatningsmyndighet på denne måten, ${ }^{222}$ og det forelå ikke «noget uttrykkelig tilsagn om skattefrihet i de trufne avtaler.» ${ }^{223}$ At det nok kunne være en viss tvil om rettstilstanden medførte imidlertid at spørsmålet kort tid etter på nytt kom opp for Høyesterett, som nå tok stilling til det i plenum. Med et minst mulig flertall (11-10) opprettholdt Høyesterett synspunktet om at selv om partene nok kunne ha hatt visse forutsetninger i denne retning, var det ikke gitt noe uttrykkelig tilsagn om skattefrihet, og det kunne heller ikke formodes at staten mente å binde seg på denne måten. ${ }^{224}$ Også dette kan vi se som utslag av en konkret tolkning av om aksjonærene hadde fått en berettiget forventning, men med utgangspunkt i en formodning mot statlig bundethet. ${ }^{225}$

Både Vauvert- og Vinmonopol-dommene gir eksempler på at berettigelsen av forventninger, eller snarere den manglende sådanne, ofte kan tjene som begrunnelse for at det ikke foreligger et grunnlovsstridig rettighetsinngrep. Der en rettighet ikke er uttrykkelig tilsagt eller klart forutsatt å være immun mot senere lovgivning, er formodningen at regulering må tåles. ${ }^{226}$ Vi har imidlertid eksempler i rettspraksis på at senere lovgivning som griper inn i klart definerte rettigheter under et etablert konsesjonsforhold, i realiteten har blitt satt til side. I Phillips-dommen var spørsmålet om en forskrift som endret betalingsterminene for produksjonsavgift (royalty) ved utvinning av petroleum, fra halvårlige til kvartalsvise betalinger, også gjaldt eldre utvinningstillatelser. ${ }^{227}$ Den nye ordningen var $\emptyset$ konomisk mindre gunstig for oljeselskapene, fordi de gikk glipp av rente- og likviditetsfordelen ved å betale sjeldnere. Oljeselskapene hevdet at vilkårene i de gamle utvinningstillatelsene knyttet til beregning og betaling av produksjonsavgift, måtte ses som et forhandlet og avtalt vederlag for retten til å utvinne petroleum. $\mathrm{H} \varnothing$ yesterett tok ikke uttrykkelig stilling til om staten var avskåret fra å gripe inn under Grl. § 97, men kom til at den nye forskriften i lys av rettighetsvernet måtte tolkes innskrenkende til ikke å gripe inn i de eldre utvinningstillatelsene. ${ }^{228}$ Med andre ord var det ikke Grl. § 97 som skranke, men som tolkningsmoment for etterfølgende lovgivning, som her ble ansett avgjørende. ${ }^{229}$

\footnotetext{
222 Ibid. s. 533.

223 Ibid. s. 534.

224 Ibid. s. 1140, representant for flertallet dommer Altens votum: «Under forhandlingene har man, saavidt skjønnes, fra begge sider regnet med den gjeldende lovgivning likesom med pengemarkedets stilling og andre faktiske forhold. Sannsynligvis har man ogsaa tenkt sig at kommunal beskatning av aktiene ikke vilde bli innført. Men derfra er der et langt skritt til at anse Staten bundet til ikke at forandre beskatningen.»

${ }^{225}$ Mindretallet mente derimot at det ikke gjaldt noen slik formodning. Se særlig dommer Lies votum, med særmerknader fra dommerne Schjelderup, Hanssen og Bang.

${ }^{226}$ I petroleumsvirksomheten har det for eksempel blitt antatt at ny lovgivning, herunder om skjerpet beskatning for fremtiden, som utgangspunkt kan anvendes på eldre utvinningstillatelser. Når det gjaldt adgangen til å øke petroleumsskatten mente lovavdelingen at staten “i utgangspunktet [må] stå fritt overfor selskapene til å gjøre bruk av sin myndighet til generell skattlegging, så langt det ikke gjøres inngrep I spesielle avtalevilkår tatt inn i den enkelte utvinningstillatelse," jf. Ot. Prp. nr. 26 (1974-1975) på s. 43. Se nærmere Bugge (1999) s. 84 flg. med videre henvisninger.

${ }^{227}$ Rt-1985-1355.

228 Ibid. s. 1378-1379.

${ }^{229}$ Se om denne distinksjonen for eksempel Benedikte Moltumyr Høgberg, «Tilbakevirkningsforbudet som rettskildeprinsipp» i Alf Petter Høgberg og Jørn Øyrehagen Sunde (red.), Juridisk metode og tenkemåte, Universitetsforlaget 2019, s. 562-567.
} 
Førstvoterende forutsatte likevel helt generelt at omstendighetene rundt utvinningstillatelsen medførte at staten ikke stod fritt til å endre de tilsagte vilkårene. ${ }^{230}$ Det ble ikke tatt klart stilling til hvilke bindinger utvinningstillatelsen medførte for staten, men førstvoterende uttalte om dette at «[v]ed vurderingen av adgangen til endringer av vilkårene på dette punkt, kan det (...) være et moment om endringen har noen vesentlig betydning. ${ }^{231}$ | mer moderne terminologi kan vi si at det dermed forutsetningsvis ble lagt til grunn at det var etablert en distinkt rettsposisjon - en berettiget forventning - som i utgangspunktet var beskyttet etter Grl. § 97 mot «vesentlige» inngrep. Å utlede fra dette at Høyesterett anså pålegget om hyppigere betaling av produksjonsavgift som brudd på en berettiget forventning, som aktualiserte det vi i dag ville kalle "sterke samfunnsmessige hensyn»-normen under Grl. § 97, blir kanskje å lese for mye inn i dommen. De motstående vurderingstemaene «klart urimelig eller urettferdig» og "sterke samfunnsmessige hensyn» hadde på dette tidspunktet ennå ikke utkrystallisert seg i rettspraksis. Men utfallet er ganske klart forenlig med et slikt synspunkt. Og resonnementet i dommen er i alle fall lite forenlig med synspunktet i Borthen-dommen vel 10 år senere om at det var etablert en beskyttet rettsposisjon under Grl. §97, som lovgiver likevel som utgangspunkt stod fritt til å regulere. Slik sett gir det mening å se dommen som utslag av den samme tilnærmingen som senere har ført til introduksjonen av et skjerpet forholdsmessighetskrav i form av kravet til sterke samfunnsmessige hensyn.

\section{ii. Inngrep i «særretter»}

Gullklausul-dommen, som førstvoterende i Arves trafikkskole tok utgangspunkt i ved formuleringen av «sterke samfunnsmessige hensyn»-normen, kan både ses under synsvinkelen regulering av en overordnet rettsposisjon og tilsidesettelse av en definert særrett. Lovgivningen som suspenderte gullklausulene innebar en regulering av den fremtidige utnyttelsen av etablerte rettsposisjoner begrunnet $\mathrm{i}$ «samfunnets vitale interesser. ${ }^{232}$ Når gullklausulene ble suspendert, eller i praksis annullert, bet $\varnothing \mathrm{d}$ det imidlertid også at kreditorene ble fratatt en særskilt rettighet - retten til å få tilbakebetalt lånet i henhold til gullverdien. Når flertallet i Arves trafikkskole fortolket gullklausuldommen som et tidlig utslag av en «sterke samfunnsmessige hensyn»-norm må begrunnelsen ha vært at faste og klart definerte særretter ble tilsidesatt.

At det i tilknytning til en overordnet rettsposisjon kan utkrystalliseres særrettigheter som nyter en form for avståelsesvern er forutsatt i plenumsdommen i Rt-1990-284 (Selsbakkdommen). Spørsmålet i saken var om en avtalt innløsningsrett til markedspris for bortfesterne i visse tomtefesteavtaler, kunne gjøres gjeldende i strid med etterfølgende lovgivning som gjorde slike innløsningsretter ugyldige. Høyesteretts flertall kom til at loven ikke kunne gjøres gjeldende på innløsningskrav som allerede var fremsatt da loven ble gitt. Latente, ennå ikke fremsatte innløsningskrav, var derimot ikke omfattet av

\footnotetext{
230 Rt-1985-1355 på s. $1373-1374$.

231 Ibid. s. 1374.

232 Rt-1962-369 på s. 385. Alternativet til regulering var også svært dramatisk, synspunktet synes å ha vært at man risikerte noe nær finansiell kollaps ved å ikke gripe inn overfor gullklausulene.
} 
grunnlovsvernet. ${ }^{233}$ Også i sistnevnte situasjon ble det lagt til grunn at loven «griper sterkt inn i sentrale deler av lovlig inngått festeavtale hvor retten til å kreve innløsning til markedspris kan ha vært avgjørende for at bortfesteren valgte å feste bort sin eiendom ${ }^{234}$ Den avgjørende betraktningen for å anse at de fremsatte innløsningskravene var beskyttet synes å ha vært at det fra innløsningstidspunktet forelå et formalisert og aktualisert krav. ${ }^{235}$

En mulig betraktning kunne vært at innløsningskravene, men ikke andre latente og fremtidige krav under kontrakten, hadde utkrystallisert seg på en måte som gjorde at det forelå «eiendom» under Grl. § 105. De fremsatte innløsningskravene var aktualisert på en måte som ga dem en avklart og endelig karakter, og dermed en form for tingliggjøring, som andre, latente krav med grunnlag i kontrakten manglet. Resonnementet i dommen var likevel ikke uttrykkelig knyttet opp mot Grl. § 105. Det styrende synspunktet synes derimot å ha vært at det ville være grunnlovsstridig tilbakevirkning å gi loven virkning på allerede manifesterte rettsvirkninger av en foretatt disposisjon ville. Men man kunne nok like gjerne formulert dette som at det hadde utkrystallisert seg en særrett hvor det å gi loven virkning ville innebære et ekspropriasjonselement.

Selsbakk-dommen målbærer tilsynelatende en ganske restriktiv holdning til når det foreligger en tilstrekkelig fast og utkrystallisert særrett. Skillelinjen som oppstilles i dommen er ganske formell. Også bortfestere som ikke hadde fremsatt noe innløsningskrav hadde en klar kontraktsforankret rett, som utgjorde en sentral og viktig forutsetning ved kontraktsinngåelsen. Hensikten var å sikre dem retten til en fremtidig markedsverdistigning dersom prisreguleringen av fast eiendom, som holdt prisen på slike tomter kunstig nede, skulle falle bort. ${ }^{236}$ I dag kunne man nok stilt spørsmålet om ikke også den kontraktsfestede retten til innløsning i seg selv utgjorde en berettiget forventning med krav på vern. ${ }^{237}$

\footnotetext{
233 Dommen er avsagt under dissens 9-8, men dissensen gjaldt ikke det prinsipielle grunnlovsspørsmålet. Mindretallet kom til at den kontraktsfestede innløsningsadgangen var i strid med avtl. § 36, også med virkning for de fremsatte innløsningskravene. Det oppstod dermed ikke noe spørsmål om grunnlovsstridig tilbakevirkning ved at loven ble gitt virkning.

${ }^{234}$ Rt-1990-284 på s. 295.

235 Ibid. s. 294-295.

236 Ibid. s. 295.

237 Jf. tilnærmingen i Lindheim-dommen, Lindheim v. Norway, App 13221/08 og 2139/10 (2012), avsnitt 133: «The Court accepts however that the applicants could entertain a legitimate expectation that the relevant lease contracts would expire as agreed according to their terms, independently of the intervening discussions on and adoption of legislative measures.» En sentral betraktning i dommen synes likevel å ha vært at den kontraktsfestede innløsningsretten stod i en spenning mot legitime interesser hos festerne, som mindretallet mente allerede var beskyttet under avtl. $\S 36$. Selv om flertallet var uenig i dette, ble det generelt fremholdt at man i denne typen avtaler må forvente at (s. 295): «lovgiverens syn på hva som vil være rettferdig eller akseptabelt kan endre seg, og at utviklingen også ellers får et annet forløp enn forutsatt.»
} 
iii. Nærmere om grunnlaget for en avståelsesregel ved tilsidesettelse av berettigede forventninger og særretter under Grl. § 97

I tillegg til flertallet i strukturkvotedommen som er diskutert over og som vi skal komme tilbake til nedenfor, ${ }^{238}$ går særlig plenumsdommen i Rt. 2007 s. 1281 ( $\varnothing$ vre Ullern terrasse) langt i å avvise at det gjelder noen egen «avståelsesregel» under Grl. § 97. Spørsmålet i saken var om retten etter tomtefesteloven til å kreve festet forlenget på samme vilkår etter festekontraktens utløp var i strid med bortfesters rettigheter etter Grunnloven.

Forlengelsesadgangen medførte at bortfester i realiteten ble fratatt retten til å nyte godt av verdiøkning på eiendommen i tiden etter at festekontrakten ble inngått. Den utgjorde altså et klart innhugg i bortfesters eiendomsrett. Høyesterett kom da også til at inngrepet måtte ses som en avståelse av eiendomsrådighet, og ikke bare en rådighetsinnskrenkning. ${ }^{239}$ Men en samlet $\mathrm{H} \varnothing$ yesterett (riktignok bare syv dommere på grunn av at mange var inhabile) kom likevel til at forholdet i saken ikke falt inn under $\S 105$, men derimot måtte vurderes under $\S$ 97 fordi dette var i samsvar med «vår rettstradisjon». 240

Mot $\mathrm{H} \varnothing$ yesteretts resonnement, og til st $\varnothing t t e$ for rettens konklusjon, kunne man nok hevde at synspunktet om at det her var tale om en avståelse og ikke en rådighetsinnskrenkning fremstår vel bastant. Overfor bortfesters eiendomsrett som sådan utgjorde tomtefestelovgivningen åpenbart en regulering og ikke en avståelse. Bortfester beholdt fortsatt sin formelle eiendomsrett, men hans fremtidige utnyttelse av eiendommen ble begrenset til å motta en fastsatt festeavgift. At festeavgiften ble låst til samme nivå uten mulighet til markedsjustering kunne man se som en form for prisregulering som det er lang praksis for å godta under både Grl. §§ 97 og 105. ${ }^{241}$ Det spesielle i saken var at man grep inn i den berettigede forventning som lå i at festekontrakten som $\varnothing$ konomisk realitet, tidligere hadde en begrenset varighet. Her lå det klart nok et avståelseselement eller en verdioverføring fra bortfester til fester sammenlignet med den opprinnelige festekontrakten. Høyesterett anerkjente også dette, men fant altså at den nærmere vurderingen hørte hjemme under Grl. § 97 og ikke § 105.

Resonnementet forutsetter slik sett at det ikke gjelder noen egen «avståelsesnorm» under Grl. § 97. Samtidig vet vi at Norge ble dømt i EMD for overtredelse av P1-1 nettopp på dette punktet i Lindheim-dommen, blant annet med henvisning til prinsippet om berettigede

\footnotetext{
238 Jf. ovenfor pkt. 3.4. Og i resultat er også dommen som vi skal se langt på vei forenlig med en slik avståelsesregel, jf. nedenfor pkt. 4.4 .

${ }^{239}$ Rt-2007-1281, avsnitt 89: «Retten til forlengelse i § 33 atskiller seg klart fra en regulering av eiendomsrådigheten. Ved $\S 33$ er festeren gitt en rett til å feste tomten i en lengre periode enn avtalen gir adgang til. Det er altså tale om overføring av rettigheter til eiendommen ut over den avtalte perioden - noe som isolert sett kunne tale for at forholdet direkte reguleres av $\S 105 . »$

240 Ibid. avsnitt 90: «Det er en regulering - med tilbakevirkning - direkte knyttet opp til avtalen, eller rettere sagt til begrensningene i den, som lovbestemmelsen gir. En slik etterfølgende regulering, knyttet opp til et kontraktsforhold mellom partene, har i vår rettstradisjon vært vurdert ut fra Grunnloven § 97, og ikke ut fra § 105. Det gjelder også om reguleringen har medført en overføring av rettigheter og plikter partene imellom. Synsvinkelen må også kunne anvendes i et tilfelle som det foreliggende selv om inngrepet i avtalen innebærer en overføring av rådighet.»

${ }^{241}$ Se Rt-1924-949 og Rt-1929-771, og jf. også Rt-1919-742 og Rt-1921-721 om husleieregulering.
} 
forventninger. ${ }^{242}$ I ettertid er det lett å se $\varnothing$ vre Ullern-dommen som et utslag av at EMK P1-1 på visse områder gir et mer omfattende vern enn det som følger av Grunnloven. Men dette kan være en forhastet slutning. Også grunnlovstolkningen i dommen er diskutabel og fortjener et kritisk søkelys. ${ }^{243}$ At rettens tolkning av P1-1 senere ble tilbakevist av EMD svekker vekten av dommen med hensyn til drøftelsen av Grl. § 97. Det problematiske i rettens resonnement er særlig forutsetningen om at «reguleringsvernet» etter § 97 ga en svakere beskyttelse enn «avståelsesvernet» etter $\S 105$. Realiteten i saken slik også Høyesterett så det var jo at det forelå en regulering med et klart avståelseselement. Man kan dermed se det slik at det som ledet retten til et utfall som viste seg å være strid med P11 , nettopp var synspunktet om at Grl. § 97 kunne anvendes uten at den nødvendige indre sammenhengen med prinsippet i Grl. § 105 ble anerkjent.

Drøftelsen over viser at det, til tross for en viss motstand og inkonsistens i Høyesteretts praksis, er ganske sterke holdepunkter for at inngrep som rokker ved konkret og velbegrunnet forutsatte virkninger av fortidige disposisjoner og handlinger, aktualiserer et skjerpet forholdsmessighetskrav. At det foreligger en særrett som i seg selv utgjør "eiendom» etter Grl. § 105, vil normalt tilsi at det foreligger en rettsposisjon som normalt heller ikke kan tilsidesettes eller utslukkes gjennom etterfølgende regulering, i alle fall uten at det er påkrevet av sterke samfunnsmessige hensyn. Men som vi har sett over er det mye som taler for at kretsen av beskyttede rettigheter under Grl. § 97 og EMK P1-1 også rekker noe lenger enn under $\S 105$. Analogien fra eiendomsvernet under EMK kan tilsi at det også her må gjelde en form for avståelsesvern, ikke i form av en absolutt erstatningsplikt, men derimot et skjerpet forholdsmessighetskrav. For eksempel er det tvilsomt om alle trygde- og pensjonsytelser utgjør eiendom etter Grl. § 105. Men det er likevel sterke hensyn som tilsier at inngrep som går langt i å tilsidesette eller uthule slike rettigheter aktualiserer et strengere krav til forholdsmessighet enn det som følger av «klart urimelig eller urettferdig»-normen. Det er ikke gitt at hverken utgangspunktet eller utfallet i rekken av dommer som har behandlet pensjonsrettigheter under Grl. § 97 hadde vært det samme om situasjonen hadde vært at lovgivningen helt eller i det alt vesentlige fratok pensjonistene deres fremtidige rett til pensjon. ${ }^{244}$ Grunnlovsbeskyttelse i denne sammenhengen uten et klart utgangspunkt om avståelsesvern vil i realiteten ikke være mye verdt.

4.3. Forholdet mellom delvis avståelse og rådighetsinnskrenkning under Grl. § 105 At det foreligger en berettiget forventning eller særrett kan også ha betydning for skillelinjen mellom delvis avståelse og rådighetsinnskrenkninger under Grl. § 105. Den enstemmige plenumsdommen i bankdemokratiseringssaken er illustrerende. Spørsmålet i saken var om lovgivning som medførte at aksjonærene mistet den $\varnothing$ verste bestemmelsesretten over forretningsbankenes virksomhet, var i strid med Grl. § 105. Aksjonærene kunne etter loven

\footnotetext{
242 Jf. over pkt. 3.3.iii.

${ }^{243}$ Se også Frode Innjord, «Forholdet mellom Grunnloven § 97 og § 105» Tidsskrift for eiendomsrett, 2008 Nr. 1, s. 11-27.

244 Jf. Rt-1996-1415, Rt-1996-1440 og HR-2016-389-A. Dommen i Rt-2006-262 harmonerer ikke like godt med et slikt synspunkt. En underliggende betraktning her synes imidlertid å ha vært at det ikke forelå noen særlig sterk, berettiget forventning om den aktuelle pensjonsytelsen. Et spørsmål er dermed om dommen like gjerne kunne vært begrunnet med at den aktuelle pensjonsrettigheten ikke var beskyttet under Grl. § 97.
} 
kreve at staten innløste aksjene etter omsetningsverdi, men spørsmålet var om det fulgte av Grl. § 105 at de i stedet kunne kreve en forholdsmessig andel av substansverdien i selskapet dersom denne var høyere. Høyesterett kom til at aksjens omsetningsverdi tilfredsstilte kravet til full erstatning, men tok også stilling til om reguleringen utgjorde et ekspropriasjonsartet inngrep som aktualiserte kravet om full erstatning etter $\S 105$. Retten kom her til at når aksjonærene ikke lenger hadde den «avgjørende bestemmelsesrett over forretningsbankenes drift som de tidligere har hatt» utgjorde dette et ekspropriasjonsartet inngrep, det vil si «et inngrep av slik betydning at det må utløse krav om erstatning som i utgangspunktet må svare til det $\varnothing$ konomiske tap aksjeeierne kan antas å være blitt påført ved nyordningen. ${ }^{245}$

For den enkelte aksjonær hadde omleggingen til at den $\varnothing$ verste myndighet i bankene ble ut $\varnothing v d$ av et politisk oppnevnt representantskap antagelig ikke veldig stor betydning, hverken økonomisk eller på noen annen måte. Aksjonærene beholdt alle økonomiske rettigheter, som rett til utbytte, salg mv. Medbestemmelsesretten som i utgangspunktet fulgte den enkelte aksje var i praksis nokså begrenset. Hver enkelt aksjonær hadde aldri hatt noen direkte tilgang til formuesmassen i selskapet, eller noen særlig innflytelse over virksomheten. Det var ingenting som tilsa at inngrepet rammet enkeltaksjonærer på en så omfattende måte at det kunne anses "sterkt urimelig eller urettferdig.» Synspunktet må dermed ha vært at lovgivningen angrep en essensiell del av eiendomsretten fordi den fratok aksjonærene bestemmelsesretten over selskapet. Altså forelå en ekspropriasjonsartet avståelse av en del av aksjonærenes eiendomsrett.

Bankdemokratiseringssaken illustrerer at synspunktet på eiendomsretten som en negativt definert rådighet, og altså kun en funksjon av lovgivningen til enhver tid, kan bli for unyansert. I denne saken kom $\mathrm{H} \varnothing$ yesterett til at reguleringen grep inn i kjernen av eiendomsretten på en måte som måtte likestilles med ekspropriasjon av en del av eiendomsretten. Men eiendomsrett kan også gi grunnlag for disposisjoner, handlinger og innrettelse som så og si fyller eiendomsretten med innhold og gir den et mer «positivt» preg. Gjennom etablert bruk, virksomhet og investeringer i tilknytning til eksisterende eiendom kan det utkrystalliseres mer definerte rettsposisjoner med et legitimt krav på beskyttelse.

I strandlovdommen la Høyesterett særlig vekt på at forbudet mot bygging i strandsonen ikke grep inn i etablert bruk. ${ }^{246}$ Senere har Høyesterett riktignok tilkjennegitt en nokså restriktiv linje også med hensyn til hvor langt eksisterende utnyttelse og virksomhet er vernet av Grl. § 105. I Rt-1978-442 (Lamyra) kom flertallet til at et fredningsvedtak som rammet den etablerte utnyttelsen av en sandforekomst måtte likestilles med ekspropriasjon. Dette synspunktet ble uttrykkelig fraveket av en samlet Høyesterett i plenumsdommen i Rt-198780 (Rønnåsmyra II). ${ }^{247}$ Ankepunktet mot Lamyra-dommen synes imidlertid primært å ha vært at flertallet der kom til at det forelå en ekspropriasjonsartet avståelse, uten hensyn til om

\footnotetext{
245 Rt-1979-572 på s. 586.

${ }^{246}$ Rt-1970-67 på s. 74: «Forbudet medfører ingen inngrep i den etablerte bruk eierne før forbudet måtte ha gjort av sin eiendom. Den kan fortsettes som $f \varnothing r$, og i den utstrekning det er foretatt arbeid eller andre investeringer for denne bruk, kan dette nyttiggjøres som $f ø r . »$

247 Jf. også Rt-1980-94 og Rt-1982-850, som førstvoterende viste til.
} 
inngrepet var vesentlig eller ikke. ${ }^{248}$ Men senere må det også anses fastslått at heller ikke

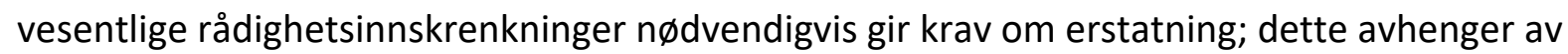
en mer omfattende vurdering hvor spørsmålet er om inngrepet har «en slik karakter at det ut fra en helhetsvurdering fremstår som sterkt urimelig om det skal tåles». ${ }^{249}$ Ingen av dommene som bygger på det sterke utgangspunktet om at rådighetsinnskrenkninger må tåles, gjelder imidlertid vesentlige inngrep i en etablert innrettelse eller bruk. ${ }^{250}$ I Rt-2005469 ble det vektlagt at eierne ikke hadde fått alle nødvendige tillatelser til den aktuelle utnyttelsen, og således, implisitt, ikke hadde en berettiget forventning. ${ }^{251}$

Enhver påbegynt eller planlagt bruk kan naturligvis ikke aktualisere noe utgangspunkt om vern. For å aktualisere dette må omstendighetene i det minste være slik at rettshaveren har en berettiget forventning om at en bestemt situasjon vil vedvare. Spørsmålet er imidlertid om slike omstendigheter aktualiserer noe eget og sterkere utgangspunkt om vern, eller kun gir momenter av betydning under «sterkt urimelig»-normen. Rt-2005-469 må kanskje anses å bygge på sistnevnte syn. Her avviste Høyesterett at etablert uttak av grus på en gårdseiendom hadde noe særlig vern, men dommen kan også leses slik at Høyesterett ikke anså den etablerte utnyttelsen særlig beskyttelsesverdig. ${ }^{252}$ Dommen i Rt-1998-1140 berører samme problemstilling, men gir heller ikke grunnlag for noen helt entydig slutning. Førstvoterende (som her utgjorde mindretallet) synes klart å forutsette at etablert bruk, herunder eksisterende bygninger, i noen sammenhenger aktualiserer et sterkere utgangspunkt om vern. ${ }^{253}$ Spørsmålet i saken var imidlertid om eierens forventninger om å

\footnotetext{
${ }^{248}$ Se Rt-1978-442 på s. 447 flg., Rt-1987-80 på s. 89, og se også Rt-1980-94 på s. 98 flg. (hvor det imidlertid også ble fremholdt at nydyrkingsforbudet ikke rammet noen konkret, planlagt bruk, jf. s. 99)

${ }^{249}$ Rt-2005-469 avsnitt 29, se også Rt-2004-1092 avsnitt 76 og Rt-1988-890 på s. 907.

250 I flere av dommene er dette også uttrykkelig vektlagt, se Rt-1993-321, særlig s. 326 flg., hvor det ble fremhevet at inngrepet i liten grad rammet grunneiernes eksisterende virksomhet, det var forventningen om fremtidig utbygging som ble rammet, og denne «byggesjansen» hadde tradisjonelt svakt vern. Jf. også Rt-1988890, førstvoterende dommer Bugge, på s. 897: «Det har videre vært antatt at det skal mere til få å tilkjenne erstatning når vernetiltaket hindrer nye former for utnyttelse av eiendommen enn når det gjelder inngrep i eksisterende bruk». Og jf. videre på s. 898: «Griper vernetiltaket derimot inn i eierens aktuelle drift av eiendommen, vil det lettere kunne bli tale om erstatning. Men også da må det kreves at rådighetsinngrepet, og dermed det $\varnothing$ konomiske tap, er vesentlig for eieren.» Førstvoterende var imidlertid i mindretall (3-2) med hensyn til utgangspunktet for en eventuell erstatningsplikt, der flertallet anført av dommer Skåre vek tilbake for helt generelt å oppstille en hovedregel om erstatningsplikt basert på (s. 898): «om den eiendom som omfattes av vernetiltaket, sett som helhet, fortsatt kan drives eller utnyttes som tidligere, med i det vesentlige samme utbytte som før vernetiltaket ble iverksatt.»

251 Jf. Rt-2005-469 avsnitt 47.

252 Ibid. avsnitt 49: «Som redegjort for er det ikke tilstrekkelig for erstatningsansvar at det er tale om et vesentlig inngrep. Det må ha en slik karakter at det ut fra en helhetsvurdering vil være sterkt urimelig om inngrepet skal tåles. Jeg finner ikke grunn til å gå inn på om karakteriseringen av tapet som vesentlig, bygger på uriktig rettsanvendelse. Etter en helhetsvurdering på grunnlag av de kriterier som er trukket opp av Høyesterett, gir inngrepet ikke under noen omstendighet rett til erstatning. Vernevedtaket tok sikte på å beskytte mot den type varig og irreversibelt inngrep i naturen som Larsens grusuttak innebar, og vedtaket forfølger et viktig samfunnsmessig mål.»

253 Dommen s. 1157-1158: «lkke i noen av disse avgjørelsene var det tale om regulerte byggetomter som tidligere hadde vært bebygd gjennom mange år. Tomtene i Hydalen lå i et seterdalføre og hadde aldri vært bebygd. For Småsetrans vedkommende måtte byggemulighetene i flere tiår ha fremstått som meget usikre. Forholdene langs Akerselva er helt annerledes. Det foreligger her en etablert tomtebruk og tomteverdi.
} 
kunne bygge på eiendommen i samsvar med tidligere utnyttelse i området var beskyttet. Det var altså ikke tale om å forby en allerede etablert utnyttelse av eiendommen. ${ }^{254}$ Flertallet anført av andrevoterende dommer Aarbakke bygget i tråd med dette på utgangspunktet etablert gjennom tidligere praksis, om at «en utbyggingsforventning ikke i seg selv har erstatningsrettslig vern. ${ }^{255}$

Selv om rettspraksis dermed ikke gir grunnlag for helt klare slutninger kan det vel ikke være særlig tvil om at inngrep i eksisterende bruk og foretatte investeringer i noen sammenhenger vil være så inngripende at utgangspunktet må være at det foreligger et ekspropriasjonsartet inngrep som utløser erstatningsplikt. Eksempelvis ville en ny strandlov, som påbød fjerning av eksisterende bygninger nærmere enn en viss avstand fra sjøen, antagelig være i strid med ekspropriasjonsvernet. Helt klart ville dette måtte være for eiendommer der hele bygningsmassen ligger innenfor påbudssonen. Men det avgjørende er antagelig ikke i og for seg om lovgivningen har virkninger som kan likestilles med avståelse av hele eiendomsretten som sådan, og heller ikke om inngrepet overfor den enkelte har et slikt omfang at det fremstår "sterkt urimelig eller urettferdig». Også bryggeanlegget, strandboden eller båthuset som må rives, uten at det i vesentlig grad affiserer verdien av praktlandstedet som det hører til, har antagelig et krav på vern. I disse sammenhengene må det normalt være avgjørende at den etablerte og eksisterende bruken i seg selv utgjør særlig opparbeidete rettigheter, slik at et fjerningspåbud får et klart avståelseselement.

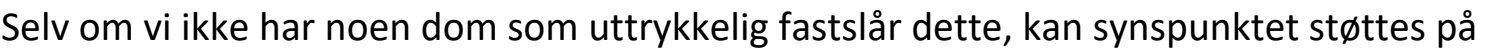
rettspraksis som gjelder inngrep i andre særrettigheter. Der noen må avgi en veirett tilliggende en grunneiendom er det lang og fast rettspraksis for at det kan utløse et krav om erstatning. ${ }^{256}$ I alle fall der veiretten har karakter av en «særrett» fordi den har et eget og annet stiftelsesgrunnlag enn bare opparbeidet bruk i tilknytning til eiendommen (for eksempel avtale), vil det gi grunnlag for vern. ${ }^{257}$ Det tilsvarende må også gjelde andre utkrystalliserte særrettigheter i tilknytning til en eiendom, for eksempel at man har fått konsesjon til å utnytte eiendommen på en bestemt måte. I rettspraksis under EMK P1-1 er det som tidligere nevnt lagt til grunn at tilbaketrekning av offentligrettslige tillatelser til å ut $\varnothing$ ve en virksomhet eller utnytte en eiendomsrett på en gitt måte riktignok faller inn under kontrollregelen, men samtidig innebærer et avståelseselement som gjør at inngrepet for å være rettmessig må være begrunnet i tungtveiende offentlige eller samfunnsmessige

\footnotetext{
Arealene i området har vært kjøpt og solgt i tillit til at de kunne utnyttes til bebyggelse, slik det generelt hadde kunnet påregnes siden før bygningslovgivningen ble innført i Kristiania i 1899, og slik reguleringsplaner senere har gitt grunnlag for. Å rive vekk det økonomiske fundament som ligger i eierposisjonen til slike eiendommer, ved at det offentlige får erverve dem til en pris som baseres på den verdi de måtte ha når utnyttelsen er begrenset ved en friområderegulering, fremstår for meg som helt uakseptabelt og i strid med vederlagsloven og med Grunnloven § 105.»

${ }^{254}$ Etter plan- og bygningsloven § 12-4 får en reguleringsplan kun virkning for fremtidige tiltak, og planen vil slik sett ikke kunne ha virkning for eksisterende bygg og innretninger.

255 Dommen på s. 1161, se også Rt-1993-321 og Rt-1993-1333 som andrevoterende viste til.

256 Rt-2014-560 avsnitt 51.

${ }^{257}$ Rt-1973-214 og (forutsetningsvis) Rt-1967-1365.
} 
hensyn. ${ }^{258}$ Det er mye som taler for at det samme bør gjelde ved rådighetsinnskrenkninger under Grl. § 105 som rammer en etablert særrett eller berettiget forventning.

Man kan godt se et slikt vern av «aksessoriske» særrettigheter og berettigede forventninger, under synsvinkelen vern av fortidige handlinger og disposisjoner under $\mathrm{Grl}$. § 97. Den som før i tiden var i sin fulle rett når han bygget en hytte, en brygge eller et båthus langs sjøen har krav på vern av sine handlinger og disposisjoner. Det samme gjelder den som gjennom senere bruk og utnyttelse, herunder gjennom erverv, nyinvesteringer og vedlikehold, har innrettet seg i henhold til en etablert og definert rett fastlagt gjennom eksisterende bruk.

Synspunktet tilsier imidlertid også at avståelsesvernet for slike aksessoriske rettsposisjoner, like lite som under Grl. § 97, kan være helt absolutt. Det er ikke her tale om frittstående rettigheter som i seg selv kan likestilles med en eiendomsrett, men om posisjoner og forventninger etablert i tilknytning til en overordnet eiendomsrett. Noen ganger kan man se det slik at det er selve eiendomsretten, som gjennom etablert bruk og innrettelse, får et positivt innhold eller en hardere substans. Tilsvarende som under Grl. § 97 tilsier dette et utgangspunkt om vern der en utkrystallisert rettsposisjon eller berettiget forventning gjennom regulering tilsidesettes, som likevel må vike der inngrepet er begrunnet $\mathrm{i}$ «sterke samfunnsmessige hensyn». ${ }^{259}$

4.4. Nærmere om betydningen av hvor vesentlig eller omfattende inngrepet er Over har vi sett at skillet mellom egentlig og uegentlig tilbakevirkning, avståelse og regulering (eller rådighetsinnskrenkning), kompliseres av at rettsposisjoner kan være sammensatte. Regulering som griper inn i berettigede forventninger eller særretter knyttet til en overordnet rettsposisjon, kan med det også få elementer av avståelse. Ethvert inngrep i en berettiget forventning eller særrett innebærer imidlertid ikke avståelse. Også her er utgangspunktet at regulering må tåles. Spørsmålet er dermed hvilke inngrep i en berettiget forventning eller særrett som kan aktualisere et skjerpet forholdsmessighetskrav.

Ofte vil det være slik at vurderingen av om reguleringen har et avståelseselement fremstår nærmest som en funksjon av konstateringen av at det foreligger en berettiget forventning. Der noen har disponert i tillit til skattefrihet og det deretter pålegges skatt, må betraktningen være at man har fått en rett til skattefritak som man så fratas. ${ }^{260}$ Det gir liten mening å se det slik at et pålegg om «litt» skatt er greit, fordi det bare utgjør en regulering av det fremtidige innholdet i den berettigede forventningen om skattefritak. Når man ikke lenger kan kreve innløsning i henhold til en avtalt og utøvd innløsningsrett, ${ }^{261}$ eller gullverdien av et lån i henhold til en gullklausul, ${ }^{262}$ har man dermed også blitt fratatt en rett som er gjenstand for en aktuell berettiget forventning. Men hva hvis man har fått konsesjon på en virksomhet mot betaling av et vederlag eller en produksjonsavgift; betyr det

\footnotetext{
258 Ovenfor pkt. 3.3.iii.

${ }^{259}$ Noe annet blir det selvfø|gelig der det kreves en overføring av rådighet til det offentlige. I så fall foreligger det ekspropriasjon.

260 Jf. Rt-2010-143 og Rt-2006-293.

${ }^{261}$ Rt-1990-284.

262 Rt-1962-369.
} 
nødvendigvis at staten er avskåret fra å kreve vederlaget beregnet på en annen måte, som er mindre gunstig for konsesjonshaveren ? $^{263}$ Eller hvis man har fått en tidsubegrenset rett til å utnytte en naturressurs; følger det nødvendigvis at staten da ikke senere kan gjøre retten tidsbegrenset? ${ }^{264}$

I noen grad kan dette ses som et spørsmål om hva man har fått en berettiget forventning om, og dermed som et spørsmål om tolkning. ${ }^{265}$ Et spørsmål i forlengelsen av dette vil gjerne måtte være om den forutsetningen, som den etterfølgende regulering griper inn i, utgjorde en vesentlig eller sentral forutsetning. Vedkommende som nok har handlet med utgangspunkt i en bestemt rettsposisjon, uten at dette utgjorde noen sentral motivasjon for handlingen, vil normalt være mindre beskyttelsesverdig. ${ }^{266}$ Men det vil også måtte ha betydning hvor vesentlig selve inngrepet er. I Phillips-dommen la Høyesterett vekt på at produksjonsavgiften i realiteten utgjorde et vederlag for retten til å utvinne petroleum, og at det var tale om en forhandlet ordning. Høyesterett anså det likevel som et moment om det forelå et vesentlig inngrep i den aktuelle rettigheten. ${ }^{267}$

Ved rådighetsinnskrenkninger under Grl. § 105 er et slikt vesentlighetskriterium blitt fremhevet som et $n \varnothing d v e n d i g$ men ikke tilstrekkelig vilkår. ${ }^{268}$ Disse sakene gjelder imidlertid regulering av fast eiendom, der eierens rådighet som utgangspunkt er negativt definert. Utgangspunktet om at regulering må tåles står dermed også særlig sterkt. Hvor det gripes inn i en positivt definert særrett eller berettiget forventning, er utgangspunktet et litt annet. Her vil den berettigede ha disponert eller innrettet seg i tillit til en bestemt rettsposisjon med et fastere definert innhold. En formell tilnærming kunne tilsi at enhver inngripen i eller innskrenkning av en slik rettighet utgjør avståelse, fordi inngrepet medfører at en bestemt del av rettigheten må avstås. Flertallet i Rt-1978-442 synes å ha bygget på et slikt syn. ${ }^{269}$

\footnotetext{
263 Rt-1985-1355.

264 Rt-2013-1345.

265 Jf. for eksempel HR-2018-1258-A, avsnitt 124: «Eierne av Gassled hadde en berettiget forventning om å kunne benytte fastsatte tariffer for allerede bookede volumer (...) Det følger av det jeg tidligere har sagt om det regulatoriske rammeverket, at eierne av Gassled ikke hadde noe rettslig grunnlag for å forvente at tariffene for fremtidige avtaler, som vår sak gjelder, ville ligge fast.»

266 Jf. slik for eksempel annenvoterende dommer Rieber-Mohn som representant for mindretallet i Rt-2006-293 avsnitt 98-99.

267 Jf. Rt-1985-1355 på s. 1374: «Etter min mening kunne staten ikke stå fritt til å skjerpe de økonomiske vilkår etter utvinningstillatelsen på denne måten. Jeg nevner at produksjonsavgiften i alminnelighet er oppfattet som vederlag for retten til utvinning. En forkortning av terminer og frister for betaling av produksjonsavgiften er også en skjerping av rettighetshavernes økonomiske vilkår. Ved vurderingen av adgangen til endringer av vilkårene på dette punkt, kan det imidlertid være et moment om endringen har noen vesentlig betydning» (min uthevning).

${ }^{268}$ Rt-2005-469 avsnitt 29, Rt-2004-1092 avsnitt 76, og Rt-1988-890 på s. 907. Se også Rt-1978-442 på s. 447 flg., Rt-1987-80 på s. 89, og Rt-1980-94 på s. 98 flg.

269 Dommen på s. 447: «Ved vedtaket ble denne - forutsetningsvis eneste - bruk av den del av sandforekomsten som ligger innen det fredede område, avskåret uten begrensning i tid. Det innebærer at på Gjerdes hånd er det tilbake bare en formell, en «tom», eiendomsrett. Det er da ikke lenger bare tale om en regulering av grunneierens rådighet over sin eiendom, men om totalt bortfall av rådigheten. For Gjerde må da - slik jeg ser det - fredningen av sandforekomsten fremstå likt med en fysisk avståelse. Nå er det formentlig klart at det ved en fysisk avståelse av en del av en eiendom, ikke kreves at avståelsen kan betegnes som
} 
Men denne tilnærmingen ble, som tidligere nevnt, uttrykkelig fraveket ved plenumsdommen i Rt-1987-80. Også den tålegrensen som er antatt å gjelde ved inngrep i opparbeidete veieller atkomstrettigheter som omtalt over, kan ses som utslag av en vesentlighetsbetraktning. ${ }^{270}$

I Rt-2004-1985 synes Høyesterett å ha lagt til grunn at loven som ga barn under 16 år fiskerett på privat grunneiendom grep inn i en form for utnyttelsesrett på eierens hånd som i utgangspunktet hadde et forholdsvis sterkt krav på vern. ${ }^{271}$ Det forelå ikke en ren negativ regulering eller rådighetsinnskrenkning, men en overføring av utnyttelsesrett fra eieren til andre. Høyesterett fant likevel at det ikke var tale om en form for rådighet eller utnyttelse der forholdet mellom eierens og allmennhetens rett var «fastlagt en gang for alle». Med andre ord var det ikke utkrystallisert noen helt klar og definert rett på eierens hånd. Retten fremholdt også som et, tilsynelatende avgjørende, argument eller moment i helhetsvurderingen at inngrepet ikke var særlig vesentlig. ${ }^{272}$

Også utfallet i strukturkvotedommen kan forstås i et slikt lys. Flertallet tilla det etter eget utsagn "stor betydning» $i$ helhetsvurderingen at rederiets tap, og dermed inngrepet i dets berettigede forventninger, ikke var særlig omfattende. ${ }^{273} \mathrm{En}$ innvending mot mindretallets resonnement er at det at tapet var lite omfattende ikke ble tillagt særlig vekt. . ${ }^{274}$ Dette handlet ikke bare om hvor stort tapet isolert sett var, som ble ansett vanskelig å tallfeste, men om hvor vesentlig inngrepet måtte fortone seg forholdsmessig til den aktuelle rettigheten. Andrevoterende viste til at tapet i Arves trafikkskole også var lite, men det er vesensforskjell på å pålegge en avgift direkte i strid med en etablert forventning om skattefrihet, og det som var situasjonen i strukturkvotedommen. Her ble de eksisterende strukturkvotene innpasset i et nytt system med tidsbegrensede kvoter, men slik at eierne fikk beholde kvotene i 25 år istedenfor de 20 årene som gjaldt for nye kvotetildelinger. Avståelsen var altså ikke umiddelbar, den lå langt frem i tid, og redernes forventninger ble søkt ivaretatt gjennom en betydelig tidskompensasjon. I et mer overordnet perspektiv kan man dermed se det slik at inngrepets preg av avståelse ikke var særlig fremtredende eller vesentlig.

\footnotetext{
"vesentlig», uansett i hvilken relasjon man vil se dette. Jeg kan imidlertid ikke se at det kan gjøre forskjell rent erstatningsmessig sett at inngrepet i dette tilfelle har formen av en rådighetsinnskrenkning når virkningen av inngrepet for grunneieren er den samme i de to situasjoner. Det innebærer at jeg ikke kan se at det her kan stilles et krav om vesentlighet om «avståelsen» er formulert som rådighetsinnskrenkning når dette ikke kreves ved fysisk avståelse. For grunneieren vil det komme ut på ett om inngrepet formuleres på den ene eller den annen måte, og hans erstatningsmessige stilling må da være den samme i begge situasjoner. Skulle det ikke være tilfelle, ville hans stilling være avhengig av lovgiverens valg av form med hensyn til den samme realitet, og det kan ikke være akseptabelt.»

270 Rt-2014-560.

271 Dommen avsnitt 52.

272 Ibid. avsnitt 60-63.

${ }^{273}$ Rt-2013-1345 avsnitt 120 og 137.

274 Dommen avsnitt 200.
} 


\section{Konklusjon}

Denne artikkelen har forsøkt å gjøre to ting. For det første har jeg argumentert for en mer prinsipporientert tilnærming til spørsmål som det ofte har vært vanlig i norsk rett å se som en fleksibel, momentbasert helhetsvurdering. For det andre har jeg anlagt en mer funksjonell eller problemorientert tilnærming til disse spørsmålene enn det som kanskje har vært vanlig i andre norske fremstillinger. Istedenfor å ta utgangspunkt i de aktuelle bestemmelsene, Grl. §§ 97 og 105 og EMK P1-1, har jeg tatt utgangspunkt i en problemstilling - vernet av rettigheter mot etterfølgende lovregulering. Siktemålet har vært dels å se de ulike bestemmelsene som byggestener i et mer helhetlig, konstitusjonelt rettighetsvern, og dels å identifisere grunnelementene av og hovedprinsippene i dette vernet. Vesentlig i dette bildet har vært et siktemål om å gi en mer integrert fremstilling av sammenhengen mellom Grunnlovens bestemmelser til beskyttelse av $\varnothing$ konomiske rettigheter og det menneskerettslige eiendomsvernet.

Artikkelens hovedkonklusjon at rettighetsvernet mot etterfølgende regulering kan formuleres som en presumsjonsbasert avveiningsnorm med to motstående utgangspunkter. Et første og grunnleggende utgangspunkt er at regulering må tåles, med et unntak for klart uforholdsmessige inngrep. Imidlertid suppleres dette av et annet og motstående utgangspunkt, som særlig aktualiseres der en etterfølgende regulering går langt i å tilsidesette en forutgående berettiget forventning eller særrett. I så fall kan man se det slik at inngrepet, selv om det har et regulatorisk siktemål, likevel får et element av avståelse (eller av direkte eller egentlig tilbakevirkning) som aktualiserer et skjerpet forholdsmessighetskrav. Under norsk rett har Høyesterett formulert dette som et krav til «sterke samfunnsmessige hensyn».

Mellom disse ytterpunktene er det en glidende overgang. Også andre momenter enn hvor omfattende inngrepet er, og hvor sterke de offentlige interesser som begrunner det er, vil kunne ha betydning. Av særlig betydning her vil for eksempel kunne være om inngrepet rammer generelt eller individuelt. Likevel er det mye som taler for at det også gjelder ulike utgangspunkter for vurderingen - ulike krav til forholdsmessighet - avhengig av hva slags rettighet det gripes inn i og hvor omfattende inngrepet er. Dette er egentlig artikkelens hovedpoeng.

\section{Litteraturliste}

Alvik, Ivar, «Grl. § 105» i Ola Mestad og Dag Michalsen, Grunnloven: Historisk kommentarutgave, Oslo 2021 (under publisering)

Alvik, Ivar og Bjørnebye, Henrik, «Om konsesjoner og konsesjonsrett» Jussens venner, Årg. 55 (2) 2020, s. 85104

Andenæs, Johs. og Fliflet, Arne, Statsforfatningen i Norge, 11. utg., Oslo 2017

Aschehoug, T. H., Norges nuværende statsforfatning, Oslo 1893

Augdahl, Per, «Noen bemerkninger om grunnlovens § 97 og § 105» Rt-1935-33

Backer, Inge Lorange, «Lovgivere og domstoler ved begynnelsen av det 21. århundre» Jussens Venner, 2006, s. 248-266

Baldersheim, Erlend, Til tingsrettens teori, Oslo 2017 
Beatty, David, The Ultimate Rule of Law, Oxford 2004

Bernt, Jan Fridtjof, og Rasmussen, Ørnulf, Frihagens forvaltningsrett Bind 1, 2. utg. Bergen 2010

Broch, Lars Oftedal, «Skjønnsmarginen i nyere praksis fra Den europeiske menneskerettsdomstol» Lov og Rett, 2005, s. 259-282

Bugge, Hans Christian, «Grunnloven § 97: En oversikt over teori og nyere rettspraksis» Jussens Venner 1999 s. 65-101

Bårdsen, Arnfinn, foredrag på Ryssdalseminaret 30. november 2017, tilgjengelig på https://www.domstol.no/globalassets/upload/hret/dokumenter/taler-og-artikler/ryssdal-seminaret-2017.pdf.

Arnfinn Bårdsen, «Norges Høyesterett, Grunnloven og menneskerettighetene» $i$ Andreas Føllesdal, Morten Ruud og Geir Ulfstein (red.), Menneskerettighetene og Norge, Universitetsforlaget 2017, s. 63-90

Castberg, Frede, Norges statsforfatning II, 3. utg. Oslo 1964

Castberg, Frede, Grunnlovens forbud mot å gi lover tilbakevirkende kraft, Oslo 1919

Fleischer, Carl August, «Grunnlovens § 97» Jussens Venner, 1975

Fleischer, Carl August, Grunnlovens grenser for lovregulert fastsetting av erstatning ved ekspropriasjon, særlig ved verdistigning som ikke skyldes grunneierens innsats, Oslo 1968

Graver, Hans Petter, Alminnelig forvaltningsrett, 4. utg. Oslo 2015

Graver, Hans Petter, «Dømmer Høyesterett i siste instans?» Jussens Venner, 2002, s. 263-281

Hagstrøm, Viggo og Stenvik, Are, Erstatningsrett, Oslo 2015

Harbo, Tor-Inge, «Forholdsmessighet i kontekst: forholdsmessighetsvurderinger i norsk forvaltnings- og forfatningsrett» Lov og Rett, 2015, s. 513-535

Harris, O'Boyle and Warbrick, Law of the European Convention on Human Rights, 4. utg., Oxford 2018

Harris, J. W., Property \& Justice, Oxford 2001

Holmøyvik, Eirik, «Prøvingsrett og tilbakeverknadsforbod: Borthen-dommen i Rt-1996-1415 og rettsutviklinga», i Rettsavklaring og rettsutvikling: Festskrift til Tore Schei, Universitetsforlaget 2016 s. 210-242

Høgberg, Benedikte Moltumyr, «Tilbakevirkningsforbudet som rettskildeprinsipp» i Alf Petter Høgberg og Jørn Øyrehagen Sunde (red.), Juridisk metode og tenkemåte, Universitetsforlaget 2019, s. 562-567

Høgberg, Benedikte Moltumyr, «Betydningen av internasjonale rettskilder i norsk statsforfatningsrett» $i$ Andreas Føllesdal, Morten Ruud og Geir Ulfstein (red.), Menneskerettighetene og Norge, Oslo 2017, s. 215-227

Høgberg, Benedikte Moltumyr, «Hvordan samfunnet har påvirket tolkningen av Grunnloven §§ 97 og 105» $i$ Eirik Holmøyvik (red.), Tolkingar av Grunnlova: Om forfatningsutviklinga 1814-2014, Oslo 2013, s. 368-403

Høgberg, Benedicte Moltumyr, «Grunnloven § 97 etter plenumsdommen i Rt-2010-143 (Rederiskattesaken)» Tidsskrift for rettsvitenskap, 2010, s. 694-744

Høgberg, Benedikte Moltumyr, Forbud mot tilbakevirkende lover, Oslo 2010

Innjord, Frode, «Forholdet mellom Grunnloven § 97 og § 105» Tidsskrift for eiendomsrett, 2008 Nr. 1, s. 11-27

Jacobs, White and Ovey, The European Convention on Human Rights, 6. utg (ved Bernadette Rainey, Elizabeth Wicks og Clare Ovey), Oxford 2014

Kierulf, Anine, 'Er internasjonale menneskerettigheter en relevant rettskilde ved grunnlovstolkning?' Retfærd, 2011 nr. 1, s. 23-48

Knoph, Ragnar, Rettslige standarder, Oslo 1948

Langeland, Nils Rune, Siste ord - Høyesterett i norsk historie 1814 - 1965, Bind 1, Oslo 2005 
Lie, M. H., «Betenkning angående grunnlovens §§ 97 og 105 og om domstolenes myndighet til å prøve loves indre gyldighet» $i$ St. forh. (1923) Dok nr. 13

Morgenstierne, Bredo, Lærebog i den norske Statsforfatningsret, 2. utg., Oslo 1909

North, Douglas C. og Thomas, Robert Paul, The Rise of the Western World: A New Economic History, Cambridge 1973

Nyhus, Håkon Christian, «Høyesterett og EMD - samme skjønnsmargin?» Lov og Rett, 2016, s. 364-390

Pellonpää, Matti, «Dialog mellom Den europeiske menneskerettsdomstol og nasjonale domstoler» Det 40. nordiske juristmøte i Oslo 2014, tilgjengelig på http://nordiskjurist.org/wp-

content/uploads/2014/07/referent19.pdf;

Schlatter, Richard, Property - the History of an Idea, London 1951

Sigron, Maya, Legitimate expectations under Article 1 of Protocol No. 1 to the European Convention on Human Rights, Cambridge 2014

Skeie, Jon, «Grundloven og Handelslovgivningen», Oslo 1916

Skeie, Jon, «Om statens pligt til at yde erstatning, naar lovgivningen indskrænker eller ophæver en tidligere adgang til salg eller skjænkning av alkoholholdige drikkevarer eller stiller nye vilkaar for utøvelsen av denne virksomhed», bilag 4 til alkoholkommisionens indstilling, Kristiania 1915

Skoghøy, Jens Edvin A., «Forbud mot tilbakevirkende lovgivning» Lov og Rett, 2011, s. 255-282

Smith, Eivind, Konstitusjonelt demokrati, 4. utg., Oslo 2009

Smith, Eivind, «Grunnloven § 97: En eller to hovedregler?» Lov og Rett (2013) s 488-499

Solheim, Stig, Eiendomsbegrepet i Den Europeiske menneskerettskonvensjon, Oslo 2010

Solheim, Stig, «Domstolskontroll med lov på det økonomiske området - lovgivers vurdering av lovens grunnlovsmessighet», Tidsskrift for rettsvitenskap, 2014, s. 1-48

Thorson, Bjarte, Erstatningsrettslig vern for rene formuestap, Oslo 2011

Tverberg, Arnulf, «§ 89» i Ola Mestad og Dag Michalsen, Grunnloven: Historisk kommentarutgave, Oslo 2021 (under publisering)

Tverberg, Arnulf, «Det graderte grunnlovsvernet ved tolking av Grunnloven og prøving av lovers grunnlovmessighet» i Eirik Holmøyvik (red.), Tolkingar av Grunnlova, Oslo 2013, s. 256-303

$\emptyset$ yrehagen Sunde, Jørn, Høgsteretts historie 1965-2015, Bergen 2015

Aall, Jørgen, Rettsstat og menneskerettigheter, 5. utg., Bergen 2018, s. 556 